PNNL-16424, Rev. 1

Pacific Northwest National Laboratory

Operated by Battelle for the U.S. Department of Energy

\section{Treatability Test Plan for an In Situ Biostimulation Reducing Barrier}

\author{
M. J. Truex \\ V. R. Vermeul \\ P. E. Long \\ F. J. Brockman \\ M. Oostrom \\ S. Hubbard \\ R. C. Borden \\ J. S. Fruchter
}

October 2007 


\title{
DISCLAIMER
}

This report was prepared as an account of work sponsored by an agency of the United States Government. Neither the United States Government nor any agency thereof, nor Battelle Memorial Institute, nor any of their employees, makes any warranty, express or implied, or assumes any legal liability or responsibility for the accuracy, completeness, or usefulness of any information, apparatus, product, or process disclosed, or represents that its use would not infringe privately owned rights. Reference herein to any specific commercial product, process, or service by trade name, trademark, manufacturer, or otherwise does not necessarily constitute or imply its endorsement, recommendation, or favoring by the United States Government or any agency thereof, or Battelle Memorial Institute. The views and opinions of authors expressed herein do not necessarily state or reflect those of the United States Government or any agency thereof.

\author{
PACIFIC NORTHWEST NATIONAL LABORATORY \\ operated by \\ BATTELLE \\ for the \\ UNITED STATES DEPARTMENT OF ENERGY \\ under Contract DE-AC05-76RL01830 \\ Printed in the United States of America \\ Available to DOE and DOE contractors from the \\ Office of Scientific and Technical Information, \\ P.O. Box 62, Oak Ridge, TN 37831-0062; \\ ph: (865) 576-8401 \\ fax: $(865) 576-5728$ \\ email: reports@adonis.osti.gov \\ Available to the public from the National Technical Information Service, \\ U.S. Department of Commerce, 5285 Port Royal Rd., Springfield, VA 22161 \\ ph: (800) 553-6847 \\ fax: (703) 605-6900 \\ email: orders@ntis.fedworld.gov \\ online ordering: http://www.ntis.gov/ordering.htm
}

This document was printed on recycled paper.

$(9 / 2003)$ 
PNNL-16424, Rev. 1

\title{
Treatability Test Plan for an In Situ Biostimulation Reducing Barrier
}

\author{
M. J. Truex \\ V. R. Vermeul \\ P. E. Long \\ F. J. Brockman \\ M. Oostrom \\ S. Hubbard \\ R. C. Borden \\ J. S. Fruchter
}

October 2007

Prepared for

the U.S. Department of Energy

under Contract DE-AC05-76RL01830

Pacific Northwest National Laboratory

Richland, Washington 99352 


\section{Summary}

The U.S. Department of Energy has initiated a new approach to develop and integrate innovative technologies coupled to existing baseline planning options to accelerate cleanup of chromium in the 100 Areas located at the Hanford Site. The development and testing of new innovative technologies will provide supplemental treatment upgradient of the In Situ Redox Manipulation (ISRM) barrier by directly treating chromium and other oxidizing species in groundwater (i.e., nitrate and dissolved oxygen), and thereby potentially increasing the longevity of the ISRM barrier.

As part of that effort, scientists at Pacific Northwest National Laboratory will perform treatability tests designed to demonstrate that in situ biostimulation can be applied to help meet cleanup goals in the $100-\mathrm{D}$ Area. In addition to remediating a portion of the plume and demonstrating reduction of electron acceptors in the plume, the data from this test will provide the U.S. Department of Energy with valuable information for designing a full-scale bioremediation system to apply at this and other chromium plumes at the Hanford Site. 


\section{Acronyms and Abbreviations}

ARAR

bgs

CERCLA

DOE

$\mathrm{EBF}$

Eh

Ecology

EPA

ERDF

GMS

HPLC

IC

ICP

ISRM

MS

NEPA

OES

ORP

PNNL

PVC

QA

QAPP

RCRA

RL

ROD

SAP

SBMS

$\mathrm{T}$

TOC

WAC applicable or relevant and appropriate requirement(s)

below ground surface

Comprehensive Environmental Response, Compensation, and Liability Act

U.S. Department of Energy

electromagnetic borehole flow meter

oxidation-reduction

Washington State Department of Ecology

U.S. Environmental Protection Agency

Environmental Restoration Disposal Facility

groundwater modeling system

high-pressure liquid chromatography

ion chromatography

inductively coupled plasma

in situ redox manipulation

mass spectrometer

National Environmental Policy Act of 1969

optical emission spectrometry

oxidation-reduction potential

Pacific Northwest National Laboratory

polyvinyl chloride

quality assurance

Quality Assurance Project Plan

Resource Conservation and Recovery Act

U.S. Department of Energy, Richland Operations Office

record of decision

Sampling and Analysis Plan

Standards Based Management System

temperature

total organic carbon

Washington Administrative Code or waste acceptance criteria 


\section{Contents}

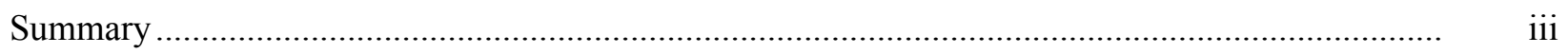

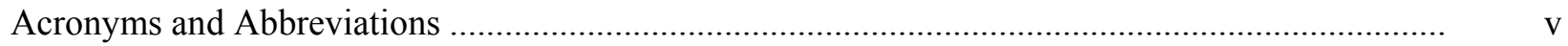

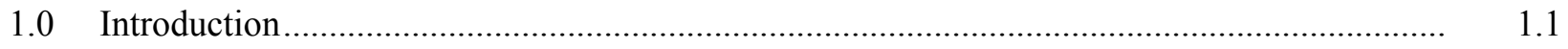

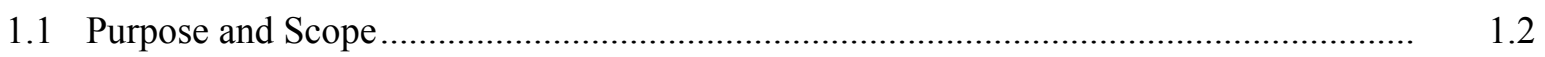

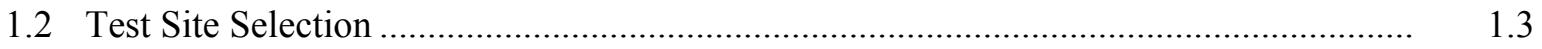

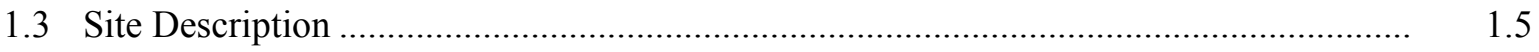

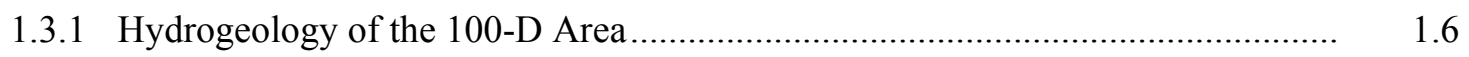

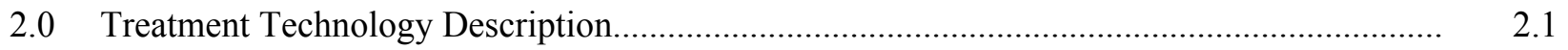

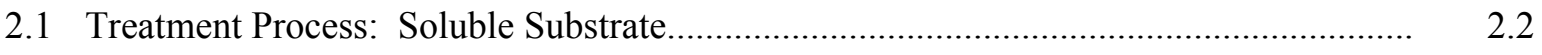

2.2 Treatment Process: Immiscible Substrate ................................................................. 2.3

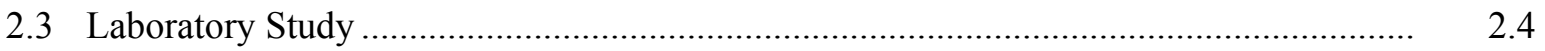

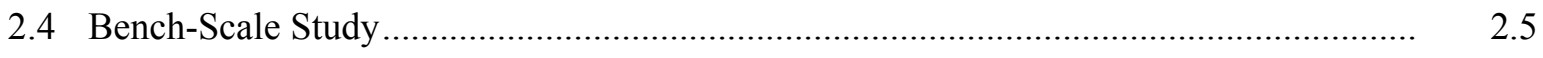

3.0 Performance and Data Quality Objectives ....................................................................

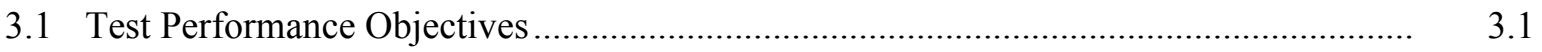

3.2 Data Quality Objectives..................................................................................

3.3 Comparison Levels .............................................................................................

4.0 Compliance with Applicable or Relevant and Appropriate Requirements ............................. 4.1

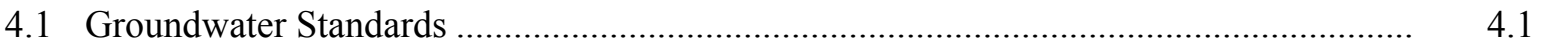

4.2 Columbia River Protection Standards ....................................................................... 4.2

4.3 Cultural and Ecological Resource Protection Standards ...............................................

4.4 Waste and Wastewater Management Standards .............................................................

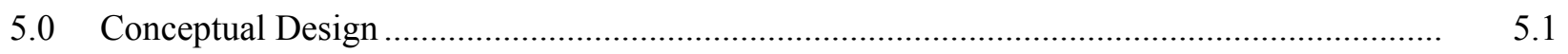

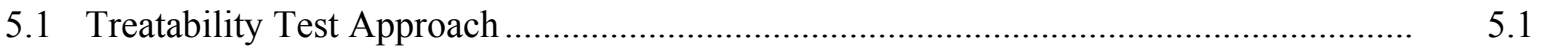

5.2 Treatability Test Activities ............................................................................... 5.2

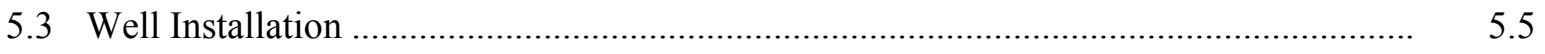

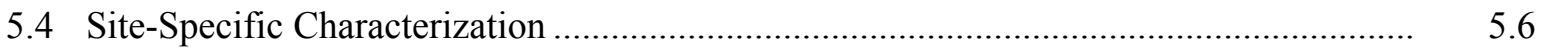

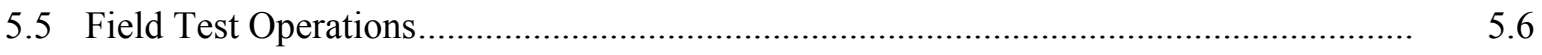

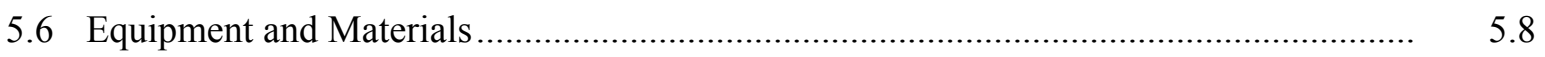

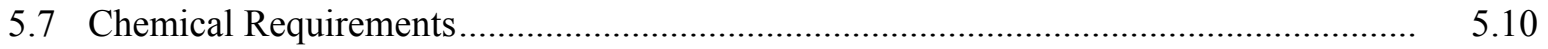

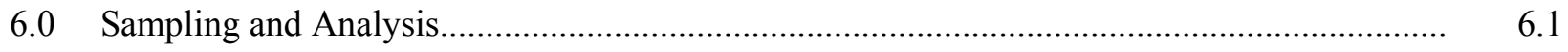

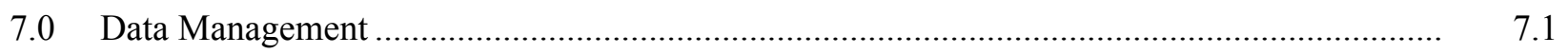

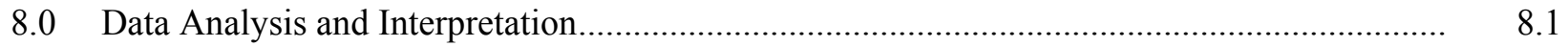

8.1 Laboratory- and Bench-Scale Performance ............................................................ 8.1

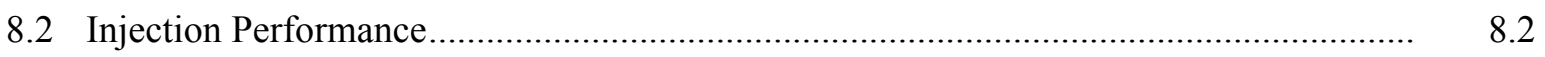

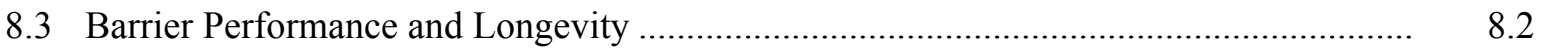

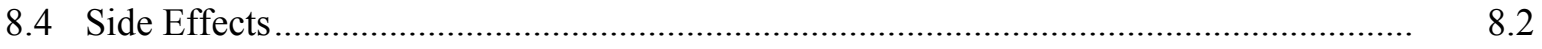




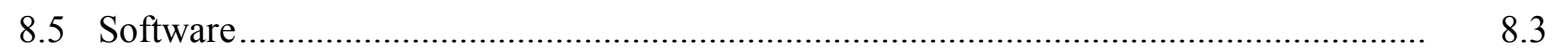

8.5.1 Description of Software for the Project......................................................... 8.3

8.5.2 Groundwater Modeling System Software Requirements ................................... 8.3

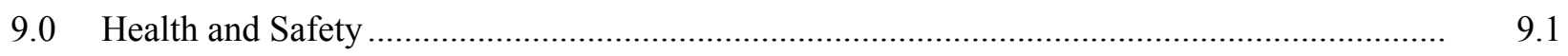

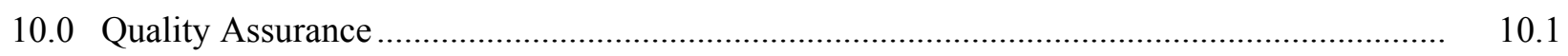

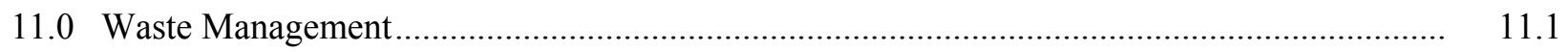

12.0 National Environmental Policy Act Values ................................................................ 12.1

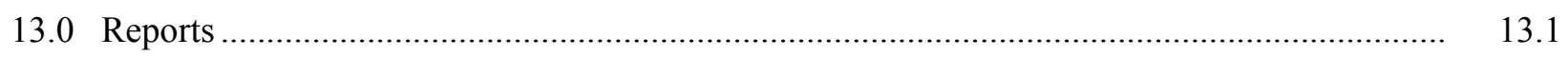

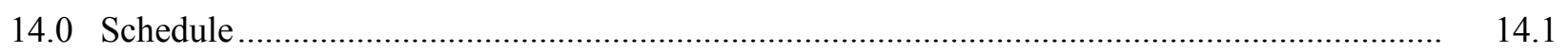

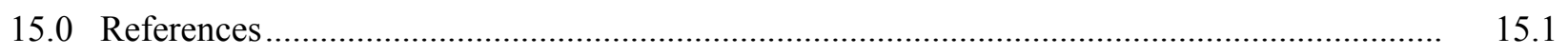

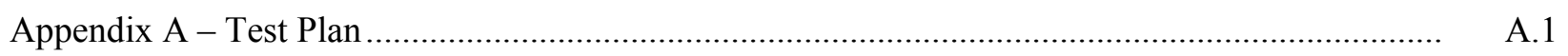

Appendix B - Test Plan Summary .................................................................................... B. 1

Appendix C - Use of Geophysical Methods for Monitoring Amendment Distribution:

Appendix D - Drilling and Well Completion Plan................................................................. D. 1

\section{Figures}

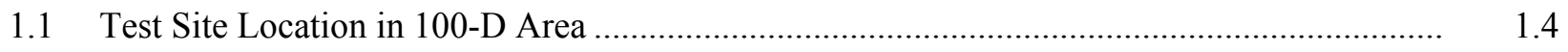

1.2 Chromium Plume Contours at 100-D Area...................................................................... 1.5

1.3 Indication of Chromium Distribution in Groundwater from a Recent Investigation

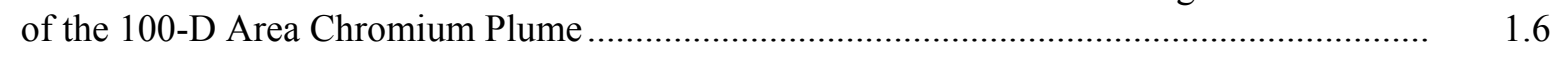

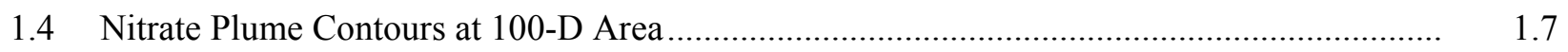

1.5 100-D Area Hydrogeologic Cross Section of the Uppermost Aquifer ................................. 1.8

5.1 Conceptual Layout of Test Cells (to be Finalized During the Design Process)...................... 5.2

5.2 Conceptual Test Equipment Schematic ......................................................................... 5.7

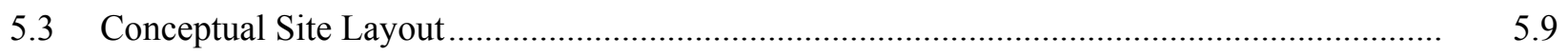

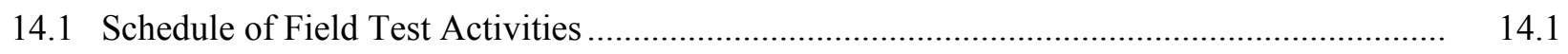

\section{Tables}

3.1 Biostimulation Barrier Key Decisions …...................................................................... 3.2

5.1 Chemical Additives for the Treatability Test ................................................................. 5.10

6.1 Groundwater Chemistry Sampling Requirements ........................................................ 6.1

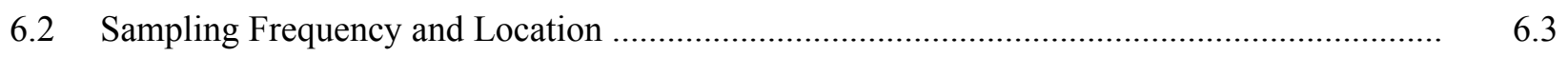

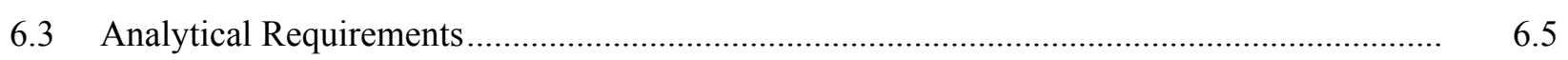

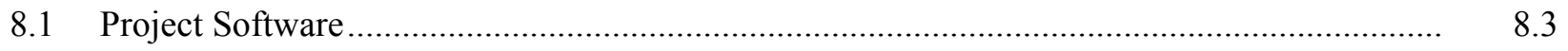

8.2 Software Risk Management Description ....................................................................... 8.4

11.1 Spill Kits and Spill Control Equipment ................................................................. 11.1 


\subsection{Introduction}

The U.S. Department of Energy (DOE) has initiated a new approach to develop and integrate innovative technologies coupled to existing baseline-planning options to accelerate cleanup of chromium in the 100 Areas at the Hanford Site. Development and testing of new innovative technologies will provide supplemental treatment upgradient of the In Situ Redox Manipulation (ISRM) barrier by directly treating chromium and other oxidizing species in groundwater (i.e., nitrate and dissolved oxygen), thereby potentially increasing the longevity of the ISRM barrier.

The approach is to integrate in situ biostimulation, an innovative technology, with existing remediation alternatives for the 100-D Area. The biostimulation technology will immobilize chromium mass and reduce nitrate and dissolved oxygen concentrations in the southwestern plume upgradient of the ISRM barrier. A previous pilot-scale experiment at the $100-\mathrm{H}$ Area, funded by DOE, has shown that injection of an organic substrate (polylactate) can stimulate indigenous microorganisms to reduce chromate and nitrate and deplete dissolved oxygen in the aquifer. This treatability test plan describes treatability testing for applying in situ biostimulation as a potential low-cost, long-lasting means to treat chromate, nitrate, and oxygen over a large areal extent upgradient of the ISRM barrier.

This treatability test plan supports the accelerated cleanup by performing a field-scale treatability test for bioreduction of chromate, nitrate, and dissolved oxygen. In addition to remediating a portion of the plume and demonstrating reduction of electron acceptors in the plume, the data from this test will be valuable for designing a full-scale bioremediation system for potential application at this and other chromium plumes at the Hanford Site.

Limited field investigations and a qualitative risk assessment performed in the 100-HR-3 Operable Unit have established that hexavalent chromium is a groundwater contaminant of concern for ecological receptors in the Columbia River (DOE 1994). An interim action Record of Decision (ROD) (EPA 1999) was issued for the groundwater 100-HR-3 Operable Unit in 1996 to address the chromium plume that was entering the Columbia River in the 100-D and 100-H Areas at levels exceeding the U.S. Environmental Protection Agency's (EPA) ambient water quality criteria for protection of freshwater aquatic organisms (11 parts per billion [ppb]). The preferred alternative action in the interim action ROD was pump-andtreat technology, using ion exchange columns as the treatment technology. The 100-D Area aquifer has the highest concentrations of dissolved chromium on the Hanford Site (potentially $>10000 \mathrm{ppb}$ ). Samples from aquifer tubes located near the shore of the Columbia River contain chromium concentrations at levels greater than $200 \mathrm{ppb}(>20$ times the aquatic standard, and $>10$ times the remedial action goal for protecting ecological resources [i.e., $22 \mathrm{ug} / \mathrm{L}])$.

Chromium at varying concentrations was introduced to the soil and groundwater in the 100 Areas from a number of sources. The largest plumes were caused by disposing reactor coolant to surface basins. Sodium dichromate was added to cooling water to inhibit corrosion in the reactor cooling system (HAPO 1953), resulting in a concentration of $\sim 700 \mathrm{ug} / \mathrm{L}$ of dissolved chromium in the coolant effluent. After passing through the reactor, the coolant flowed through large-diameter underground pipes to retention basins for thermal and radioactive cooling prior to discharge to the Columbia River. When fuel cladding ruptures occurred, trenches and cribs were used to dispose of the radiologically contaminated cooling water. Cooling system piping and retention basins leaked large volumes to the ground, creating substantial groundwater mounds and raising the water table over large portions of each reactor area 
(Brown 1963). For example, the groundwater mound in the 100-D Area was 3 to $6 \mathrm{~m}$ higher than the ambient water table. These mounds dissipated following cessation of reactor operations, but some residual amount of chromium-contaminated moisture likely remained in the overlying vadose zone.

Higher concentrations of chromium $(>700 \mathrm{ug} / \mathrm{L})$ were also introduced to the soil and migrated downward to groundwater through relatively localized areas. Leaks and spills of concentrated sodium dichromate stock solutions likely occurred where it was stored and handled. Chromic acid was used to decontaminate reactor equipment and was then disposed to French drains, cribs, and trenches.

In addition to the 100-D Area chromium plumes, nitrate and dissolved oxygen are present in the groundwater treated by the ISRM barrier. Because these species consume reductive capacity, they impact the longevity of the ISRM barrier (Szecsody et al. 2005). Of these oxidized species, Cr(VI) is the easiest to reduce (followed by oxygen and then nitrate) and represents the smallest oxidizing capacity. For example, $8 \mathrm{mg} / \mathrm{L}$ dissolved oxygen is the equivalent of about $40 \mathrm{mg} / \mathrm{L} \mathrm{Cr}(\mathrm{VI})$, a much higher concentration of $\mathrm{Cr}(\mathrm{VI})$ than is present in the 100-D Area groundwater (Szecsody et al. 2005). Thus, any remedial approach that reduces dissolved oxygen and nitrate concentrations upgradient of the ISRM barrier will increase barrier longevity.

Although the primary purpose of the ISRM barrier was to reduce the amount of hexavalent chromium entering the Columbia River, additional action is required to 1) address the high-concentration portion of the chromium plume upgradient of the ISRM barrier, and 2) increase the longevity of the barrier, portions of which have been exhibiting signs of premature breakdown. The proposed method to accomplish this is to use in situ biostimulation to reduce hexavalent chromium and other oxidizing species (i.e., nitrate and dissolved oxygen), and establish a permeable reactive barrier that will continue to treat chromium, nitrate, and dissolved oxygen under natural groundwater flow conditions. Biostimulation is expected to have a low probability of geochemical impact while achieving the desired goal of eliminating the high concentrations of chromate, nitrate, and dissolved oxygen upgradient of the ISRM barrier. Bioremediation can also be designed to sustain reduction of groundwater species over relatively long time periods via slowrelease substrates, buildup of biomass, and/or relatively inexpensive re-injection of substrates.

\subsection{Purpose and Scope}

As part of the integrated approach for the chromium plume in the 100-D Area, the overall goal for treatment of chromate, nitrate, and dissolved oxygen upgradient of the ISRM barrier is to reduce the electron acceptor flux to the ISRM barrier. This approach will extend the lifetime of the barrier, thereby reducing the discharge of hexavalent chromium to the Columbia River by immobilizing chromium in the aquifer before it reaches the Columbia River. To achieve this goal, chromate, nitrate, and dissolved oxygen concentrations need to be reduced over a relatively large areal extent $(\sim 500$ linear $\mathrm{m}$ of reactive barrier). Due to the potential for continuing chromate and nitrate sources, upgradient dissolved oxygen and a relatively long $(700-\mathrm{m})$ chromate plume length, the upgradient treatment would also need to be effective over a long period of time (tens of years).

This work plan outlines the approach for a treatability test to design and demonstrate that in situ biostimulation can be applied to meet the goals for upgradient treatment in the 100-D Area. The overall objectives of the treatability test are as follows:

- Demonstrate field-scale reduction of chromate, nitrate, and dissolved oxygen concentrations and the longevity of treatment to evaluate the effectiveness of the process at full scale. 
- Demonstrate field-scale application of biostimulation to evaluate implementability of the process at full scale.

- Determine the number of wells, type of substrate, operational strategy, and longevity for biostimulation such that costs for full-scale application can be effectively estimated.

Key biostimulation design parameters associated with these objectives include 1) the radius of influence for injection of the substrate, 2) mass of substrate that can be injected, 3) biomass yield for the substrate, 4) bioreduction yield for chromate, nitrate, and oxygen for the substrate and biomass, and 5) the rate of substrate and biomass depletion. Site-specific hydrogeological characteristics also influence the biostimulation design parameters and need to be determined to conduct the treatability test and for use in determining how the process will be designed for full-scale application.

\subsection{Test Site Selection}

The treatability test design will consider how to evaluate the key implementation issues for the biostimulation approaches selected for field-scale treatability testing within the context of the site setting. To select a site suitable for field-scale testing of technology, several site-selection criteria were developed for screening potential test site locations (Figure 1.1). Site-selection criteria included the following:

- Minimize Columbia River stage variation impacts on treatability test monitoring

- Minimize the impacts on performance monitoring of the zero valent iron amendment treatability study being conducted at the ISRM barrier location

- Favorable hydrogeologic conditions for a pilot-scale field test (relatively thin aquifer, avoids any known areas of high heterogeneity, minimizes variability in groundwater flow direction, etc.)

- Locate site so that there is a constant upgradient concentration of oxidizing species over the life of the treatability study

- No site-access constraints.

Based on the above selection criteria, a location just downgradient of existing monitoring well 199-D5-40 (hereafter, referred to as D5-40) was selected as the preferred location. Although this location is not within the highest concentration portion of the chromium plume (Figure 1.2), trend data at this location indicate that chromium concentrations (200-400 ppb) are sufficient to meet treatability test objectives. More recent investigation of the 100-D Area chromium plume provide additional detail in the high-concentration portion of the plume, although these data have not been published at the time this test plan was prepared (Figure 1.3). As shown in Figure 1.4, this location is also well within the 45-mg/L-nitrate contour. The selected test-site location is approximately $300-\mathrm{m}$ upgradient of the existing ISRM barrier so that the test can be effectively monitored without interference from the ISRM barrier, and activities at the biostimulation test site should not impact performance monitoring of other technology demonstration efforts (e.g., zero valent iron injections at the ISRM barrier). Based on pump-and-treat system capture zone analysis (DOE 2006), activities near well D5-40 will not affect well D5-39, the closest pumping well. 


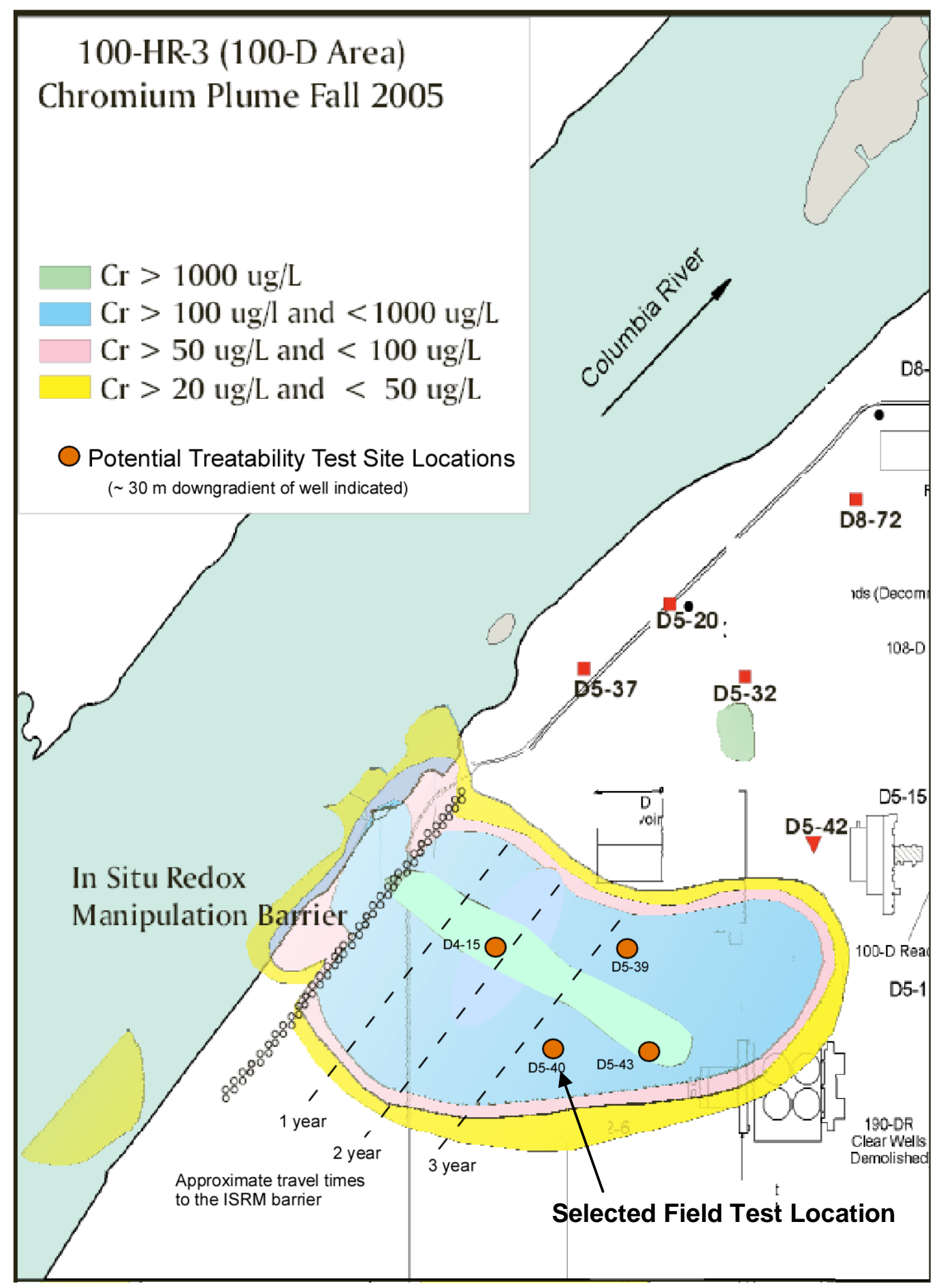

Figure 1.1. Test Site Location in 100-D Area

Hydrogeologic conditions were comparable for all sites evaluated, so these criteria did not eliminate consideration of any potential locations. Site-access constraints were identified for locations near D5-39 and D5-43 associated with the existing pump-and-treat system and ongoing source area investigations, respectively. 


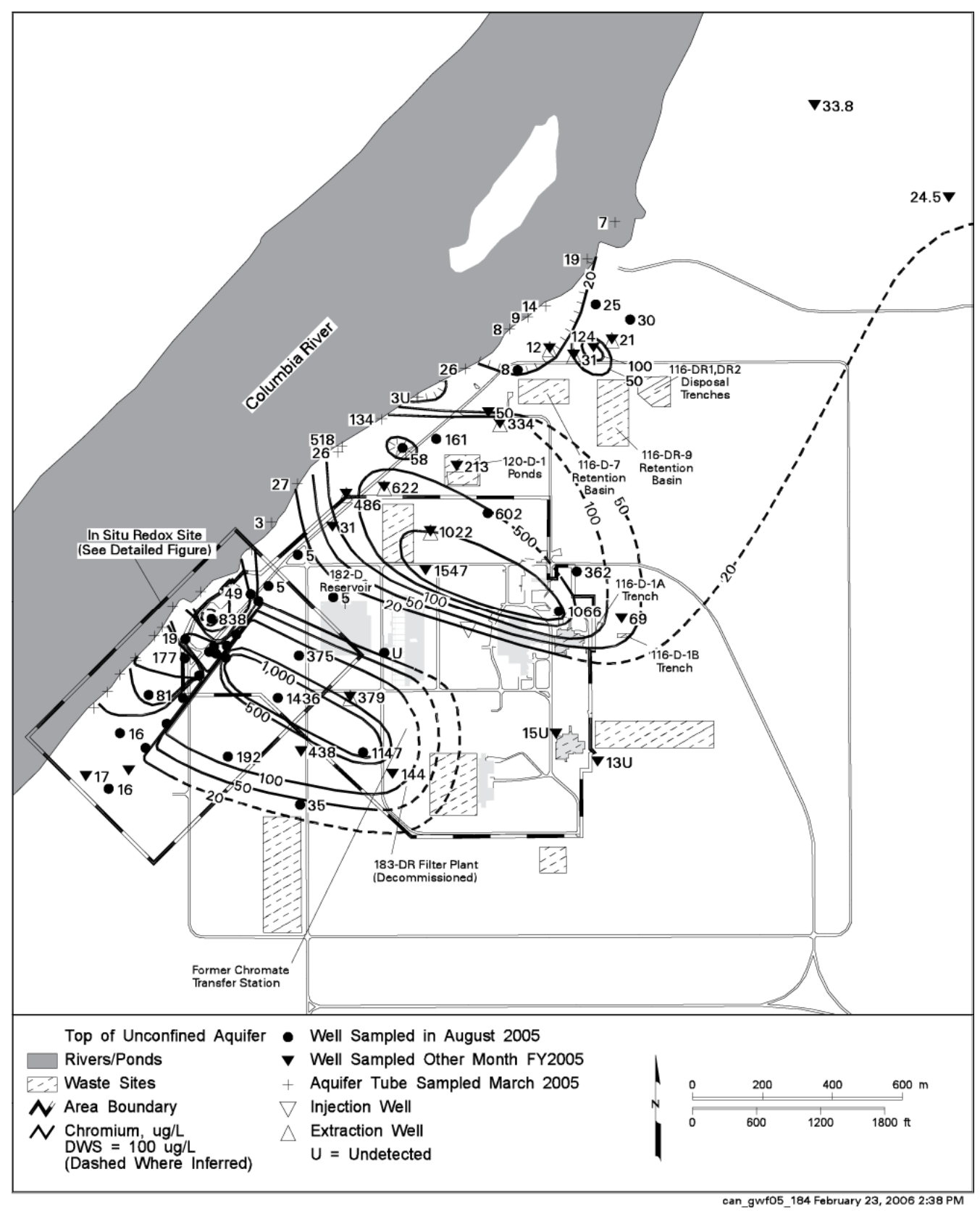

Figure 1.2. Chromium Plume Contours at 100-D Area

\subsection{Site Description}

The treatability test site is located in the southwestern portion of the 100-D Area. Groundwater beneath the 100-D Area, the 100-H Area, and the intervening 600 Area is part of the groundwater 100-HR-3 Operable Unit. Because of the nature and extent of past practices, chromium contamination is present in groundwater in concentrations exceeding regulatory limits and has been determined to be a contaminant of potential concern (DOE 1993). The 100-D Area is a focal point for groundwater remediation. 


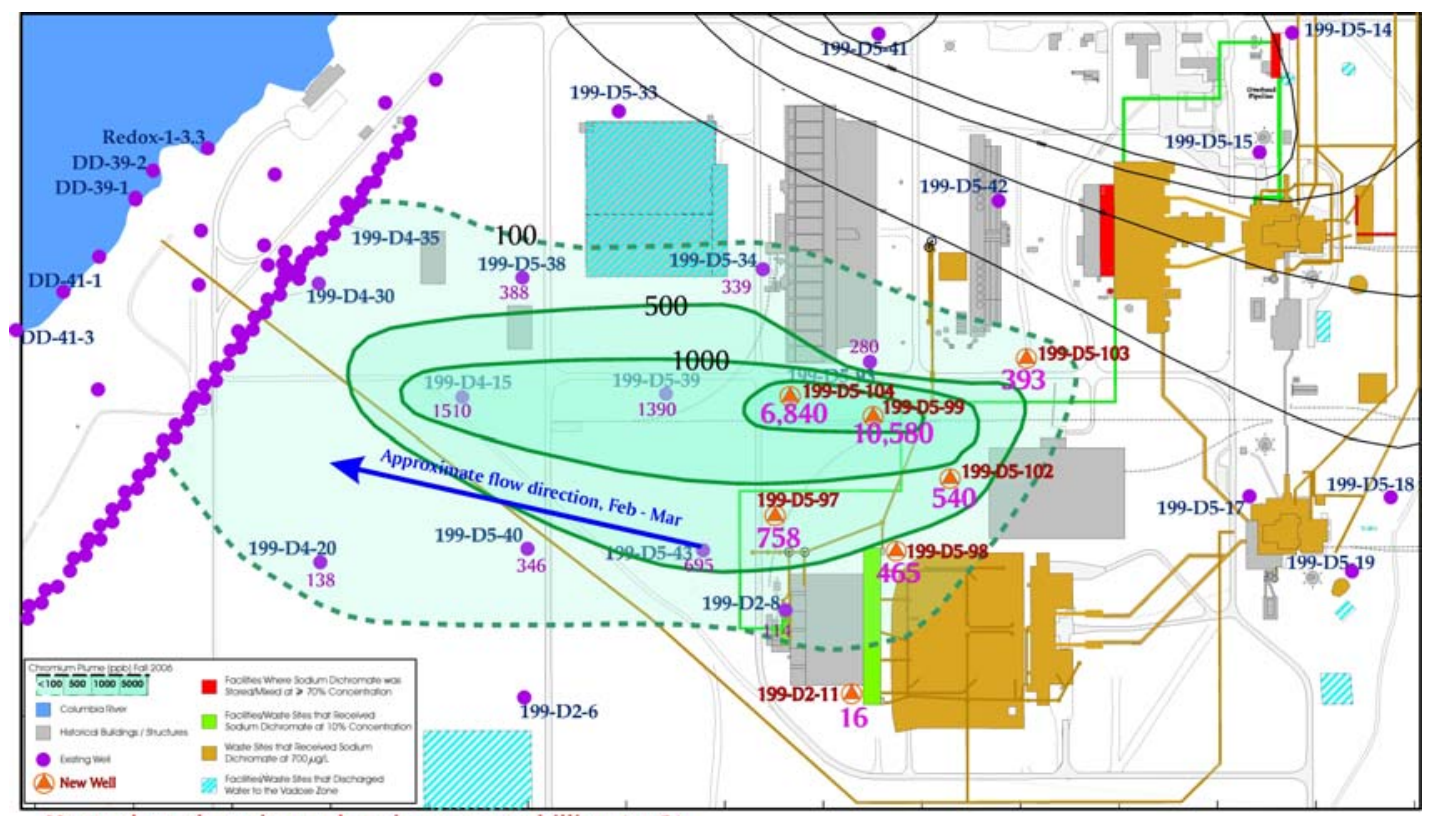

Hexavalent chromium values in parts per billion (ug/L)

Figure 1.3. Indication of Chromium Distribution in Groundwater from a Recent Investigation of the 100-D Area Chromium Plume (personal communication, Scott Petersen, May 3, 2007)

\subsubsection{Hydrogeology of the 100-D Area}

The general hydrogeologic setting of the groundwater 100-HR-3 Operable Unit (encompassing the 100-D and 100-H Areas) is described in Lindsey and Jaeger (1993) and summaries of the conceptual site models for groundwater contamination in each of these areas are presented in Peterson et al. (1996). The unsaturated (vadose) zone in the 100-D Area lies in the Hanford formation and the upper portion of the Ringold Formation (Figure 1.4). The unconfined aquifer is composed of sandy gravel to silty sandy gravel, $\sim 3$ to $9 \mathrm{~m}$ thick, which corresponds to Ringold Formation Unit E. Depth to the water table ranges from less than $1 \mathrm{~m}$ near the river to $\sim 25 \mathrm{~m}$ farther inland. The base of the unconfined aquifer is a fine-grained silty sand to clay overbank interval, designated the Ringold Formation Upper Mud Unit, which is $\sim 15-\mathrm{m}$ thick and generally dips to the west. The deeper Ringold Formation is believed to comprise more layers of clay, silt, and sand based on interpolations between wells elsewhere in the 100 Areas (Hartman 1999).

In the 100-D Area, chromium is the major contaminant of concern in groundwater and flows toward the Columbia River from multiple source areas through the uppermost unconfined aquifer. At the proposed test site location, the unconfined aquifer is contained within the lower Ringold Formation Unit $\mathrm{E}$ and is approximately 6.8 to $5.8 \mathrm{~m}$ thick (depending on fluctuations occurring in the elevation of the Columbia River); the water table is $\sim 25 \mathrm{~m}$ below ground surface (bgs). Groundwater in the unconfined aquifer generally flows northwest and discharges into the Columbia River. The estimated groundwater flow velocity is approximately $0.3 \mathrm{~m}$ /day based on measured hydraulic gradients, with an average hydraulic conductivity of $16.5 \mathrm{~m}$ /day obtained from hydraulic tests conducted at the ISRM test site. Physical property analyses (porosity, bulk density, and particle size distribution by sieve analysis) were also conducted on 15 split tube samples collected during drilling of ISRM wells. Particle size ranged from $65 \%$ to $85 \%$ gravel, $14 \%$ to $31 \%$ sand, and less than $6 \%$ fines (silt/clay). Porosity ranged from $5 \%$ to $23 \%$ with a mean of $14 \%$. Bulk density ranged from 2.1 to 2.4 with a mean of $2.3 \mathrm{~g} / \mathrm{cm}^{3}$ (Williams et al. 2000). 


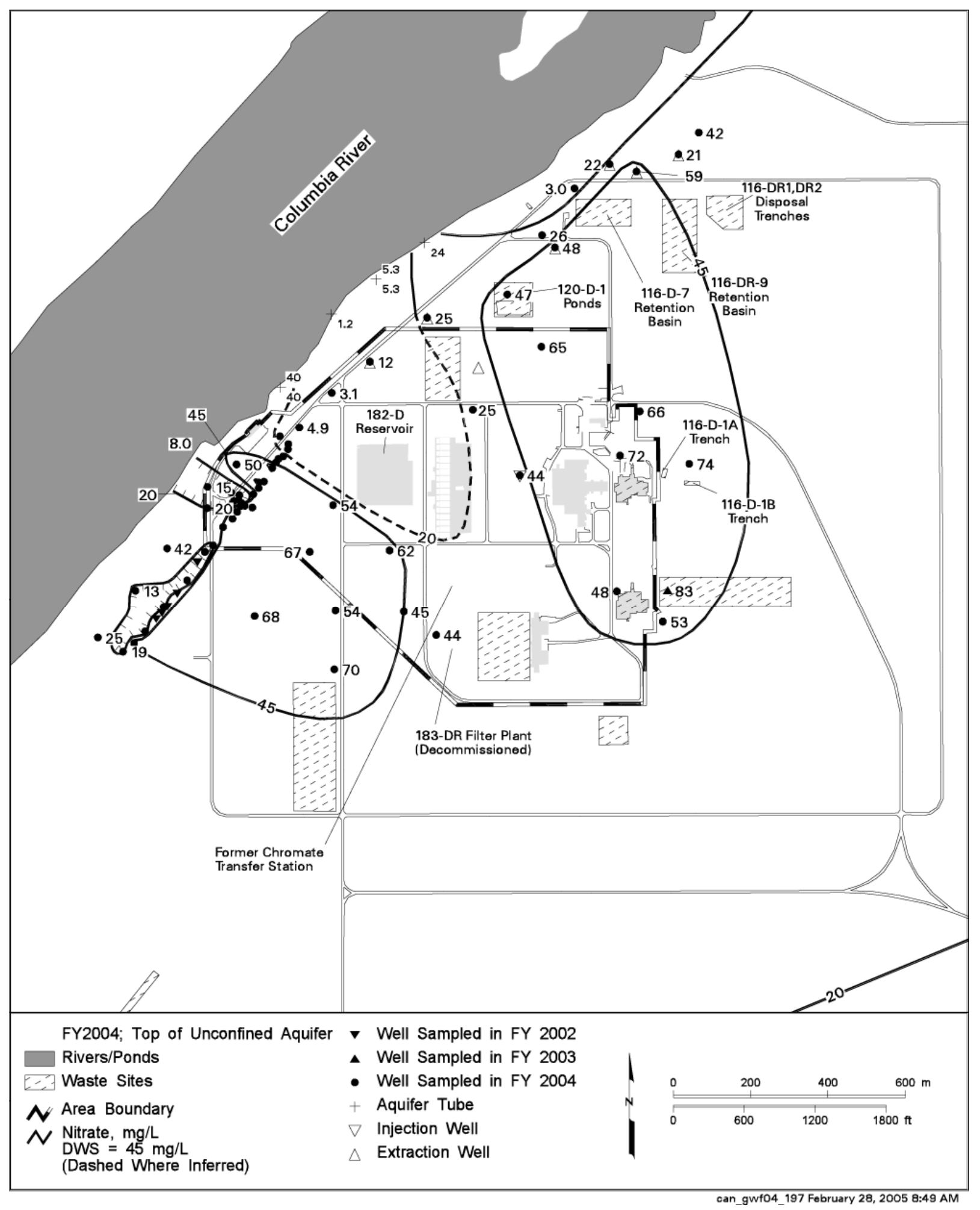

Figure 1.4. Nitrate Plume Contours at 100-D Area 


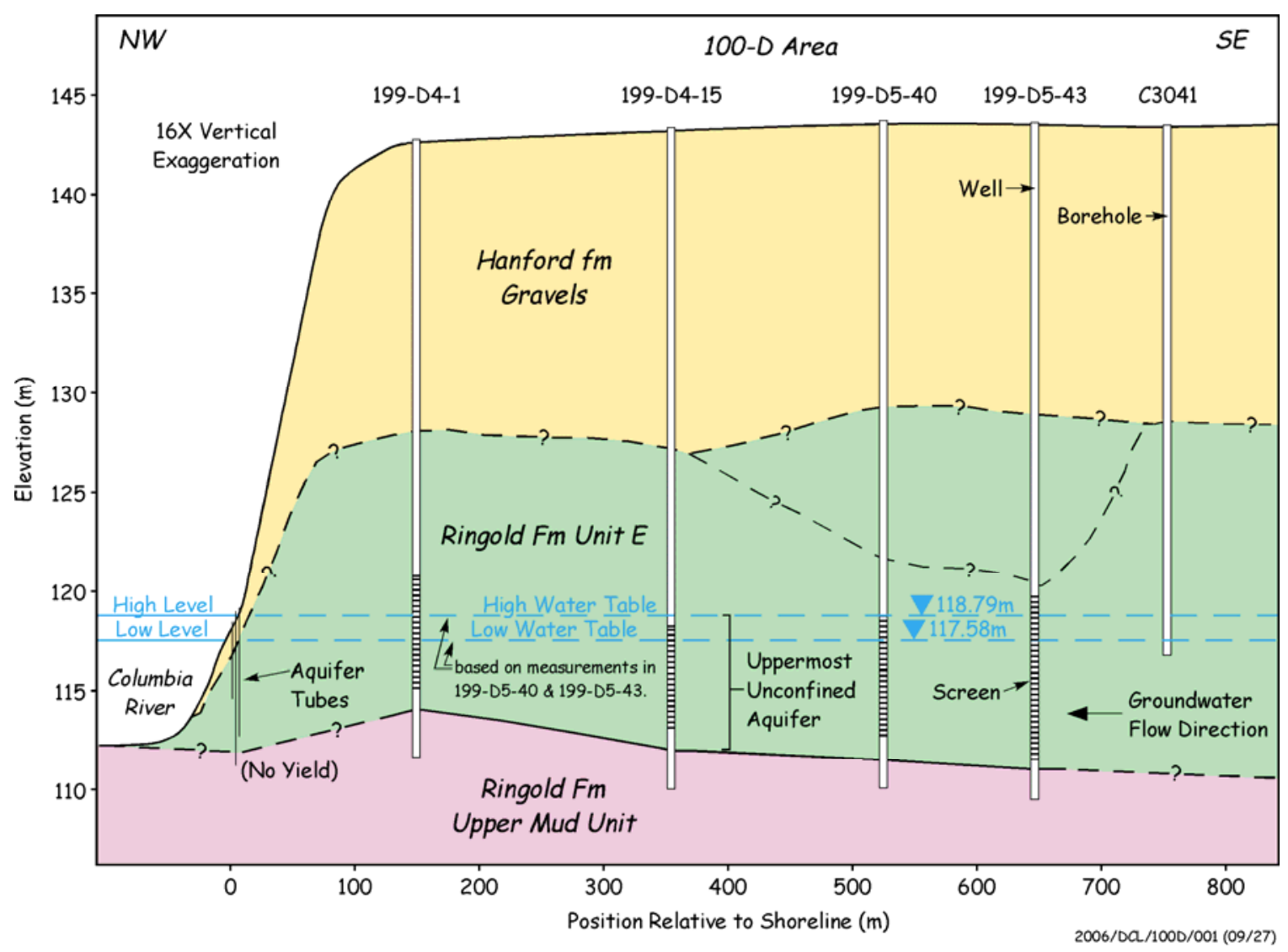

Figure 1.5. 100-D Area Hydrogeologic Cross Section of the Uppermost Aquifer 


\subsection{Treatment Technology Description}

In situ biostimulation has been extensively researched and applied for aquifer remediation over the last 20 years for various contaminants. In situ biostimulation, in the context of this project, is the process of amending an aquifer with a substrate that induces growth and/or activity of indigenous bacteria for the purpose of inducing a desired reaction. For application at the 100-D Area, the purpose of biostimulation is to induce reduction of chromate, nitrate, and oxygen to remove these compounds from the groundwater. Chromate can be biologically reduced to insoluble chromium (III) (e.g., Alam et al. 2006) and in situ chromate reduction has been recently demonstrated using polylactate as a substrate at the 100-H Area of Hanford (Hazen 2004 [available at http://esd.lbl.gov/ERT/hanford100h/results.html]). Nitrate can be biologically reduced using a variety of organic substrates including vegetable oil (e.g., Hunter 2001) and in situ nitrate reduction has been demonstrated at the Hanford Site (e.g., Hooker et al. 1998). Biological nitrate reduction occurs as a stepwise process where the initial intermediate degradation product is nitrite. Under some conditions, nitrite concentrations can accumulate during nitrate reduction and nitrite needs to be monitored as a potential unwanted product of nitrate reduction. The final, desired product of biological nitrate reduction is nitrogen gas. Dissolved oxygen is readily reduced by a wide variety of bacteria in the presence of a wide variety of organic substrates. These reductive processes are induced by introduction of an organic substrate and the resultant biological processes create geochemically reduced conditions in the aquifer (e.g., a low oxidation-reduction potential [ORP]). In addition to the organic substrate added to the aquifer, biomass that grows in response to the substrate is itself a substrate that can maintain reducing conditions and associated contaminant treatment after the initial substrate amendment has been depleted. As some of the biomass dies, it is used as an organic substrate by other bacteria and thereby maintains reduced conditions.

To meet the goals for the integrated strategy in the 100-D Area (outlined in Section 1.0), chromate, nitrate, and dissolved oxygen concentrations need to be reduced over a relatively large areal extent (up to 600 linear $\mathrm{m}$ of reactive barrier). Due to the potential for continuing chromate and nitrate sources, upgradient dissolved oxygen and relatively long $(700-\mathrm{m})$ chromate plume length, the biostimulation approach would also need to remain effective, or be readily rejuvenated over a long period of time (tens of years). The biostimulation implementation must also consider the site setting where the plume is present in the relatively low permeability but heterogeneous (i.e., potential for high permeability channels) Ringold Formation over a thickness of $\sim 5$ to $8 \mathrm{~m}$. Combination of a biostimulation barrier and an ISRM barrier is being tested to determine if it provides a lower cost way to maintain overall chromate plume treatment over the expected 40-year plume duration compared to the ISRM barrier alone.

There are two potential approaches for implementing a large-scale, long-duration biostimulation barrier. One approach is to periodically inject a soluble substrate that stimulates growth of bacteria in the subsurface, creates reducing conditions, and maintains reducing conditions while the biomass decays. Another approach is to inject an immiscible substrate that is retained in the aquifer around the injection well and slowly releases substrate to the groundwater for use by bacteria in maintaining reducing conditions. Performance and cost of a barrier using an immiscible substrate are highly dependent on the ability to effectively distribute the substrate around the injection well. Dissolved substrates, which have the potential to be distributed over larger volumes, may also be more susceptible than immiscible substrates to small scale high permeability channels that may impact the uniformity of the substrate distribution around the injection well. The soluble substrate and immiscible substrate approaches are discussed in more detail in the following sections. 


\subsection{Treatment Process: Soluble Substrate}

Soluble substrates can be readily distributed in the subsurface over a relatively large areal extent. These substrates are consumed by bacteria in a relatively short time period (weeks). However, biomass produced from consumption of the substrate can provide long term reducing conditions as the biomass decays (Sleep et al. 2005; Yang and McCarty 2000). Reduction of sediment iron by bacteria may also create additional long-term reducing capacity. There are multiple dissolved-phase substrates that can be used to biostimulate an aquifer. Molasses was selected for use in the dissolved substrate test cell. Molasses has a high solubility and low cost and is representative of the type of secondary waste substrates that may be available to minimize the long-term cost of the barrier (e.g., carbohydrate wastes). Molasses has also been used extensively for field-scale biostimulation and has shown favorable results to support anaerobic bioremediation (Borden and Rodriguez 2006), and chromate reduction (Gemoets et al. 2003).

The following reactions show initial fermentation (Equation 1) and oxidation (Equation 2) of sucrose (used as a surrogate for molasses) and resultant production of biomass $\left(\mathrm{C}_{5} \mathrm{H}_{7} \mathrm{O}_{2} \mathrm{~N}\right.$; McCarty 1975):

$$
\begin{aligned}
& \mathrm{C}_{12} \mathrm{H}_{22} \mathrm{O}_{11}+1.2 \mathrm{NH}_{3}=>1.2 \mathrm{C}_{5} \mathrm{H}_{7} \mathrm{O}_{2} \mathrm{~N}+2.6 \mathrm{H}_{2} \mathrm{O}+\mathrm{C}_{3} \mathrm{H}_{6} \mathrm{O}_{3}+\mathrm{C}_{2} \mathrm{H}_{6} \mathrm{O}+\mathrm{CO}_{2} \\
& \mathrm{C}_{12} \mathrm{H}_{22} \mathrm{O}_{11}+6 \mathrm{O}_{2}+1.2 \mathrm{NH}_{3}=>1.2 \mathrm{C}_{5} \mathrm{H}_{7} \mathrm{O}_{2} \mathrm{~N}+8.6 \mathrm{H}_{2} \mathrm{O}+6 \mathrm{CO}_{2}
\end{aligned}
$$

Because organic acids and ethanol are produced from initial fermentation of sucrose (molasses), subsequent fermentation of these products will produce additional biomass with an approximate total stoichiometric biomass yield of 2.5 moles biomass per mole of sucrose (molasses) during fermentation if biomass yield from acetate and hydrogen are not considered.

Initial design calculations were conducted using literature information for the necessary parameters. These calculations are at a scoping level and specific injection design parameters such as flow rate, concentrations, and durations will be completed after the initial site characterization phase of the project. The initial design considers implementation of a biostimulation barrier with a $15-\mathrm{m}$ radial extent from the injection well. The target biomass volume within the barrier was set to $20 \%$ of the pore volume based on the minimal changes in hydraulic conductivity observed with a similar volume of immiscible material (Hunter 2001; Coulibaly and Borden 2004). Using a biomass density of $1.03 \mathrm{~kg} / \mathrm{L}$ and a porosity of 0.14 (Williams et al. 2000), the target biomass concentration is $\sim 29 \mathrm{~kg}$-biomass $/ \mathrm{m}^{3}$-barrier. The stoichiometric yield of 2.5 mole biomass per mole sucrose ( $\sim 0.75 \mathrm{~g}$-biomass $/ \mathrm{g}$-sucrose) was reduced to an estimated yield of $0.5 \mathrm{~g}$-biomass $/ \mathrm{g}$-molasses to account for other constituents in the molasses. With a yield of $0.5 \mathrm{~g}$-biomass $/ \mathrm{g}$-molasses, $\sim 50 \mathrm{~g} / \mathrm{L}$ molasses will produce $29 \mathrm{~kg}$-biomass $/ \mathrm{m}^{3}$-barrier. The total pore volume of a barrier with a $15-\mathrm{m}$ radius and 7.6-m thickness is $\sim 760,000 \mathrm{~L}$. At a nominal flow rate of $190 \mathrm{~L} /$ minute ( $\sim 50 \mathrm{gpm})$, a $50 \mathrm{~g} / \mathrm{L}$ solution of molasses would be distributed within the barrier over an injection period of $\sim 3$ days (though lower concentrations and multiple injection periods may be selected during the final design process.). At a radius of $15 \mathrm{~m}$, the radial velocity of the injected water will be $\sim 2.7 \mathrm{~m} /$ day, still significantly higher than the nominal regional groundwater velocity of $0.3 \mathrm{~m} /$ day. Once injected, the molasses would be consumed to produce biomass over a period of weeks. The longevity of the barrier would then be related to the endogenous decay rate of the biomass. Sleep et al. (2005) and Yang and McCarty (2000) reported a first-order endogenous decay coefficient on the order of 0.005/day under similar conditions. At this decay rate, it would take $\sim 1$ year to deplete the biomass within the barrier. These rough calculations show that the molasses barrier is feasible in terms of the amount of substrate required and the estimated duration of the reducing conditions. 
Reactive transport simulations will be conducted after parameter values from the laboratory experiments are obtained and using the site characterization data obtained in the first phase of the project. The simulations will be used to estimate the concentration of nitrate, chromate, and oxygen over time at the injection well and monitoring well locations. The results will also provide an estimate for how upgradient nitrate, chromate, and oxygen concentrations will be reduced while the barrier is active. These simulation concentration profiles will provide a basis for evaluation of the field monitoring data that will be collected during the treatability test.

The initial design analysis was conducted using parameters from related studies reported in the scientific literature. The design will be refined using site-specific parameters for microbial process that will be obtained in laboratory tests conducted using sediments retrieved from the 100-D subsurface during installation of the wells for the treatability test. The laboratory tests are summarized in Section 2.3 and a detailed laboratory test plan for these experiments is included as Appendix A.

\subsection{Treatment Process: Immiscible Substrate}

Immiscible substrates can provide substrate to maintain reducing conditions over a long period of time (years) because the substrate consumption is controlled by the rate of dissolution (Parsons 2004). The immiscible substrate can be injected into an aquifer as a separate phase or as an emulsion. However, injection of a separate phase can cause significant hydraulic conductivity reduction and cannot distribute substrate very far from the injection well (Coulibaly and Borden 2004). Use of stable emulsions offer the potential for distribution over a larger areal extent (on the order of $5 \mathrm{~m}$ ) and the distributed oil at a weight percentage on the order of $1 \%$ has minimal reduction in hydraulic conductivity (Hunter 2001, 2005; Coulibaly and Borden 2004). Because of the large areal extent necessary for full-scale application in the 100-D Area, the treatability test will focus on immiscible substrates that can be delivered as an emulsion. Soybean oil can be effectively emulsified (Coulibaly and Borden 2004). A recent study of slow-release substrates for anaerobic bioremediation showed favorable results for soybean oil or hydrogenated soybean oil (Borden and Rodriguez 2006). Hunter $(2001,2005)$ has shown effective denitrification using soybean oil and that the tested emulsifier does not significantly inhibit denitrification (Hunter 2005).

Soybean oil releases long-chain fatty acids and glycerol to the groundwater and these compounds are subsequently degraded producing other daughter products that can be further degraded (Borden and Rodriguez 2006). The overall reactions in the groundwater are controlled by rate of dissolution, hydrolysis, and associated solubility for the oil. Potentially, hydrogenated soybean oil may provide longer-lasting substrate because it is less soluble and may be more slowly hydrolyzed than soybean oil (Borden and Rodriguez 2006). Because mass transfer processes control the reactions and longevity of the reducing conditions, biomass yield and decay are not as important as they are for the soluble substrates. Thus, design calculations are based primarily on the rate of reactions as controlled by the oil dissolution and the distribution of the oil within the subsurface.

Initial design calculations were conducted using literature information for the necessary parameters. These calculations were conducted at a scoping-level and specific injection design parameters such as flow rate, concentrations, and durations will be completed after the initial site characterization phase of the project. The initial design considers implementation of an oil-based reducing barrier with a 5-m radius from the injection well. Within the barrier radius, oil would be distributed to obtain approximately $1 \mathrm{wt} \%$ (computed as kg-oil $/ \mathrm{kg}$-soil) of oil. At $1 \mathrm{wt} \%$ oil and an oil density of $0.92 \mathrm{~kg} / \mathrm{L}$, the oil volume is approximately $14 \%$ of the pore volume which has been shown to have insignificant impact on hydraulic 
conductivity (Hunter 2001; Coulibaly and Borden 2004). The longevity of the barrier is related to the oil consumption rate. Hunter (2001) measured the rate of denitrification, oxygen reduction and the corresponding consumption of oil in a bench-scale experiment where the initial oil in the barrier was $1 \mathrm{wt} \%$. These data correspond to an overall zero-order oil consumption rate of $0.026 \mathrm{~kg} / \mathrm{d}-\mathrm{m}^{3}$ under conditions where nitrate $(88 \mathrm{mg} / \mathrm{L})$ and oxygen $(8 \mathrm{mg} / \mathrm{L})$ were constantly added in the influent of the bench-scale flow cell with a groundwater velocity of $3.6 \mathrm{~m} /$ day. Data in Hunter (2001) can also be used to calculate that 263 pore volumes of water were treated to remove the nitrate and oxygen before breakthrough of nitrate began to occur (10 weeks). While groundwater flow conditions at the 100-D Area are different than the conditions applied by Hunter (2001), the longevity of the barrier can be estimated from this information. Assuming that the overall oil consumption rate applies everywhere in the barrier (e.g., it is not a function of groundwater flow rate or electron acceptor concentration) and that oil consumption can be estimated as a zero order rate over the duration of the barrier life, the duration of an oil-based barrier in the 100-D Area would be $\sim 2$ years. Using the number of pore volumes treated by Hunter (2001) and an assumed effective barrier thickness of $5 \mathrm{~m}$ (considers a 0.6-m overlap between injected oil zones so that the barrier thickness is not the full diameter), the duration of an oil-based barrier in the 100-D Area would be $\sim 11$ years. Extremely high denitrification and oxygen reduction rates were supported in the bench scale tests by Hunter (2001). At the observed rates, nitrate and oxygen would be rapidly depleted within the barrier and breakthrough at monitoring wells would occur only after the oil was substantially depleted in the area of the barrier upgradient of the monitoring location. It is expected that chromate reduction rates would also be high with a similar breakthrough pattern.

The initial design analysis was conducted using parameters from related studies reported in the scientific literature. The design will be refined using site-specific parameters for microbial process that will be obtained in laboratory tests conducted using sediments retrieved from the 100-D Area subsurface during installation of the wells for the treatability test. The laboratory tests are summarized in Section 2.3 and a detailed laboratory test plan for these experiments is included as Appendix A. Additionally, obtaining a large radial injection distance is a primary factor in the cost effectiveness for biostimulation using an immiscible substrate at the large scale that would be required for implementation in the 100-D Area. Therefore, bench-scale testing and obtaining external consultation for preparation of stable emulsions is part of the design process as described in Section 2.4 with additional information shown in Appendix B.

\subsection{Laboratory Study}

Laboratory tests are being conducted to support design of the field test. A detailed laboratory test plan is included in Appendix A. In summary, the following questions will be addressed for use of molasses and subsequent endogenous microbial decay as a long-term substrate for the reducing barrier:

1. What is the appropriate concentration of molasses to use in the field test?

2. What is the yield of biomass from molasses alone or from molasses and nitrate or from molasses and chromate or from molasses, nitrate, and chromate?

3. What is the rate of molasses consumption, denitrification, and chromate reduction when molasses is present?

4. What is the rate of denitrification and chromate reduction during endogenous microbial decay?

5. What is the rate of endogenous microbial decay? 
6. Is the rate of endogenous microbial decay and coincident denitrification, or chromate reduction dependent on whether nitrate or chromate are present during biomass growth?

7. What is the rate of molasses consumption under aerobic conditions?

The following questions will be addressed for use of vegetable oil as a long-term substrate for the reducing barrier:

1. What is the rate of denitrification and chromate reduction stimulated by vegetable oil?

2. What is the rate of oil loss during active denitrification, chromate reduction, oxygen reduction, and fermentation processes?

3. What is the aqueous-phase concentration of dissolved oil or fermentation products during oxygen reduction and fermentation processes?

4. What is the aqueous-phase concentration of dissolved oil without oxygen reduction or fermentation processes?

\subsection{Bench-Scale Study}

Bench-scale tests are also being conducted to support design of the field test. A key objective of the biostimulation treatability test is to demonstrate that a biostimulation zone can be installed over a relatively large radial distance from an injection well in the Ringold Formation. Obtaining a large radial injection distance is a primary factor in the cost effectiveness for biostimulation at the large scale that would be required for implementation in the 100-D Area. Vegetable oil is anticipated to be a suitable long-duration substrate as has been demonstrated at other sites. However, injections at other sites have been at a smaller scale than what is needed at the Hanford Site. Recent research in the last few years has identified use of micron-scale vegetable oil emulsions as a potentially viable method to enhance the radial injection distance. Bench-scale tests will be used to evaluate the site-specific emulsion preparation and injection parameters for the Hanford Site test. A summary of the bench-scale test plan is included in Appendix B.

Efforts will focus on identifying the emulsion properties that provide the best chances of large radial injection distance in the Ringold Formation and testing emulsion transport in bench-scale flow cells to identify injection parameters and evaluate the impact of the Ringold Formation particle-size distribution. Sediment particle size distribution has a significant effect on emulsion transport because filtration processes are an important factor controlling transport distance and variation in particle sizes (e.g., presence of silt, sand, gravel, and cobbles within the porous media matrix) impacts injection flow patterns. Bench tests will be conducted in the Environmental Molecular Science Laboratory's Subsurface Flow and Transport Laboratory using techniques and flow cells similar to those used in the recent testing of iron particle carrier fluids.

The bench tests and input from industry/university consultants will provide information to guide the design for vegetable oil injection, enhance the probability of obtaining a large radial injection distance, and reduce the technical uncertainty for vegetable oil injection in the field. 


\subsection{Performance and Data Quality Objectives}

This section identifies the treatability test performance objectives and the associated data quality objectives necessary to meet the performance objectives.

\subsection{Test Performance Objectives}

The overall objectives of the treatability test are as follows:

- Demonstrate field-scale reduction of chromate, nitrate, and dissolved oxygen concentrations and the longevity of treatment to evaluate the effectiveness of the process at full scale.

- Demonstrate field-scale application of biostimulation to evaluate implementability of the process at full scale.

- Determine the number of wells, type of substrate, operational strategy, and longevity for biostimulation such that costs for full-scale application can be effectively estimated.

\subsection{Data Quality Objectives}

This section summarizes the decisions that will be addressed by the biostimulation treatability test. Table 3.1 shows the key decisions for implementing a biostimulation barrier and the type of data that will be collected to address these items. These data items are incorporated into the field test operation herein and associated Sampling and Analysis Plan (Section 6.0) that guide how the test will be conducted.

\subsection{Comparison Levels}

The biostimulation barrier is planned for deployment upgradient of the existing ISRM barrier. Thus, treatment goals are primarily associated with reducing the flux of electron acceptors into the ISRM barrier and not necessarily drinking water goals. For the purpose of the treatability test, goals for the primary electron acceptors nitrate/nitrite, chromate, and oxygen will be $1 \mathrm{mg} / \mathrm{L}, 22 \mu \mathrm{g} / \mathrm{L}$, and $0.5 \mathrm{mg} / \mathrm{L}$, respectively. A chromate concentration of $11 \mathrm{ppb}$ is the target goal in the river. To account for dilution within the aquifer between the monitoring location on-shore and the aquatic receptor exposure point of concern within the river substrate, a dilution factor of 1:1 is assumed so that $22 \mathrm{ppb}$ would be the goal at the compliance point within the aquifer (EPA 1996). The goals for the other two constituents were selected to represent acceptably low electron acceptor concentrations. Measurements for nitrate, nitrite (a potential byproduct of denitrification), chromate, and dissolved oxygen within the barrier will be major inputs for evaluating the performance of the barrier. 
Table 3.1. Biostimulation Barrier Key Decisions

\begin{tabular}{|c|c|c|c|}
\hline $\begin{array}{l}\text { Primary } \\
\text { Objective }\end{array}$ & Decision & $\begin{array}{c}\text { Detailed } \\
\text { Sub-objectives }\end{array}$ & Data for Analysis \\
\hline \multirow[t]{4}{*}{ Design Barrier } & \multirow[t]{3}{*}{$\begin{array}{l}\text { Barrier } \\
\text { Dimensions }\end{array}$} & $\begin{array}{l}\text { Radial influence of } \\
\text { substrates }\end{array}$ & $\begin{array}{l}\text { Tracer, conductance, and TOC breakthrough at monitoring wells } \\
\text { assessed at } 4 \text { different radial distances; laboratory test data for substrate } \\
\text { utilization rate during injection (soluble substrate only) to estimate } \\
\text { impact on biomass distribution via numerical modeling. }\end{array}$ \\
\hline & & $\begin{array}{l}\text { Rate of nitrate, } \\
\text { chromate, and } \\
\text { oxygen reduction }\end{array}$ & $\begin{array}{l}\text { Nitrate, chromate and oxygen breakthrough at monitoring wells, and } \\
\text { nitrate reduction and disappearance at six different monitoring locations } \\
\text { at different distances from upgradient edge of treatment zone; hydraulic } \\
\text { gradient, aquifer hydraulic conductivity and tracer dilution at } \\
\text { monitoring wells to determine groundwater flow direction and velocity; } \\
\text { laboratory test data for nitrate, chromate and oxygen reduction to } \\
\text { determine rate of reduction under laboratory conditions. }\end{array}$ \\
\hline & & $\begin{array}{l}\text { Required overlap } \\
\text { of injections to } \\
\text { form a barrier }\end{array}$ & $\begin{array}{l}\text { Tracer, conductance, and TOC breakthrough at monitoring wells } \\
\text { assessed at four different radial distances; analyzed with numerical } \\
\text { model to estimate total radial extent of treatment and evaluate well } \\
\text { spacing requirements. }\end{array}$ \\
\hline & $\begin{array}{l}\text { Reinjection } \\
\text { Interval }\end{array}$ & $\begin{array}{l}\text { Duration of } \\
\text { reducing } \\
\text { conditions }\end{array}$ & $\begin{array}{l}\text { Nitrate, chromate and oxygen breakthrough at monitoring wells, and } \\
\text { nitrate reduction and disappearance at } 6 \text { different monitoring locations } \\
\text { at different travel distances from upgradient edge of treatment zone } \\
\text { hydraulic gradient, aquifer hydraulic conductivity and tracer dilution at } \\
\text { monitoring wells to determine groundwater flow direction and velocity; } \\
\text { laboratory test data for nitrate, chromate and oxygen reduction to } \\
\text { determine rate of reduction under laboratory conditions. }\end{array}$ \\
\hline \multirow[t]{6}{*}{$\begin{array}{l}\text { Evaluate } \\
\text { Barrier } \\
\text { Performance }\end{array}$} & \multirow[t]{2}{*}{$\begin{array}{l}\text { Injection } \\
\text { Performance }\end{array}$} & $\begin{array}{l}\text { Spatial distribution } \\
\text { of substrates }\end{array}$ & $\begin{array}{l}\text { Tracer, turbidity, conductance, and TOC breakthrough at } 4 \text { monitoring } \\
\text { wells in different radial locations (and two vertical positions at one of } \\
\text { the radial monitoring locations) assessed for uniformity and for "drift" } \\
\text { of substrate after initial injection }\end{array}$ \\
\hline & & $\begin{array}{l}\text { Injection pressure } \\
\text { and flow rate }\end{array}$ & Process data monitored during injection \\
\hline & \multirow[t]{2}{*}{$\begin{array}{l}\text { Barrier } \\
\text { Performance }\end{array}$} & $\begin{array}{l}\text { Longevity of } \\
\text { reducing } \\
\text { conditions }\end{array}$ & $\begin{array}{l}\text { Nitrate, chromate and oxygen breakthrough at monitoring wells, and } \\
\text { nitrate reduction and disappearance at six different monitoring locations } \\
\text { at different travel distances from upgradient edge of treatment zone } \\
\text { hydraulic gradient, aquifer hydraulic conductivity and tracer dilution at } \\
\text { monitoring wells to determine groundwater flow direction and velocity; } \\
\text { laboratory test data for nitrate, chromate and oxygen reduction to } \\
\text { determine rate of reduction under laboratory conditions. }\end{array}$ \\
\hline & & $\begin{array}{l}\text { Rate/extent of } \\
\text { nitrate, chromate, } \\
\text { and oxygen } \\
\text { reduction observed } \\
\text { in barrier }\end{array}$ & $\begin{array}{l}\text { Nitrate, chromate, and oxygen concentrations monitored over time at } \\
\text { six locations within the treatment zone; laboratory test data for nitrate, } \\
\text { chromate and oxygen reduction to determine rate of reduction under } \\
\text { laboratory conditions. }\end{array}$ \\
\hline & \multirow[t]{2}{*}{ Side Effects } & $\begin{array}{l}\text { Aquifer plugging } \\
\text { in barrier }\end{array}$ & Hydraulic property test before and after barrier installation. \\
\hline & & $\begin{array}{l}\text { Impact on water } \\
\text { quality }\end{array}$ & Water quality parameter monitoring before and after barrier installation. \\
\hline $\begin{array}{l}\text { Economic } \\
\text { Feasibility }\end{array}$ & $\begin{array}{l}\text { Economic } \\
\text { Evaluation }\end{array}$ & $\begin{array}{l}\text { Design, } \\
\text { installation, } \\
\text { operation/re- } \\
\text { injection costs }\end{array}$ & $\begin{array}{l}\text { Reagent quantities, equipment and material requirements, and labor } \\
\text { requirements for installation and maintenance of the barrier. }\end{array}$ \\
\hline
\end{tabular}




\subsection{Compliance with Applicable or Relevant and Appropriate Requirements}

In accordance with EPA's Guide to Conducting Treatability Studies Under CERCLA (EPA 1992), onsite treatability tests may be conducted without any federal, state, or local permits (40 CFR $300.400[\mathrm{e}][1])$; however, such studies must meet applicable or relevant and appropriate requirements (ARARs) under federal or state environmental laws or be exempted by a waiver under the Comprehensive Environmental Response, Compensation, and Liability Act (CERCLA) Section 121(d)(4).

The ISRM treatability test will be conducted in the groundwater 100-HR-3 Operable Unit with the Washington State Department of Ecology (Ecology) as the lead regulatory agency of this operable unit as described in the Hanford Federal Facility Agreement and Consent Order (Ecology et al. 1989). Should unforeseen conditions warrant, Ecology (as the responsible regulatory agency in consultation with DOE Richland Operations Office [RL]) has the authority to terminate the treatability test.

The ISRM treatability test will occur approximately $400 \mathrm{~m}$ inland from the Columbia River in an area that is not expected to be culturally or ecologically sensitive. The test requires the construction of groundwater wells. The test also has the potential to generate waste and wastewater. The major ARARs pertinent to this treatability test include the following:

- groundwater standards

- Columbia River protection standards

- cultural and ecological resource-protection requirements

- waste and wastewater management standards.

\subsection{Groundwater Standards}

The biostimulation treatability test will inject molasses, soybean oil, food-grade emulsifier, potassium bromide, and ammonium chloride. Contaminated groundwater currently discharges to the Columbia River from the contaminated aquifer. Chromate and other water quality measurements in the test cells will be used to evaluate the effectiveness and potential side effects of the biostimulation process. This evaluation will be made by comparing these measured concentrations to water quality standards for groundwater (WAC 173-200, "Water Quality Standards for Ground Waters of the State of Washington") and to 40 CFR 131.36.

Significant changes to the groundwater chemistry other than lowering the ORP and temporary increases in biomass concentrations are not expected. The project work scope will meet the requirements of WAC 173-218, "Underground Injection Control Program," including injection well registration; and related requirements in 40 CFR 144, Subpart B; WAC 173-160, "Minimum Standards for Construction and Maintenance of Wells"; and WAC 173-162, "Regulation And Licensing Of Well Contractors And Operators."

The biostimulation process will have an impact on the dissolved oxygen concentrations of the aquifer within and downgradient of the reduced zone. The attenuation of the downgradient anoxic plume is expected to occur from several processes, including the following: diffusion, dispersion, entrapment of air 
from water table fluctuations, and from trapped air bubbles within the saturated aquifer zone. Because of the relatively small scale of the tests, no significant effects are anticipated on the downgradient dissolved oxygen concentrations in the 100-D Area.

Certain trace metals (iron, manganese, zinc) may be elevated above the baseline concentrations of the aquifer within the reduced zone due to the altered oxidation-reduction (Eh) conditions created by the biostimulation process. These trace metals are not expected to be elevated above baseline values downgradient of the reduced zone due to the low mobility of these metals, and the reoxidation/precipitation of the metals when they contact the oxidized sediments downgradient from the reduced zone. Monitoring of trace metals within the test cells is planned as part of this study to evaluate potential biostimulation side effects.

\subsection{Columbia River Protection Standards}

Technology-based limitations and standards, controlling toxic pollutants, and monitoring for discharges to U.S. waters (including stormwater) are addressed in 40 CFR 122. The Hanford Reach Study Act (Public Law 100-605, as amended) regulations are applicable to planning, designing, and locating activities in a manner that minimize direct and adverse effects on the values for which the Columbia River is under study. The treatability test will be conducted outside the 0.4-km boundary of the Columbia River and therefore is not subject to these regulations. The Clean Water Act of 1977 (33 USC 1251 et seq.), 40 CFR 131, and WAC 173-201A-040, "Water Quality Standards for Surface Waters of the State of Washington" will be considered with respect to potential impacts to the Columbia River.

\subsection{Cultural and Ecological Resource Protection Standards}

Cultural resource protection requirements apply because of the potential presence of significant archeological sites or artifacts in the 100-D Area. An initial cultural resource survey was performed as part of previous similar activities in the area (e.g., the ISRM barrier) and a site-specific survey will be conducted at the biostimulation field test site as part of the drilling authorization requirements. The National Historic Preservation Act (16 USC 470 et seq.) is applicable and requires federal agencies to take into account the effect of an activity on any significant cultural resource. This act requires action to recover and preserve artifacts in areas where activity may cause irreparable harm, loss, or destruction of significant artifacts.

The Endangered Species Act (7 USC 136) prohibits activities that threaten the continued existence of listed species or destroy critical habitat. The Migratory Bird Treaty Act (16 USC 703) is applicable to protection of migratory birds in the areas. Washington State implements the Bald and Golden Eagle Protection Act under WAC 232-12-292, "Bald Eagle Protection Rules." These rules are applicable due to the known roosting of bald eagles along the Columbia River. Although threatened and endangered species are known to be present in the 100 Areas, a biological survey was conducted as part of previous similar activities in the area (e.g., the ISRM barrier) and identified no potential impacts on protected species or critical habitat. A site-specific survey will be conducted at the biostimulation field test site as part of the drilling authorization requirements. 


\subsection{Waste and Wastewater Management Standards}

All treatability test residuals will be evaluated and managed in compliance with appropriate waste regulations. WAC 173-303, "Dangerous Waste Regulations," requires the identification and appropriate management of dangerous wastes. WAC 173-304, "Minimum Functional Standards for Solid Waste Handling," requires the identification and appropriate management of solid wastes that are not dangerous wastes. Solid wastes generated during the test (i.e., drill cuttings) will be disposed of, as required, at the Environmental Restoration Disposal Facility (ERDF), which is designed to meet the substantive standards for disposal of solid and dangerous wastes. Purgewater generated during development, aquifer testing, and sampling of these wells will be managed per Hanford Site requirements. Pacific Northwest National Laboratory (PNNL) will work with Fluor Hanford, Inc. to arrange for the transport and appropriate disposal of all investigation-derived waste. 


\subsection{Conceptual Design}

This section outlines the conceptual design of the test. This design, related information, and testing procedures will be refined based on the characterization information collected during and just after installation of the test site wells and using the results of the laboratory testing with test site sediments (see Appendices A and B).

\subsection{Treatability Test Approach}

The approach for the field test is to install two test cells, each consisting of an injection well surrounded by monitoring wells (Figure 5.1). The test cells will be located such that an existing well can be used as an upgradient, unimpacted monitoring location for both test cells. During well installation, sediment samples will be collected and used in laboratory microcosm studies to confirm that the substrates induce chromate, nitrate, and dissolved oxygen reduction and bench-scale studies for emulsion transport (see Appendices A and B). Field test operations will be conducted by injecting the substrate using a raw water supply as the carrier solution. Dissolved oxygen will be present in the carrier water and may be removed by addition of a small dose of reducing agent depending on the results of the laboratory tests. The injected water/substrate will displace chromate- and nitrate-contaminated groundwater during the injection. However, this displacement will be used to assist in evaluating the longevity of the treatment. Because chromate and nitrate will be initially absent in the treatment area, the injection and monitoring locations can be used to evaluate the breakthrough of chromate and nitrate at these locations as a means to assess when the reductive capacity has been exhausted. This monitoring process is shown conceptually on Figures 5.1. These data address the effectiveness and implementability objectives for the test. Distribution of the vegetable oil substrate will be assessed using geophysical methods and through monitoring of groundwater total organic carbon, turbidity, and a conservative tracer at the monitoring locations during and just after injection. Molasses distribution will be assessed through monitoring of groundwater total organic carbon and a conservative tracer at the monitoring locations during and just after the injection. These data and the operational aspects of the test will address the implementability objective for the test. The design and operational aspects of conducting the test in conjunction with the performance and distribution data will provide a basis to determine system scale-up and estimate cost for full-scale application; thereby addressing the cost objective of the test.

Through testing of the two different types of potential substrates (immiscible and soluble), the testing will enable evaluation of how each substrate performs under field conditions (e.g., in the presence of field-scale heterogeneities) and will provide valuable information to assess the substrate best suited for application at the large scale necessary to meet the overall goals of the integrated strategy for the 100-D Area chromate plume. 


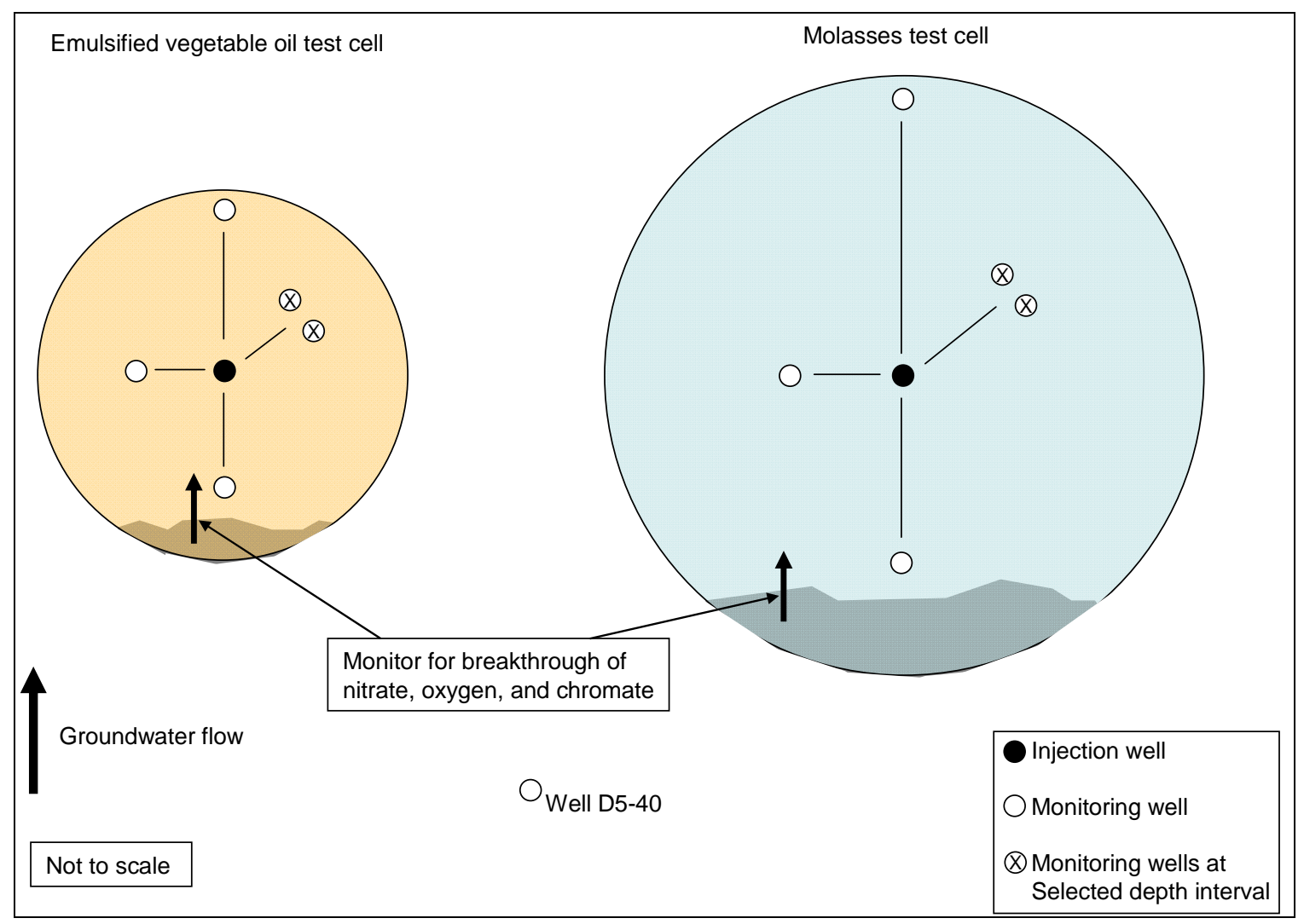

Figure 5.1. Conceptual Layout of Test Cells (to be Finalized During the Design Process)

\subsection{Treatability Test Activities}

The overall project work scope is to demonstrate a biostimulation process for reduction of chromate, nitrate, and dissolved oxygen concentrations in groundwater upgradient of the ISRM barrier. Field-scale treatability testing of biostimulation in the 100-D Area is divided into five tasks as follows:

1. Project Management

2. Biostimulation Design Analysis

3. Pilot-Scale Injection Test

4. Performance Assessment Monitoring

5. Data Analysis and Reporting.

Each task is described in the following sections. Project-controlled field test instructions will be prepared prior to field work to describe details of specific field activities noted below.

\section{Task 1: Project Management}

Subtask 1a - Project Support. Scientists will plan, organize, and provide top-level guidance and direction for overall project performance. This task also includes management of subcontracts and work orders associated with conducting field work (e.g., drilling support). Project-level cost and schedule 
control, tracking, reporting, and coordination with the Columbia River Protection Supplemental Technologies Project work scope through RL, the Groundwater Remediation and Closure Assessment Project, and the DOE Office of River Protection are part of this task.

Subtask $1 b$ - Planning and Test Plan Preparation. Scientists will develop both a laboratory-scale experimental approach and a field-scale treatability testing approach, and prepare planning documents. The field-scale treatability test plan is the primary project document that describes the laboratory test plan, site-specific characterization, and field test plan. The initial treatability test plan will be based on the initial design analysis. The field-scale treatability test plan will be revised as needed based on laboratory testing results and site-specific characterization efforts.

\section{Task 2: Biostimulation Design Analysis}

Work for the two subtasks is as follows: 1) define the hydrogeological and biogeochemical conceptual model of the Ringold Formation in the zone targeted for the treatability test; and 2) develop an initial design of the treatability test system.

\section{Subtask 2.1 - Site Conceptual Model of Hydrogeological and Biogeochemical Conditions.} Scientists will evaluate the hydrogeological and biogeochemical conditions from existing wells and boreholes in the vicinity of the proposed treatability test site, and incorporate this evaluation into a working conceptual site model.

Subtask 2.2 - Initial Design of the Treatability Test System. Scientists will develop a test design that describes the well network, injection equipment, injection approach, and monitoring procedures for the test based on data available prior to well installation at the site. The test design will include a description of the scale-up issues, how these issues are addressed in the test design, and tools used to complete the design. The test design will be finalized in Task 3 to incorporate laboratory test results and characterization information collected during installation of the test site well network.

\section{Task 3: Pilot-Scale Injection Test}

Scientists will install the test site well network and associated site-specific characterization, conduct laboratory tests to support system design, finalize the test design, perform substrate injection, and evaluate the substrate distribution.

Subtask 3.1 - Well Installation and Site-Specific Characterization. Based on the initial test design completed in Task 2, scientists will install injection and monitoring wells at each of the two test cell locations. Data will be collected during well drilling and used to refine the hydrogeologic and geochemical conceptual model and finalize the substrate injection design.

Following well network installation, several hydrogeologic characterization methods will be used to obtain additional site-specific information. These tests include hydraulic testing to obtain formation hydraulic properties (e.g., slug interference and recovery tests) and electromagnetic borehole flowmeter (EBF) testing to assess the vertical distribution of horizontal hydraulic conductivity (i.e., vertical heterogeneities).

Subtask 3.2 - Laboratory-and Bench-Scale Studies. Sediment samples collected during well installation will be tested for response to biostimulation. The basis for this testing is to assure that 
Ringold Formation gravels are similar in biostimulation response to the Hanford formation near the 100-H Area where the previous test of polylactate was conducted, and to define the necessary site-specific microbial parameters needed for the design calculations. A detailed laboratory test plan is included in Appendix A. Additionally, bench-scale tests will be conducted to define an appropriate site-specific stable emulsion preparation, and determine the emulsion-injection parameters as described in Appendix B.

Subtask 3.3 - Final Design Analysis. Information from the laboratory tests and field characterization effort will be used to finalize the injection strategy and test operational approaches for each substrate. The field test plan will be finalized as part of this subtask.

Subtask 3.4 - Substrate Injection. Substrate injections for each test cell will be conducted following the procedures in the field test plan (described in Subtask 3.3). Chemical monitoring will be conducted during injection to evaluate substrate distribution. A conservative tracer (potassium bromide) will be co-injected with the substrate and monitored to assess substrate distribution and degradation during the injection process. Process monitoring over an 8 -week period after injection will be conducted to assess the initial reactions within the barrier that create reducing conditions, and to assess substrate drift under natural gradient conditions.

Subtask 3.5 - Geophysical Assessment of Emulsified Vegetable Oil Distribution. Geophysical characterization will be applied to evaluate the radial distribution of the emulsified vegetable oil around the injection well. A detailed characterization approach is provided in Appendix C.

\section{Task 4: Performance Assessment Monitoring}

Groundwater samples will be collected and analyzed to evaluate treatment performance. Hydraulic tests will be conducted following emplacement of the treatment zone and compared with pretreatment values to assess the impact of treatment on aquifer hydraulic properties.

Subtask 4.1 - Groundwater Analyses. Primary performance monitoring will be via periodic spectrophotometric (Hach kit) and ion chromatography (IC) analyses to assess the temporal pattern of chromate and nitrate/nitrite concentrations, respectively, at each of the test-cell wells. These data will be used along with coincident dissolved oxygen, ORP, and specific conductance measurements as the primary indicators for the longevity of the reductive zone induced by biostimulation. Concentration of conservative tracers within the test cell will also be monitored to assist in evaluating the residence time of groundwater in the reduced zone under natural gradient conditions. Inductively coupled plasma-mass spectrometry (ICP-MS) and ICP-optical emission spectrometry (ICP-OES) will be used to augment IC data to quantify aqueous cation, anion and trace-metal concentrations before treatment and at two time points while the test cell is maintaining reduced conditions to evaluate the impact of biostimulation on groundwater geochemistry.

Subtask 4.2 - Post-treatment Hydraulic Testing. Hydraulic testing using slug interference techniques to minimize impact to the test cell will be conducted following emplacement of the treatment zone and compared with pretreatments measurements to assess the impact of biostimulation and substrate injection on aquifer hydraulic properties. Specifically, pre- and post-treatment hydraulic responses will be compared to assess aquifer plugging. 


\section{Task 5: Data Analysis and Reporting}

Scientists will manage, compile, and evaluate all data generated during the treatability studies and prepare a treatability test report. The final report will cover activities ranging from basic laboratory development work through a field-scale demonstration of the technology. Findings in this report will form the basis of an evaluation of this technology for full-scale implementation.

\subsection{Well Installation}

Injection and monitoring wells will be installed at the 100-D Area test site, approximately $30 \mathrm{~m}$ downgradient of existing well 199-D5-40 (Figure 1.1). The monitoring wells will be installed for operational monitoring (i.e., to monitor injection of the treatment solution) and will be installed within a radial distance of $\sim 15 \mathrm{~m}$ for the molasses injection well and $\sim 5 \mathrm{~m}$ for the emulsified vegetable oil injection well (Figure 5.1 through Figure 5.3). Drilling, sampling, and well-completion specifications are described in detail in Appendix D.

The two central injection wells will be screened across the entire $\sim 7.6 \mathrm{~m}$ of the aquifer. Based on the current conceptual understanding of the test site locations and available budget for well installation, it is anticipated that the monitoring wells will also be screened to monitor the full $\sim 7.6 \mathrm{~m}$ of saturated aquifer thickness. One set of upper/lower aquifer monitoring well pairs for each well network is planned. The proposed well layout is shown in Figure 5.1.

Continuous coring will be conducted in the two central injection boreholes to provide data to assess the microbiological community in the saturated sediment. To maintain the integrity of the sediment core samples that are being collected for geochemical and/or microbial analysis, samples will be collected using an aseptic collection protocol. A detailed lithologic description of drill cuttings and returned sediment will be provided by the well site geologist from ground surface to total depth. This description will include the following: 1) drilling conditions and changes in drilling conditions (e.g., drilling method, drill rate, addition of fluids, heaving sand), 2) depths and types of all collected samples, 3) lithologic descriptions of sediments, including relative moisture, 4) results of radiation and chemical monitoring of sediments, and 5) water level.

If the collection of sediment grab samples does not significantly impact overall well installation cost, depth discrete core samples may also be collected during installation of the monitoring wells as required to support bench-scale testing. Sediment grab samples would be collected over depth intervals of interest and at changes in lithology or at depths where unusual conditions are encountered (as determined by the field geologist). Samples would be collected in pint or quart glass jars capable of sealing existing moisture in the sample for a reasonable time period. If representative samples cannot be collected (for example, if large particles do not fit in the container), notes describing the condition of the sample will be put in the geologist's log. All sediment samples that are collected will be labeled (well number and depth), and (if appropriate) radiation released. Chip tray samples will be collected at regular intervals, with additional samples as required to adequately characterize changes in lithology over the full depth interval of the borehole.

As with sediment core sampling, geophysical logging will only be conducted in the two injection boreholes if it does not significantly impact overall well installation cost. Subsurface spectral gamma geophysical logging may be conducted based on contractor availability and the potential for impact to the 
drilling schedule. Geophysical logging would be conducted by others over the total drill depth for identification of contaminants, site characterization, stratigraphic correlation, and for determination of well screen length and placement. Anomalous or unusual readings may be re-logged as necessary.

Injection wells will be completed using either 15.2- or 10.2-cm-diameter schedule 40 PVC casings and PVC continuous wire wrap screens. Monitoring wells will be completed using 10.2-cm-diameter schedule 40 PVC casings and PVC continuous wire wrap screens. All well screens will be 20 -slot and the filter pack composed of 10- to 20-mesh silica sand. Bentonite well seals will be completed in such a manner as to isolate the seal from leaking or migrating into the screen interval. The well construction will meet WAC 173-160 requirements.

\subsection{Site-Specific Characterization}

This section covers work elements associated with site-specific characterization of the biostimulation test site. Based on the site-selection criteria discussed in Section 1.2, a preferred test site location for demonstration of the biostimulation technologies has been selected approximately $30 \mathrm{~m}$ downgradient of groundwater monitoring well 199-D5-40 (Figure 1.1). Following installation of the two biostimulation well networks, several hydrogeologic characterization methods will be used to obtain additional site-specific information. Planned activities include 1) collection of baseline groundwater chemistry samples (described in Section 5.5); 2) hydraulic testing to obtain formation hydraulic properties; and 3 ) EBF testing to assess the vertical distribution of horizontal hydraulic conductivity (i.e., vertical heterogeneities). All characterization activities will be conducted in accordance with applicable PNNL procedures (in Standards Based Management Systems [SBMS]) and any investigation-derived waste will be handled in accordance with Hanford Site requirements.

Hydraulic tests as part of site-specific characterization will be conducted as required in the injection wells and monitoring wells to determine the hydraulic properties of the aquifer and the specific capacity of the injection well. Due to investigation-derived waste disposal limitations, this initial hydraulic testing will be limited to well development data and either single-well slug testing or multiwell slug interference testing to provide a semiquantitative estimate of hydraulic properties. These test data will be representative of baseline (preinjection) aquifer conditions and will be incorporated into the design analysis of the pilot-technology demonstration. Hydrologic test data will be analyzed using peer-reviewed analytical or numerical methods that are applicable to the given test conditions. In addition to these standard aquifer testing methods, electromagnetic borehole flowmeter tests will be conducted to assess the vertical distribution of horizontal hydraulic conductivity. Water levels will be monitored in three wells at the test area for the duration of the field test for use in determining the groundwater flow direction via triangulation of the water-level data.

\subsection{Field Test Operations}

This section describes the primary field test operations. Details of these operations are further described in the Sampling and Analysis Plan (Section 6.0) and in project-controlled field test instructions that will be prepared after the treatability test plan is finalized. Field testing for the soluble substrate and the immiscible substrate will be conducted concurrently in general, although specific activities (e.g., substrate injection) will be staggered as needed to accommodate site logistics. 
Test Preparations - Injection equipment, sampling systems, and other necessary field test equipment will be assembled based on the finalized treatability test plan. Figure 5.2 shows a schematic of the conceptual equipment design for the injection. In summary, injection operations will require a source of process water, mixing equipment to add substrate to the water, an injection pump, and a down-well packer system to maintain injection within the screened interval.

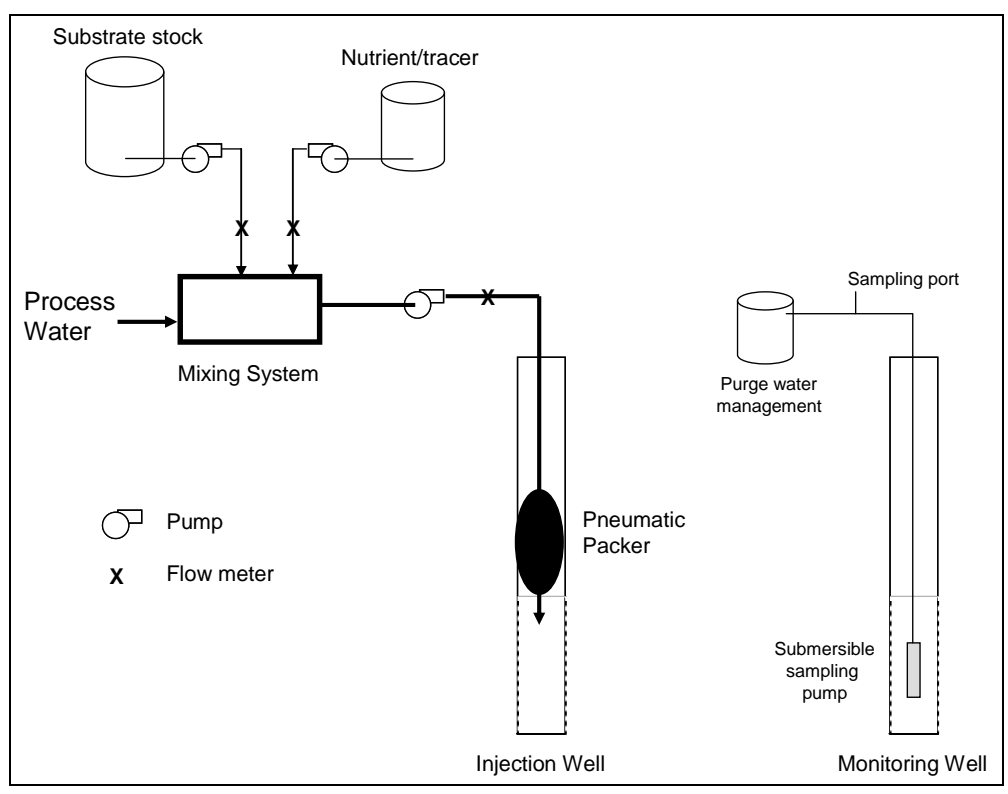

Figure 5.2. Conceptual Test Equipment Schematic

Pretest Monitoring - Before the test injection, hydraulic testing and baseline monitoring will be conducted. Hydraulic testing will include slug interference and recovery testing and electronic borehole flow meter testing in each injection well. Baseline monitoring will include water level measurements via pressure transducer and electric sounding tape at the monitoring well and two injection locations over a period of at least one week. Baseline sample analyses will include TOC, organic acids, nitrate, nitrite, sulfate, chromate, major cations and anions, Resource Conservation and Recovery Act (RCRA) metals, and dissolved oxygen for three samples collected at 1-week intervals at the monitoring well and two injection well locations, at well D5-40 (the upgradient monitoring well), and for the process water.

Substrate Injection: Soluble Substrate - The soluble substrate test cell will be injected first. The injection will be conducted using process water amended with $50 \mathrm{~g} / \mathrm{L}$ molasses, $100 \mathrm{mg} / \mathrm{L}$ ammonium chloride, and $100 \mathrm{mg} / \mathrm{L}$ potassium bromide, or similar concentrations depending on the final design analysis. These concentrations will be obtained based on measured concentrations of the stock solutions for each additive and measurement of the relative flow rate for each additive and the process water. Samples of the injected solution will be collected every 4 hours at a minimum. The injection flow rate will be $190 \mathrm{~L} /$ minute ( $\sim 50 \mathrm{gpm})$ and continue for 66 hours. Process water with no additives will then be injected for 30 minutes at $190 \mathrm{~L} /$ minute to clear the injection piping, injection well, and sand pack of additives. After the injection is completed, the injection system will be disconnected and the injection well will be converted to a monitoring location by lowering a submersible sampling pump through the riser and packer into screened interval. During injection, monitoring wells will be sampled periodically and analyzed for bromide, total organic carbon (TOC), organic acids, nitrate, nitrite, sulfate, and chromate. 
Substrate Injection: Immiscible Substrate - The immiscible substrate will be injected approximately 2 to 4 weeks after the soluble substrate. The injection will be conducted using process water amended with a soybean oil emulsion and $100 \mathrm{mg} / \mathrm{L}$ potassium bromide. The concentration of oil emulsion in the injected water is dependent on the number of pore volumes of water that will be injected as determined in the bench-scale testing. Nominally, initial estimates are based on a total of $\sim 12,000 \mathrm{~L}$ of oil injected to obtain a $1 \mathrm{wt} \%$ residual oil concentration in the aquifer. For one pore volume, this amount of oil in the injected water would be approximately $14 \%$ by volume. The specific emulsion injection procedures will be determined based on bench-scale testing (Section 2.4). The emulsion solution properties will be confirmed by sampling every 2 hours at a minimum during injection. For initial estimates, the injection flow rate will be $76 \mathrm{~L} /$ minute ( $\sim 20 \mathrm{gpm})$ and continue for approximately 18 hours. Process water will then be injected to clear the injection piping, injection well, sand pack, and near-well aquifer of excess emulsion and assist in emulsion distribution as determined in the bench-scale experiments (Section 2.4). After the injection is completed, the injection system will be disconnected and the injection well will be converted to a monitoring location by lowering a submersible sampling pump through the riser and packer into the screened interval. During injection, monitoring wells will be sampled periodically and analyzed for bromide, turbidity, TOC, organic acids, nitrate, nitrite, sulfate, and chromate. Geophysical monitoring will also be conducted to assess the distribution of oil in the aquifer by comparing the before and after injection geophysical surveys as described in Appendix C.

Process Monitoring - Process monitoring will be conducted after injection is completed to assess the formation of a reducing barrier. In the soluble substrate test cell, samples will be collected at each well in the test cell weekly for 8 weeks and analyzed for TOC, organic acids, nitrate, nitrite, sulfate, chromate, oxygen, ORP, bromide, and $\mathrm{pH}$. In the immiscible substrate test cell, the oil distribution will be assessed using geophysical techniques as described in Appendix C. Samples will also be collected weekly for 8 weeks and analyzed for TOC, organic acids, nitrate, nitrite, sulfate, chromate, oxygen, turbidity, ORP, bromide, and $\mathrm{pH}$. If necessary, continued monitoring of substrate drift will be conducted with weekly monitoring of bromide, TOC and turbidity until the drift is fully assessed. To assess the impact of the injected solutions, slug interference and recovery tests and electronic borehole flowmeter tests at each injection well will be conducted at the end of the process monitoring phase.

Performance Monitoring - After the process monitoring phase is completed, the test cells will be monitored to assess performance as a reducing barrier. The goal of this monitoring phase is to evaluate the conditions within the reducing barrier and to determine when nitrate, chromate, and oxygen break through occurs as an indication of barrier longevity. This performance monitoring will consist of samples collected at each well in the test cell and at the upgradient monitoring well (D5-40) on a monthly basis for up to 12 months and potentially longer. Samples will be analyzed for TOC, organic acids, nitrate, nitrite, sulfate, chromate, oxygen, methane, ORP, and $\mathrm{pH}$. Additionally, major cations and anions, RCRA metals, and methane will be monitored every 6 months for comparison to the baseline water quality determined in the pretest monitoring.

\subsection{Equipment and Materials}

This section presents the field equipment and materials needed the treatability test. The conceptual layout of the field site is shown in Figure 5.3. Until the design analysis and field characterization phases of the treatability test are complete, equipment sizes and volumes of material are estimates. 


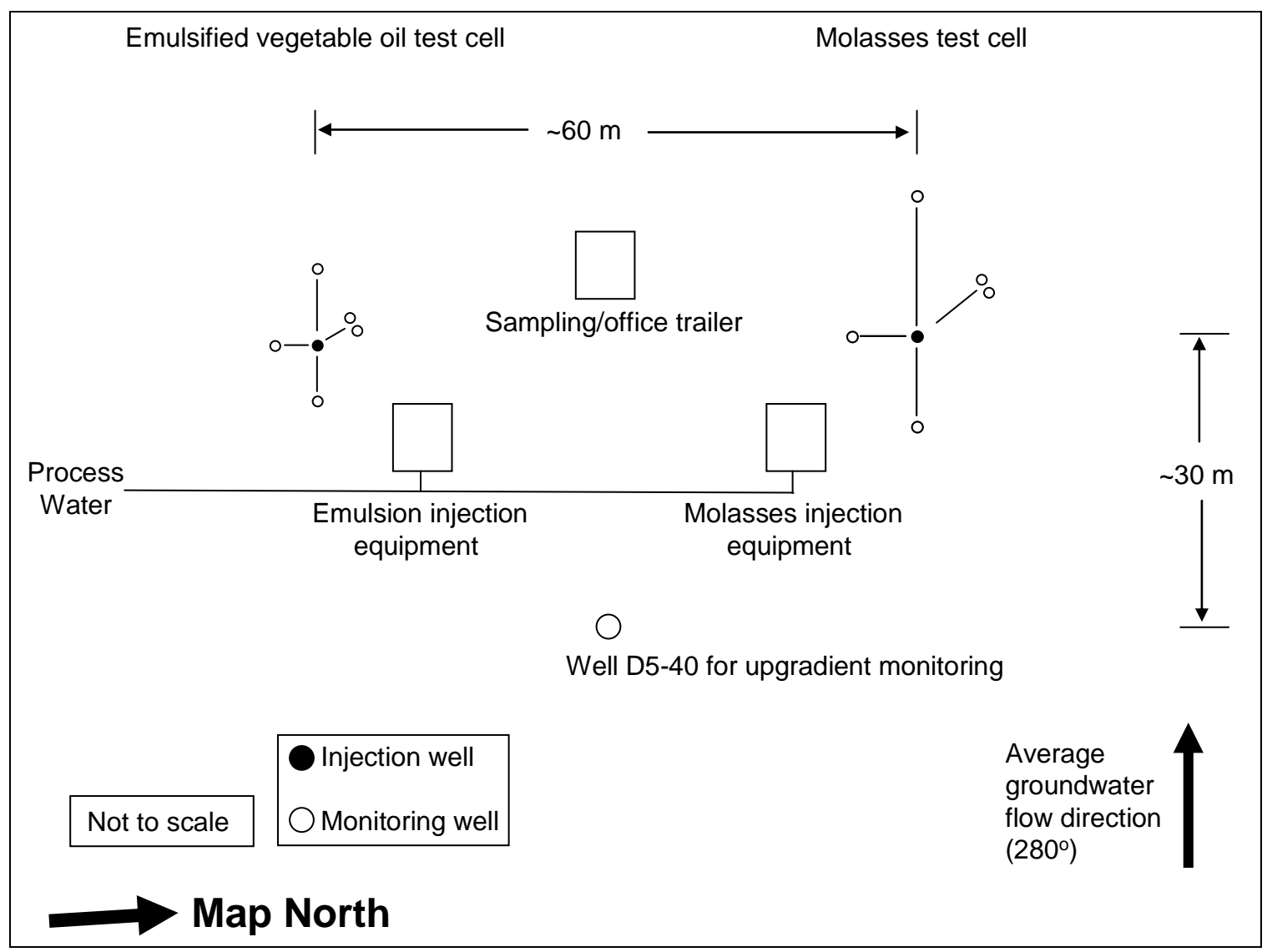

Figure 5.3. Conceptual Site Layout

For the molasses test cell, the following primary equipment will be necessary.

- molasses storage (likely a tanker truck or large tote tanks)

- nutrient/tracer storage tank

- molasses and nutrient/tracer metering pumps

- molasses and nutrient/tracer feed flow meters

- in-line mixer

- process water/injection pump

- injection flow meter

- pneumatic packer

- pressure transducers (4)

- RediFlow submersible sampling pumps and controllers (4).

For the emulsified oil test cell, the following primary equipment will be necessary:

- emulsified vegetable oil stock solution storage (likely a tanker truck or large tote tanks)

- tracer storage tank

- emulsified vegetable oil stock solution and nutrient/tracer metering pumps

- emulsified vegetable oil stock solution and nutrient/tracer feed flow meters

- in-line mixer

- process water/injection pump 
- emulsified vegetable oil stock solution mixing equipment

- injection flow meter

- pneumatic packer

- pressure transducers (4)

- RediFlow submersible sampling pumps and controllers (4).

Equipment jointly used by the test cells includes the following items:

- process water feed

- 208 volts alternating current generator

- purge water storage tank.

\subsection{Chemical Requirements}

Table 5.1 shows the type and quantity of chemicals that will be injected into the subsurface for each of the test cells. These chemicals will be distributed in the subsurface by co-injection with process water obtained from the 100-D Area raw water supply, which is maintained primarily for fire suppression. The process water chemistry will be determined prior to injection, but is not expected to contain any chemicals of concern. The process water will be pretreated to remove oxygen, if necessary based on the results of the laboratory testing, by dosing with a small amount of moderate reducing agent. Injection volumes are based on the anticipated barrier radius of $5 \mathrm{~m}$ for the oil-based barrier and $15 \mathrm{~m}$ for the biostimulation barrier using a barrier height of $7.625 \mathrm{~m}$ and a porosity of 0.14 .

Table 5.1. Chemical Additives for the Treatability Test

\begin{tabular}{||l|c|c||}
\hline \multicolumn{1}{||c|}{ Chemical } & Nominal Concentration & Total Quantity \\
\hline \hline \multicolumn{3}{|c|}{ Soluble Substrate Test Cell } \\
\hline Molasses & $50 \mathrm{~g} / \mathrm{L}$ & $38,000 \mathrm{~L}$ \\
\hline Ammonium Chloride & $100 \mathrm{mg} / \mathrm{L}$ & $75 \mathrm{~kg}$ \\
\hline Potassium Bromide & $100 \mathrm{mg} / \mathrm{L}$ & $75 \mathrm{~kg}$ \\
\hline Process Water & -- & $720,000 \mathrm{~L}$ \\
\hline \multicolumn{2}{|c||}{ Emulsified Vegetable Oil Test Cell } \\
\hline $\begin{array}{l}\text { Emulsified Soybean } \\
\text { Oil/Hydrogenated Soybean } \\
\text { Oil }\end{array}$ & $\begin{array}{c}14 \% \text { by volume } \\
70 \% \text { stock solution }\end{array}$ \\
\hline Potassium Bromide & $100 \mathrm{mg} / \mathrm{L}$ & $75 \mathrm{~kg}$ \\
\hline Process Water & -- & $72,000 \mathrm{~L} / \mathrm{pore}$ volume \\
\hline
\end{tabular}




\subsection{Sampling and Analysis}

This section contains the Sampling and Analysis Plan (SAP). Specific field sampling protocols will be described in project-controlled Field Test Instructions to be developed after the test design has been completed. The work will comply with applicable subject areas of PNNL's SBMS located at https://sbms.pnl.gov. SBMS is a web-based system for communicating PNNL's management systems and procedures through subject areas. PNNL's Quality Assurance Program is based on the requirements of DOE Order 414.1C, Quality Assurance, and 10 CFR 830, Subpart A. Investigation-derived waste will be handled in accordance with Hanford Site requirements.

During all groundwater sampling, field parameters $(\mathrm{pH}$, specific conductance, turbidity, DO, ORP, and T) will be measured and recorded manually on data sheets which will be copied for distribution. Calibration of field probes will follow the manufacturer's instructions using standard calibration solutions. Detailed sampling instructions, including which wells to sample and at what frequency, will be posted in the field site trailer prior to initiation of the test.

Groundwater sample collection requirements and location and frequency of sampling are provided in Table 6.1 and Table 6.2, respectively. All analyses will be performed in accordance analytical requirements listed in Table 6.3.

Table 6.1. Groundwater Chemistry Sampling Requirements

\begin{tabular}{|c|c|c|c|c|c|}
\hline Parameter & $\begin{array}{l}\text { Media/ } \\
\text { Matrix }\end{array}$ & Monitoring Phase & $\begin{array}{l}\text { Volume/ } \\
\text { Container }\end{array}$ & Preservation & $\begin{array}{l}\text { Holding } \\
\text { Time }\end{array}$ \\
\hline \multicolumn{6}{|c|}{ Water Quality Parameters } \\
\hline $\begin{array}{l}\text { Major Cations: } \mathrm{Al}, \mathrm{As}, \\
\mathrm{B}, \mathrm{Ba}, \mathrm{Bi}, \mathrm{Ca}, \mathrm{Co}, \mathrm{Fe}, \mathrm{K}, \\
\mathrm{Mg}, \mathrm{Mn}, \mathrm{Ni}, \mathrm{Zn}, \mathrm{Zr}, \mathrm{P}, \\
\mathrm{Sr}, \mathrm{Na}, \mathrm{Si}, \mathrm{S}, \mathrm{Sb}\end{array}$ & Water & $\begin{array}{l}\text { Pretest Monitoring } \\
\text { Performance Monitoring }\end{array}$ & $\begin{array}{l}20-\mathrm{ml} \text { plastic } \\
\text { vial }\end{array}$ & $\begin{array}{l}\text { Filtered, } \\
\mathrm{HNO}_{3} \text { to } \mathrm{pH}<2\end{array}$ & 60 Days \\
\hline $\begin{array}{l}\text { RCRA/Trace Metals: } \\
\mathrm{Cr}, \mathrm{Cu}, \mathrm{As}, \mathrm{Se}, \mathrm{Mo}, \mathrm{Ag}, \\
\mathrm{Cd}, \mathrm{Pb},{ }^{238} \mathrm{U}\end{array}$ & Water & $\begin{array}{l}\text { Pretest Monitoring } \\
\text { Performance Monitoring }\end{array}$ & $\begin{array}{l}20-\mathrm{ml} \text { plastic } \\
\text { vial }\end{array}$ & $\begin{array}{l}\text { Filtered, } \\
\mathrm{HNO}_{3} \text { to } \mathrm{pH}<2\end{array}$ & 60 Days \\
\hline Anions: $\mathrm{Cl}^{-}, \mathrm{Br}^{-}, \mathrm{PO}_{4}{ }^{3-}$ & Water & $\begin{array}{l}\text { Pre-Test Monitoring } \\
\text { Performance Monitoring }\end{array}$ & $\begin{array}{l}20-\mathrm{ml} \text { plastic } \\
\text { vial }\end{array}$ & $\mathrm{Cool} 4^{\circ} \mathrm{C}$ & 45 Days \\
\hline \multicolumn{6}{|c|}{ Performance Assessment Parameters } \\
\hline Total Organic Carbon & Water & $\begin{array}{l}\text { Pretest Monitoring } \\
\text { Substrate Injection } \\
\text { Process Monitoring } \\
\text { Performance Monitoring }\end{array}$ & $\begin{array}{l}\text { 40-ml amber } \\
\text { vial (VOA vial) }\end{array}$ & $\begin{array}{l}\mathrm{Cool} 4^{\circ} \mathrm{C} \\
\mathrm{HCl} \text { to } \mathrm{pH} 2\end{array}$ & 45 Days \\
\hline Organic Acids & Water & $\begin{array}{l}\text { Pretest Monitoring } \\
\text { Substrate Injection } \\
\text { Process Monitoring } \\
\text { Performance Monitoring }\end{array}$ & $\begin{array}{l}\text { 40-ml amber } \\
\text { vial (VOA vial) }\end{array}$ & $\begin{array}{l}\mathrm{Cool} 4^{\circ} \mathrm{C} \\
\mathrm{HCl} \text { to } \mathrm{pH} 2\end{array}$ & 45 Days \\
\hline
\end{tabular}


Table 6.1. (contd)

\begin{tabular}{|c|c|c|c|c|c|}
\hline Parameter & $\begin{array}{l}\text { Media/ } \\
\text { Matrix }\end{array}$ & Monitoring Phase & $\begin{array}{l}\text { Volume/ } \\
\text { Container }\end{array}$ & Preservation & $\begin{array}{c}\text { Holding } \\
\text { Time }\end{array}$ \\
\hline Methane & Water & Performance Monitoring & $\begin{array}{l}\text { 40-ml amber } \\
\text { vial (VOA vial) }\end{array}$ & $\begin{array}{l}\mathrm{Cool} 4^{\circ} \mathrm{C} \\
\mathrm{HCl} \text { to } \mathrm{pH} 2\end{array}$ & 45 Days \\
\hline $\mathrm{NO}_{2}^{-}, \mathrm{NO}_{3}^{-}, \mathrm{SO}_{4}{ }^{2-}$ & Water & $\begin{array}{l}\text { Pretest Monitoring } \\
\text { Substrate Injection } \\
\text { Process Monitoring } \\
\text { Performance Monitoring }\end{array}$ & $\begin{array}{l}\text { 20-ml plastic } \\
\text { vial }\end{array}$ & $\mathrm{Cool} 4^{\circ} \mathrm{C}$ & 45 Days \\
\hline $\mathrm{Cr}^{+6}$ & Water & $\begin{array}{l}\text { Pretest Monitoring } \\
\text { Substrate Injection } \\
\text { Process Monitoring } \\
\text { Performance Monitoring }\end{array}$ & $\begin{array}{l}20 \text {-ml plastic } \\
\text { vial }\end{array}$ & $\mathrm{Cool} 4^{\circ} \mathrm{C}$ & 45 Days \\
\hline Bromide & Water & $\begin{array}{l}\text { Pretest Monitoring } \\
\text { Substrate Injection } \\
\text { Process Monitoring } \\
\text { Performance Monitoring }\end{array}$ & $\begin{array}{l}\text { 20-ml plastic } \\
\text { vial }\end{array}$ & $\mathrm{Cool} 4^{\circ} \mathrm{C}$ & 45 Days \\
\hline \multicolumn{6}{|c|}{ Parameters Using Field Probes } \\
\hline $\mathrm{pH}$ & Water & $\begin{array}{l}\text { Monitored during each } \\
\text { sampling event }\end{array}$ & \begin{tabular}{|l} 
Field \\
Measurement \\
\end{tabular} & None & N/A \\
\hline Turbidity & Water & $\begin{array}{l}\text { Monitored during each } \\
\text { sampling event }\end{array}$ & $\begin{array}{l}\text { Field } \\
\text { Measurement }\end{array}$ & None & N/A \\
\hline Specific Conductance & Water & $\begin{array}{l}\text { Monitored during each } \\
\text { sampling event }\end{array}$ & $\begin{array}{l}\text { Field } \\
\text { Measurement }\end{array}$ & None & $\mathrm{N} / \mathrm{A}$ \\
\hline Dissolved Oxygen & Water & $\begin{array}{l}\text { Monitored during each } \\
\text { sampling event }\end{array}$ & $\begin{array}{l}\text { Field } \\
\text { Measurement }\end{array}$ & None & N/A \\
\hline $\begin{array}{l}\text { Oxidation-Reduction } \\
\text { Potential }\end{array}$ & Water & $\begin{array}{l}\text { Monitored during each } \\
\text { sampling event }\end{array}$ & $\begin{array}{l}\text { Field } \\
\text { Measurement }\end{array}$ & None & N/A \\
\hline Temperature & Water & $\begin{array}{l}\text { Monitored during each } \\
\text { sampling event }\end{array}$ & $\begin{array}{l}\text { Field } \\
\text { Measurement }\end{array}$ & None & N/A \\
\hline
\end{tabular}


Table 6.2. Sampling Frequency and Location

\begin{tabular}{|c|c|c|c|}
\hline Parameter $^{(\mathbf{a})}$ & $\begin{array}{l}\text { Monitoring } \\
\text { Phase }\end{array}$ & Sampling Location & Sampling Frequency \\
\hline \multirow{2}{*}{$\begin{array}{l}\text { Major Cations: Al, } \\
\mathrm{As}, \mathrm{B}, \mathrm{Ba}, \mathrm{Bi}, \mathrm{Ca} \text {, } \\
\mathrm{Co}, \mathrm{Fe}, \mathrm{K}, \mathrm{Mg}, \\
\mathrm{Mn}, \mathrm{Ni}, \mathrm{Zn}, \mathrm{Zr}, \mathrm{P} \text {, } \\
\mathrm{Sr}, \mathrm{Na}, \mathrm{Si}, \mathrm{S}, \mathrm{Sb}\end{array}$} & $\begin{array}{l}\text { Pretest } \\
\text { Monitoring }\end{array}$ & $\begin{array}{l}\text { Well D5-40, test cell } \\
\text { monitoring wells, test cell } \\
\text { injection wells }\end{array}$ & 1, 2, and 3 weeks before injection \\
\hline & $\begin{array}{l}\text { Performance } \\
\text { Monitoring }\end{array}$ & $\begin{array}{l}\text { Well D5-40, test cell } \\
\text { injection wells }\end{array}$ & 1,6 , and 12 months after injection \\
\hline \multirow{2}{*}{$\begin{array}{l}\text { RCRA/Trace } \\
\text { Metals: } \mathrm{Cr}, \mathrm{Cu}, \\
\mathrm{As}, \mathrm{Se}, \mathrm{Mo}, \mathrm{Ag}, \\
\mathrm{Cd}, \mathrm{Pb},{ }^{238} \mathrm{U}\end{array}$} & $\begin{array}{l}\text { Pretest } \\
\text { Monitoring }\end{array}$ & $\begin{array}{l}\text { Well D5-40, test cell } \\
\text { monitoring wells, test cell } \\
\text { injection wells }\end{array}$ & 1,2 , and 3 weeks before injection \\
\hline & $\begin{array}{l}\text { Performance } \\
\text { Monitoring }\end{array}$ & $\begin{array}{l}\text { Well D5-40, test cell } \\
\text { injection wells }\end{array}$ & 1,6 , and 12 months after injection \\
\hline \multirow[t]{2}{*}{ Anions: $\mathrm{Cl}^{-}, \mathrm{PO}_{4}^{3-}$} & $\begin{array}{l}\text { Pretest } \\
\text { Monitoring }\end{array}$ & $\begin{array}{l}\text { Well D5-40, test cell } \\
\text { monitoring wells, test cell } \\
\text { injection wells }\end{array}$ & 1,2 , and 3 weeks before injection \\
\hline & $\begin{array}{l}\text { Performance } \\
\text { Monitoring }\end{array}$ & $\begin{array}{l}\text { Well D5-40, test cell } \\
\text { injection wells }\end{array}$ & 1,6 , and 12 months after injection \\
\hline Methane & $\begin{array}{l}\text { Performance } \\
\text { Monitoring }\end{array}$ & $\begin{array}{l}\text { Test cell monitoring wells, } \\
\text { test cell injection wells }\end{array}$ & 1,6 , and 12 months after injection \\
\hline \multirow[t]{4}{*}{$\begin{array}{l}\text { Total Organic } \\
\text { Carbon }\end{array}$} & $\begin{array}{l}\text { Pretest } \\
\text { Monitoring }\end{array}$ & $\begin{array}{l}\text { Well D5-40, test injection } \\
\text { wells }\end{array}$ & 1,2 , and 3 weeks before injection \\
\hline & $\begin{array}{l}\text { Substrate } \\
\text { Injection }\end{array}$ & $\begin{array}{l}\text { Injection line, test cell } \\
\text { monitoring wells }\end{array}$ & $\begin{array}{l}\text { Every } 4 \text { hours in injection line (soluble), } \\
\text { every } 2 \text { hours in injection line (immiscible), } \\
\text { every } 4 \text { hours starting } 8 \text { hours before expected } \\
\text { arrival at monitoring wells (soluble), every } 2 \\
\text { hours starting } 4 \text { hours before expected arrival } \\
\text { at monitoring wells (immiscible) }\end{array}$ \\
\hline & $\begin{array}{l}\text { Process } \\
\text { Monitoring }\end{array}$ & $\begin{array}{l}\text { Test cell monitoring wells, } \\
\text { test cell injection wells }\end{array}$ & Weekly for 8 weeks after injection \\
\hline & $\begin{array}{l}\text { Performance } \\
\text { Monitoring }\end{array}$ & $\begin{array}{l}\text { Test cell monitoring wells, } \\
\text { test cell injection wells }\end{array}$ & $\begin{array}{l}\text { Twice per month after end of process } \\
\text { monitoring stage }\end{array}$ \\
\hline \multirow[t]{4}{*}{$\mathrm{NO}_{2}^{-}, \mathrm{NO}_{3}^{-}, \mathrm{SO}_{4}^{2-}$} & $\begin{array}{l}\text { Pretest } \\
\text { Monitoring }\end{array}$ & $\begin{array}{l}\text { Well D5-40, test cell } \\
\text { monitoring wells, test cell } \\
\text { injection wells }\end{array}$ & 1,2, and 3 weeks before injection \\
\hline & $\begin{array}{l}\text { Substrate } \\
\text { Injection }\end{array}$ & Test cell monitoring wells & $\begin{array}{l}\text { Every } 4 \text { hours in injection line (soluble), } \\
\text { every } 2 \text { hours in injection line (immiscible), } \\
\text { every } 4 \text { hours starting } 8 \text { hours before expected } \\
\text { arrival at monitoring wells (soluble), every } 2 \\
\text { hours starting } 4 \text { hours before expected arrival } \\
\text { at monitoring wells (immiscible) }\end{array}$ \\
\hline & $\begin{array}{l}\text { Process } \\
\text { Monitoring }\end{array}$ & $\begin{array}{l}\text { Well D5-40, test cell } \\
\text { monitoring wells, test cell } \\
\text { injection wells }\end{array}$ & Weekly for 8 weeks after injection \\
\hline & $\begin{array}{l}\text { Performance } \\
\text { Monitoring }\end{array}$ & $\begin{array}{l}\text { Well D5-40, test cell } \\
\text { monitoring wells, test cell } \\
\text { injection wells }\end{array}$ & $\begin{array}{l}\text { Twice per month after end of process } \\
\text { monitoring stage }\end{array}$ \\
\hline
\end{tabular}


Table 6.2. (contd)

\begin{tabular}{|c|c|c|c|}
\hline Parameter ${ }^{(a)}$ & $\begin{array}{l}\text { Monitoring } \\
\text { Phase }\end{array}$ & Sampling Location & Sampling Frequency \\
\hline \multirow[t]{4}{*}{$\mathrm{Cr}^{+6}$} & $\begin{array}{l}\text { Pretest } \\
\text { Monitoring }\end{array}$ & $\begin{array}{l}\text { Well D5-40, test cell } \\
\text { monitoring wells, test cell } \\
\text { injection wells }\end{array}$ & 1,2, and 3 weeks before injection \\
\hline & $\begin{array}{l}\text { Substrate } \\
\text { Injection }\end{array}$ & Test cell monitoring wells & $\begin{array}{l}\text { Every } 4 \text { hours in injection line (soluble), } \\
\text { every } 2 \text { hours in injection line (immiscible), } \\
\text { every } 4 \text { hours starting } 8 \text { hours before expected } \\
\text { arrival at monitoring wells (soluble), every } 2 \\
\text { hours starting } 4 \text { hours before expected arrival } \\
\text { at monitoring wells (immiscible) }\end{array}$ \\
\hline & $\begin{array}{l}\text { Process } \\
\text { Monitoring }\end{array}$ & $\begin{array}{l}\text { Well D5-40, test cell } \\
\text { monitoring wells, test cell } \\
\text { injection wells }\end{array}$ & Weekly for 8 weeks after injection \\
\hline & $\begin{array}{l}\text { Performance } \\
\text { Monitoring }\end{array}$ & $\begin{array}{l}\text { Well D5-40, test cell } \\
\text { monitoring wells, test cell } \\
\text { injection wells }\end{array}$ & $\begin{array}{l}\text { Twice per month after end of process } \\
\text { monitoring stage }\end{array}$ \\
\hline \multirow[t]{4}{*}{ Bromide } & $\begin{array}{l}\text { Pretest } \\
\text { Monitoring }\end{array}$ & $\begin{array}{l}\text { Well D5-40, test injection } \\
\text { wells }\end{array}$ & 1,2 , and 3 weeks before injection \\
\hline & $\begin{array}{l}\text { Substrate } \\
\text { Injection }\end{array}$ & $\begin{array}{l}\text { Injection line, test cell } \\
\text { monitoring wells }\end{array}$ & $\begin{array}{l}\text { Every } 4 \text { hours in injection line (soluble), } \\
\text { every } 2 \text { hours in injection line (immiscible), } \\
\text { every } 4 \text { hours starting } 8 \text { hours before expected } \\
\text { arrival at monitoring wells (soluble), every } 2 \\
\text { hours starting } 4 \text { hours before expected arrival } \\
\text { at monitoring wells (immiscible) }\end{array}$ \\
\hline & $\begin{array}{l}\text { Process } \\
\text { Monitoring }\end{array}$ & $\begin{array}{l}\text { Test cell monitoring wells, } \\
\text { test cell injection wells }\end{array}$ & Weekly for 8 weeks after injection \\
\hline & $\begin{array}{l}\text { Performance } \\
\text { Monitoring }\end{array}$ & $\begin{array}{l}\text { Test cell monitoring wells, } \\
\text { test cell injection wells }\end{array}$ & $\begin{array}{l}\text { Twice per month after end of process } \\
\text { monitoring stage }\end{array}$ \\
\hline \multirow[t]{4}{*}{ Organic Acids } & $\begin{array}{l}\text { Pretest } \\
\text { Monitoring }\end{array}$ & $\begin{array}{l}\text { Well D5-40, test injection } \\
\text { wells }\end{array}$ & 1,2, and 3 weeks before injection \\
\hline & $\begin{array}{l}\text { Substrate } \\
\text { Injection } \\
\end{array}$ & $\begin{array}{l}\text { Test cell monitoring wells, } \\
\text { test cell injection wells }\end{array}$ & End of substrate injection \\
\hline & $\begin{array}{l}\text { Process } \\
\text { Monitoring } \\
\end{array}$ & $\begin{array}{l}\text { Test cell monitoring wells, } \\
\text { test cell injection wells }\end{array}$ & Weekly for 8 weeks after injection \\
\hline & $\begin{array}{l}\text { Performance } \\
\text { Monitoring }\end{array}$ & $\begin{array}{l}\text { Test cell monitoring wells, } \\
\text { test cell injection wells }\end{array}$ & $\begin{array}{l}\text { Twice per month after end of process } \\
\text { monitoring stage }\end{array}$ \\
\hline $\begin{array}{l}\text { (a) Parameters } \\
\text { wells at eac }\end{array}$ & $\begin{array}{l}\text { field probes } \mathrm{W} \\
\text { apling event. }\end{array}$ & measured at well D5-40, te & st cell monitoring wells, and test cell injection \\
\hline
\end{tabular}


Table 6.3. Analytical Requirements

\begin{tabular}{|c|c|c|c|c|}
\hline Parameter & Analysis Method & $\begin{array}{l}\text { Detection Limit } \\
\text { or (Range) }\end{array}$ & $\begin{array}{l}\text { Typical } \\
\text { Precision/ } \\
\text { Accuracy }\end{array}$ & QC Requirements \\
\hline $\begin{array}{l}\text { Major } \\
\text { Cations/Metals: } \\
\mathrm{Ca}, \mathrm{Fe}, \mathrm{K}, \mathrm{Mg}, \mathrm{P}, \mathrm{Na} \text {, } \\
\mathrm{Si}, \mathrm{S}, \mathrm{Al}, \mathrm{B}, \mathrm{Ba}, \mathrm{Bi} \text {, } \\
\mathrm{Ni}, \mathrm{Zn}, \mathrm{Zr}, \mathrm{Sr}\end{array}$ & $\begin{array}{l}\text { ICP-OES, PNNL-AGG- } \\
\text { ICP-AES (similar to } \\
\text { EPA Method 6010B) }\end{array}$ & \begin{tabular}{|l}
$1 \mathrm{mg} / \mathrm{L}$ \\
$0.1 \mathrm{mg} / \mathrm{L}$
\end{tabular} & $\pm 10 \%$ & $\begin{array}{l}\text { Daily calibration; blanks } \\
\text { and duplicates and matrix } \\
\text { spikes at } 10 \% \text { level per } \\
\text { batch of } 20 .\end{array}$ \\
\hline $\begin{array}{l}\text { RCRA / Trace } \\
\text { Metals: } \\
\mathrm{Cr}, \mathrm{Cu}, \mathrm{As}, \mathrm{Se}, \mathrm{Mo}, \\
\mathrm{Ag}, \mathrm{Cd}, \mathrm{Pb},{ }^{238} \mathrm{U} \\
\end{array}$ & $\begin{array}{l}\text { ICP-MS, PNNL-AGG- } \\
415 \text { (similar to EPA } \\
\text { Method 6020) }\end{array}$ & $\begin{array}{l}1 \mu \mathrm{g} / \mathrm{L} \text { for trace } \\
\text { elements }\end{array}$ & $\pm 10 \%$ & $\begin{array}{l}\text { Daily calibration; blanks } \\
\text { and duplicates and matrix } \\
\text { spikes at } 10 \% \text { level per } \\
\text { batch of } 20 .\end{array}$ \\
\hline $\begin{array}{l}\text { Anions: } \mathrm{Cl}^{-}, \mathrm{Br}, \\
\mathrm{PO}_{4}^{-3}\end{array}$ & \begin{tabular}{|l|} 
Ion Chromatography, \\
AGG-IC-001 (based on \\
EPA Method 300.0A) \\
\end{tabular} & $1 \mathrm{mg} / \mathrm{L}$ & $\pm 15 \%$ & $\begin{array}{l}\text { Daily calibration; blanks } \\
\text { and duplicates at } 10 \% \text { level } \\
\text { per batch of } 20 .\end{array}$ \\
\hline Methane & RSKSOP-175 & $0.01 \mathrm{mg} / \mathrm{L}$ & $\pm 15 \%$ & $\begin{array}{l}\text { Daily calibration; blanks } \\
\text { and duplicates at } 10 \% \text { level } \\
\text { per batch of } 20 .\end{array}$ \\
\hline TOC & $\begin{array}{l}\text { TOC Analyzer, Method } \\
\text { 9060A }\end{array}$ & $1 \mathrm{mg} / \mathrm{L}$ & $\pm 15 \%$ & $\begin{array}{l}\text { Daily calibration; blanks } \\
\text { and duplicates at } 10 \% \text { level } \\
\text { per batch of } 20 .\end{array}$ \\
\hline Organic Acids & HPLC & $1 \mathrm{mg} / \mathrm{L}$ & $\pm 15 \%$ & $\begin{array}{l}\text { Daily calibration; blanks } \\
\text { and duplicates at } 10 \% \text { level } \\
\text { per batch of } 20 .\end{array}$ \\
\hline $\mathrm{NO}_{2}^{-}, \mathrm{NO}_{3}^{-}, \mathrm{SO}_{4}^{2-}$ & $\begin{array}{l}\text { Ion Chromatography, } \\
\text { AGG-IC-001 (based on } \\
\text { EPA Method 300.0A) }\end{array}$ & $1 \mathrm{mg} / \mathrm{L}$ & $\pm 15 \%$ & $\begin{array}{l}\text { Daily calibration; blanks } \\
\text { and duplicates at } 10 \% \text { level } \\
\text { per batch of } 20 .\end{array}$ \\
\hline $\mathrm{Cr}^{+6}$ & Hach 59573-88 & $0.01 \mathrm{mg} / \mathrm{L}$ & $\begin{array}{l} \pm 0.01 \mathrm{mg} / \mathrm{L} \text { at } \\
0.25 \mathrm{mg} / \mathrm{L}\end{array}$ & $\begin{array}{l}\text { Follow manufacturer } \\
\text { recommendations }\end{array}$ \\
\hline Bromide & Ion selective electrode & $\begin{array}{l}(0.4 \text { to } \\
79,900 \mathrm{mg} / \mathrm{L})\end{array}$ & $\begin{array}{l}\text { For indication } \\
\text { only }\end{array}$ & $\begin{array}{l}\text { Follow manufacturer } \\
\text { recommendations }\end{array}$ \\
\hline $\mathrm{pH}$ & pH electrode & ( 2 to 12 units) & $\pm 0.2 \mathrm{pH}$ unit & $\begin{array}{l}\text { User calibrate, follow } \\
\text { manufacturer } \\
\text { recommendations }\end{array}$ \\
\hline Turbidity & NTU meter & \begin{tabular}{|l|} 
TBD for \\
correlation to \\
emulsion \\
\end{tabular} & $\begin{array}{l}\text { For indication } \\
\text { only }\end{array}$ & $\begin{array}{l}\text { User calibrate, follow } \\
\text { manufacturer } \\
\text { recommendations }\end{array}$ \\
\hline Specific conductance & Electrode & $(0$ to $100 \mathrm{mS} / \mathrm{cm})$ & $\pm 1 \%$ of reading & $\begin{array}{l}\text { User calibrate, follow } \\
\text { manufacturer } \\
\text { recommendations }\end{array}$ \\
\hline Dissolved oxygen & Membrane electrode & $(0$ to $20 \mathrm{mg} / \mathrm{L})$ & $\pm 0.2 \mathrm{mg} / \mathrm{L}$ & $\begin{array}{l}\text { User calibrate, follow } \\
\text { manufacturer } \\
\text { recommendations }\end{array}$ \\
\hline $\begin{array}{l}\text { Oxidation-Reduction } \\
\text { Potential }\end{array}$ & Electrode & $(-999$ to $999 \mathrm{mV})$ & $\pm 20 \mathrm{mV}$ & $\begin{array}{l}\text { User calibrate, follow } \\
\text { manufacturer } \\
\text { recommendations }\end{array}$ \\
\hline Temperature & Thermocouple & $\left(-5\right.$ to $\left.50^{\circ} \mathrm{C}\right)$ & $\pm 0.2^{\circ} \mathrm{C}$ & Factory calibration \\
\hline
\end{tabular}




\subsection{Data Management}

A project-specific database will be developed and maintained to collect, organize, store, verify/ validate, and manage analytical laboratory data and/or field measurements for environmental samples. The data will be stored electronically in Microsoft Excel spreadsheets and paper copies will be maintained in the project files. Further data management methods for electronic files are discussed in Section 8.5. A project data custodian will be designated to control and maintain the data. The following data will be contained, at a minimum, as part of the database:

- sample identifier

- sample location

- sample medium type

- sampling date

- analysis date

- laboratory name

- analyte name

- concentration value

- measurement unit. 


\subsection{Data Analysis and Interpretation}

Detailed discussions of the planned tests and sampling are found in Sections 5.0 and 6.0. This section describes the plan for the analysis of the performance monitoring data. The planned performance monitoring and testing program includes the following:

- Establish pretest and upgradient nitrate, chromate, oxygen, water quality, and aquifer characteristics at the test site to enable interpretation of biobarrier performance

- Determine the impact of the biostimulation barrier on hydraulic properties of the aquifer using preand post-barrier installation hydrologic testing at the site.

- Perform routine performance monitoring of nitrate, nitrite, chromate, oxygen, and water quality at the test site for evaluation of biobarrier performance

- Conduct tracer tests, groundwater monitoring, and geophysical testing to evaluate distribution of substrates used to install the biostimulation barriers

- Collect aqueous samples on a periodic basis to assess longevity of the reducing zone and any impacts to water quality

- Collect sediment during installation of the injection wells for bench-scale tests to support design of the substrate injection and provide information to help interpret reaction kinetics and barrier longevity.

This section describes the analysis of data to interpret the performance of the biostimulation barriers. The analysis can be viewed in terms of assessing barrier performance in four areas of functionality:

1. laboratory-scale performance

2. injection performance

3. barrier performance and longevity

4. side effects (i.e., quantify the effect the treatment zone has on the chemistry of the aquifer).

These performance areas are discussed in Sections 8.1 through 8.4. Software and associated quality assurance associated with data analysis during all phases of the project is discussed in Section 8.5.

\subsection{Laboratory- and Bench-Scale Performance}

The assessment of laboratory-scale performance will be based on the observed stoichiometric and kinetic parameters associated with the processes required for a successful biostimulation reducing barrier. The laboratory test is designed to determine these parameters under controlled conditions. Scale-up relations and numerical modeling will be used to translate these parameters to assess processes at the field scale. Uniform substrate injection and biomass distribution and reduction of nitrate/nitrite, chromate, and oxygen to less than $1,0.022$, and $0.5 \mathrm{mg} / \mathrm{L}$, respectively, will be the goals against which observed/calculated performance are assessed. 
Specifically for the soluble substrate, kinetics of substrate utilization and yield are important to quantify the injection process and formation of the barrier. The subsequent endogenous decay rate and reduction rate for nitrate, chromate, and oxygen are important to quantify the longevity and performance of the barrier in terms of the reduction in concentration of the target compounds in the barrier. The laboratory tests will quantify these parameters using the experimental matrix described in the laboratory test plan (Appendix A).

For the immiscible substrate, performance during injection is related to emulsion transport and is not directly addressed in the laboratory tests (bench testing of emulsion transport has been proposed to provide this information). Once emplaced, the immiscible substrate barrier longevity and performance are related to the longevity of the substrate (e.g., dissolution and consumption rates) and the related reduction rate for nitrate, chromate, and oxygen. The laboratory tests will quantify these parameters using the experimental matrix described in the laboratory test plan (Appendix A).

Additionally, bench-scale tests will be conducted to determine the appropriate site-specific emulsion preparation and injection parameters for the immiscible substrate (Appendix B). Goals for the benchscale test are to establish an emulsion that remains stable under all conditions of the field test (storage, mixing, well injection, and transport in the subsurface), determine the emulsion droplet size for effective distribution in the expected sediment size fractions in the porous media per the methods to meet the emulsion transport design parameters outlined by Soo and Radke (1986) and Soo et al. (1986), and demonstrate effective emulsion distribution within a flow cell as determined by a uniform distribution of residual oil saturation near $1 \mathrm{wt} \%$.

\subsection{Injection Performance}

Spatial distribution of substrate will be assessed using a conservative tracer injected with the substrate, monitoring at three radial locations around the injection well for substrate (TOC), tracer, nitrate, chromate, and oxygen, and for the immiscible substrate, geophysical survey before and after injection. The uniformity and radial distance of injection are the key parameters for the assessment. A radial injection distance of 5 and $15 \mathrm{~m}$ are the goals for the immiscible and soluble substrates, respectively.

\subsection{Barrier Performance and Longevity}

The extent and longevity of reduction in the barrier will be assessed using periodic monitoring of nitrate, nitrite (a denitrification intermediate), chromate, and oxygen at wells located varying distances from the upgradient edge of the barrier and from the injection well. Reduction of nitrate/nitrite, chromate, and oxygen to less than $1,0.022$, and $0.5 \mathrm{mg} / \mathrm{L}$, respectively, will be the goals against which observed/calculated performance are assessed. Longevity will be assessed based on the breakthrough of nitrate, chromate, and oxygen at the monitoring locations with a target of 5- and 1-year total barrier longevity for the immiscible and soluble substrates, respectively.

\subsection{Side Effects}

Side effects include potential plugging of the aquifer, changes in aquifer water quality, and mobilization of trace metals. 
Aquifer plugging will be assessed by comparing the results of aquifer hydraulic characteristic tests before and after emplacement of the barrier. Hydraulic head, hydraulic conductivity, and storativity estimates will be compared to quantify any changes in hydraulic properties caused by barrier emplacement.

Concentrations of key parameters will be measured in the aquifer to assess the effect of the treatment zone on the aquifer chemistry. Nitrate, nitrite, chromate, $\mathrm{pH}$, dissolved oxygen, conductivity, sulfate/sulfite, ICP metals, and concentrations of specific anions will be measured as water quality parameters before the test, and upgradient and within the barrier during the test.

\subsection{Software}

The following sections describe the software being used for data storage, manipulation, and evaluation for this project and associated quality assurance requirements and procedures.

\subsubsection{Description of Software for the Project}

Table 8.1 describes the software, its category and how it will be used for the project. Further details regarding the Groundwater Modeling System software are provided in section 8.5.2 because there is a configurable component for the modeling effort with this software. Details of Excel software are not necessary because only standard functioning of Excel is required.

Table 8.1. Project Software

\begin{tabular}{|l|l|l||}
\hline \multicolumn{1}{|c|}{ Software } & \multicolumn{1}{c|}{ Software Category } & \multicolumn{1}{c|}{ Use in Project } \\
\hline \hline $\begin{array}{l}\text { Microsoft Office } \\
\text { Excel }{ }^{\circledR} 2003\end{array}$ & Acquired (Level C) & $\begin{array}{l}\text { Calculations to support test design, analysis } \\
\text { and presentation of laboratory and field data }\end{array}$ \\
\hline $\begin{array}{l}\text { Groundwater } \\
\text { Modeling System } \\
(\text { GMS }) \text { version } 6.0\end{array}$ & $\begin{array}{l}\text { Acquired (Level C) with a } \\
\text { configurable component } \\
\text { (reaction module) }\end{array}$ & $\begin{array}{l}\text { Reactive transport scoping simulations for test } \\
\text { design and evaluation of test results }\end{array}$ \\
\hline
\end{tabular}

\subsubsection{Groundwater Modeling System Software Requirements}

Risk Management. All software risk associated with GMS is addressed by this test plan (Table 8.2).

Configuration Management. Documentation of the GMS version number used for the modeling effort is sufficient configuration management for the purposes of this project. The GMS project file generates with each model configuration a unique identifier that serves for configuration identification in conjunction with the GMS version number.

Acquired or configurable software used for the storage, manipulation, and evaluation of data that could result in a significant misinterpretation of results or substandard remedial design will be subjected to the following data management procedures:

- Once data have been finalized, the file custodian will add ".final" to the file name and add an internal note that includes the custodian's name and the date the file was finalized. 
Table 8.2. Software Risk Management Description

\begin{tabular}{|c|c|c|}
\hline Specific Risk & Risk Description & Level of Risk \\
\hline $\begin{array}{l}\text { Customer Use of Results } \\
\text { Generated from Software }\end{array}$ & $\begin{array}{l}\text { Project results have tactical impact on customer's business } \\
\text { decisions }\end{array}$ & Low Risk \\
\hline Mitigation of Risk & \multicolumn{2}{|c|}{$\begin{array}{l}\text { The SBMS Safety Software subject area will apply while performing work } \\
\text { associated with the software use. } \\
\text { Peer reviews of the results and reports delivered to the client will take place. } \\
\text { Verification and validation, for its intended use, will be performed on the software } \\
\text { applications used to calculate the results being provided. } \\
\text { Data will be managed to control the data used and control changes made to the data } \\
\text { during results development. } \\
\text { PNNL employees are familiar with the work being performed and are familiar with } \\
\text { the client expectations. } \\
\text { Configurable components of the software will be identified and specific } \\
\text { configurations documented so results could be reproduced if necessary. }\end{array}$} \\
\hline Software (Deliverables) & No software is delivered to the customer. & Not Applicable \\
\hline Mitigation of Risk & \multicolumn{2}{|l|}{ Not applicable. } \\
\hline Software being Used & Software is acquired. & Medium \\
\hline Mitigation of Risk & \multicolumn{2}{|c|}{$\begin{array}{l}\text { The SBMS Safety Software subject area will apply while performing work } \\
\text { associated with the software use. } \\
\text { Groundwater Modeling System (GMS) version } 6.0 \text { is a product of EMS-I. } \\
\text { Verification and validation, for its intended use, will be performed on the software } \\
\text { applications used to calculate the results being provided. }\end{array}$} \\
\hline
\end{tabular}

- The final version will be routed to at least one other project team member for a technical review and an internal note will be included in the file documenting this technical review.

- All final data will be archived along with the final report using a folder structure consistent with the section numbering used in the report.

Procurement Supplier Management. Not applicable: GMS software and associated upgrades are currently in use at PNNL.

Requirement Specifications. The GMS software functionality is to provide the input/output framework and the numerical codes for fate and transport analysis of dissolved species in groundwater. The framework provides a modeling "project" format so that all input, output, and analysis codes associated with a modeling effort are organized, correct for the numerical code, and stored as a unit.

System Design. The standard GMS framework and numerical codes are a sufficient system design for the required modeling. A site-specific reaction module will be configured to reflect the reactions that are appropriate for the modeling work on this project. Quality assurance for this configured reaction module is discussed under the verification and validation section below.

Implementation Plan. The GMS software will be implemented using the standard procedures defined by the software documentation. 
Software Safety. There are no issues with software safety for this modeling effort.

Verification and Validation Plan. The following reaction module test procedures will be implemented to verify and validate correct functioning of the configurable reaction module. This information will be documented in the project files and, as appropriate, in project reports. Interface of the reaction module as a subroutine in the numerical code is standardized as a part of the GMS software and does not need to be tested. The reaction module testing will focus on assessing that the reaction formulas entered into the module provide the expected results under known conditions and mass balance is maintained in the computations.

Reaction Formula Verification - Reaction formulas will be tested using hypothetical test problems for which a known outcome can be independently computed. For instance, molar yields of product from reactants can be independently computed for specified initial conditions and reaction parameter values.

Computational Mass Balance - Testing of the reaction module will be performed in batch mode which solves the reaction equations, but does not include advection, dispersion, and source/sink effects. Changes in the concentration of reactant and product compounds will be output as a function of time to ensure that a mass balance is being maintained in the calculations. The mass balance will be assessed by ensuring that the sum of the reactants and products on a molar basis is equal to the initial molar amount of reactant for all time points. 


\subsection{Health and Safety}

Safety and health issues relating to the treatability test are addressed in site-specific safety documents that identify both radiological and industrial safety and health hazards, as well as control measures for those hazards. Safety documents include specific training requirements for all site workers and visitors. Job-specific health and safety plans covering drilling activities will be prepared by Fluor Hanford, Inc. personnel. PNNL will develop a health and safety plan covering field testing activities associated with the Biostimulation Treatability Study. 


\subsection{Quality Assurance}

The work will comply with applicable subject areas of PNNL's SBMS, a web-based system for communicating PNNL's management systems and procedures through subject areas. PNNL's Quality Assurance Program is based on the requirements of DOE Order 414.1C and 10 CFR 830, Subpart A.

Additional specific quality assurance (QA) requirements are provided in The Columbia River Protection Supplemental Technologies Quality Assurance Project Plan (PNNL 2007). 


\subsection{Waste Management}

All investigation-derived waste will be handled in accordance with PNNL waste management procedures and applicable Hanford Site requirements. Expected waste streams may include the following:

- Miscellaneous solid waste such as filters, wipes, gloves and other personal protective equipment, cloth, sampling and measuring equipment, pumps, pipe, wire, or plastic sheeting

- Purgewater generated during groundwater sampling and hydraulic testing

- Decontamination solutions.

Miscellaneous solid waste that has contacted potentially contaminated groundwater will be segregated from other materials and will be transported to PNNL facilities for disposal based on a waste designation per internal PNNL waste management procedures. Waste will be designated in accordance with WAC 173-303, "Dangerous Waste Regulations" using a combination of process knowledge, historical analytical data, and analyses of samples collected from the site.

Based on historical data from nearby monitoring well 199-D5-40, the hazardous waste designation for $\mathrm{Cr}(\mathrm{VI})$ (D007 at $5 \mathrm{mg} / \mathrm{L}$ ), which is the only constituent identified in local groundwater plumes likely to trigger a hazardous waste designation, does not apply since the historic high $\mathrm{Cr}(\mathrm{VI})$ concentration observed at this location is only $0.4 \mathrm{mg} / \mathrm{L}$.

All generated purgewater and decontamination water will be handled in accordance with Hanford Site requirements.

Spill Containment/Control. The molasses and vegetable oil will arrive on site via tanker trucks. A walk down of the truck will be initiated prior to acceptance of the tank for any leak points. After the tanker is accepted, the tanker will be positioned in the designated locations. An inventory of spill clean up equipment and materials shall be maintained on site. These will include shovels, absorbents, containers, plastic bags, wipes, and large plastic sheets or tarps. Should a leak occur after acceptance of the tanker, the PNNL field lead engineer or PNNL technical representative shall be notified and measures shall be taken to remedy the leak and minimize the spill as practical.

Spill Control and Containment Supplies. Table 11.1 lists spill kits and spill control equipment that will be maintained at the field test site.

Table 11.1. Spill Kits and Spill Control Equipment

\begin{tabular}{|c|c|c||}
\hline Type & Location & Capability \\
\hline \hline Absorbent & Inside spill-control drum & Absorb small quantity spills \\
\hline Plastic bags and tape & Inside spill control drum & Collection of material \\
\hline Plastic sheet or tarp & PNNL laboratory trailer & $\begin{array}{c}\text { Used to collect molasses or } \\
\text { vegetable oil if a leak occurs }\end{array}$ \\
\hline
\end{tabular}




\subsection{National Environmental Policy Act Values}

In accordance with DOE Order 451.1B and the National Environmental Policy Act (NEPA) (42 USC 4321), DOE CERCLA documents are to incorporate NEPA values to the extent practicable. NEPA values, such as analysis of cumulative offsite ecological and socioeconomic impacts; description of the affected environment (including meteorology, hydrology, geology, cultural and ecological resources, and land use); short-term and long-term impacts on human health and the environment; emissions to air and water; and cost are typically included in CERCLA feasibility study. Compliance with ARARs for this treatability test is discussed in Section 4.0.

Several NEPA values common to all of the 100 Area operable units, including laws and guidelines, are addressed in the 100 Area Feasibility Study Phases 1 and 2 (DOE 1993). NEPA values associated with ISRM treatability test were evaluated in the 100-HR-3 Operable Unit Focused Feasibility Study (DOE 1995).

NEPA values specific to the biostimulation project are as follows:

- Cultural and ecological resources reviews were performed in the area where the in situ test is to occur. Because this area has been previously disturbed, no cultural resources are reported or anticipated with the project area.

- Particulate releases to the atmosphere would be limited to fugitive dust emissions that might occur as a result of the proposed activities (e.g., movement of vehicles and equipment). The Columbia River is located at least $400 \mathrm{~m}$ from the proposed the test area; reasonable care in activities will minimize the chance of the river becoming a consequential pathway for particulates.

- Droplet releases might result from the use of uncontaminated water, which would be applied as necessary to mitigate dust during the well installations and construction of the biostimulation test.

- Removal, storage, and disposal of waste would be in accordance with applicable federal and state regulations and guidelines and would not impact employees or the environment.

- The proposed activity will be conducted within the upper unconfined aquifer beneath the Hanford 100 Area. The targeted subsurface interval consists of unconsolidated gravel-dominated sediments of the Ringold fm. and is contaminated with chromium at levels above drinking water standards.

- The proposed activity is more than $0.4 \mathrm{~km}$ from the Columbia River. The Hanford Reach Study Act (Public Law 100-605, as amended) requires notification of the National Park Service of the U.S. Department of the Interior if the project is to be conducted within $0.4 \mathrm{~km}$ of the Columbia River. Since the project is beyond the $0.4 \mathrm{~km}$ limit, the notification is not necessary.

- The biostimulation project represents a small fraction of the total Hanford budget. Therefore, the project is not expected to impact socioeconomics of the Tri-Cities or other parts of Benton and Franklin Counties.

- The project staff and materials associated with the biostimulation project would not significantly impact transportation in the area. 


\subsection{Reports}

A test report summarizing the results of the treatability test will be prepared. The format of the report will be based on the suggested outline for treatability test reports provided in the Guide for Conducting Treatability Studies Under CERCLA (EPA 1992). An annual report on the status of the project will also be prepared and provided to the regulatory agencies at the end of each fiscal year (i.e., September 30). 


\subsection{Schedule}

The schedule of project activities associated with the field test is shown in Figure 14.1. This schedule reflects a change to the original project schedule in that the field testing for the emulsified vegetable oil substrate will be conducted during the late summer of 2008 rather than in 2007 . The schedule change was to allow sufficient time for the bench scale test and associated emulsified oil injection design to be conducted after receipt of the sediment samples required for this effort. The timing of the field test must consider the influence of the Columbia River on the field test site. Even though the test site is over $300 \mathrm{~m}$ from the shore, the river stage still influences the groundwater flow direction at the site. Because of the test site well configuration, and other reasons, the test needs to be conducted during a period when the groundwater is flowing towards the river. A six month period with the groundwater flow direction remaining constant is also required to monitor the results of the injection test. These constraints, in addition to weather related issues in the winter, essentially limit the test window to the late summer to mid-fall period. Thus, the molasses test can be conducted during the summer of 2007 because the necessary laboratory testing and associated injection design can be completed by September 2007 . Because the bench scale test and associated emulsified oil injection design cannot be completed in time for a summer/fall 2007 field test, the emulsified oil field test has been scheduled for summer 2008 .

\begin{tabular}{|c|c|c|c|c|c|c|c|c|c|c|c|c|c|c|c|c|c|c|c|c|c|c|c|c|c|c|c|c|}
\hline \multirow[b]{2}{*}{ Activity Name } & \multirow[b]{2}{*}{$\begin{array}{l}\text { Start } \\
\text { Date }\end{array}$} & \multirow[b]{2}{*}{$\begin{array}{c}\text { Finish } \\
\text { Date }\end{array}$} & \multicolumn{8}{|c|}{2007} & \multicolumn{10}{|c|}{2008} & \multicolumn{8}{|c|}{2009} \\
\hline & & & M & $\mathrm{J}$ & $\mathrm{J}$ & 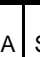 & $\mathrm{S} \mid \mathrm{O}$ & $\mathrm{N}$ & $D$ & & $\mathrm{~F}$ & $M$ & & M & J & $\mathrm{J}$ & $\mathrm{A}$ & $\mathrm{s} \mid \mathrm{c}$ & & & & $\mathrm{F}$ & M & $\mathrm{A}$ & & $\mathrm{J}$ & $\mathrm{J}$ & $A$ \\
\hline Task 1. Project management & $9 / 14 / 06$ & $9 / 30 / 09$ & & & & & & & & & & & & & & & & & & & & & & & & & & \\
\hline Task 2. Biostimulation design & & & & & & & & & & & & & & & & & & & & & & & & & & & & \\
\hline 2.1. Data review and CM development & 9/14/06 & $1 / 31 / 07$ & & $\mathrm{nple}$ & ted & & & & & & & & & & & & & & & & & & & & & & & \\
\hline 2.2. Initial design analysis & 9/14/06 & $1 / 31 / 07$ & & $\mathrm{nple}$ & ted & & & & & & & & & & & & & & & & & & & & & & & \\
\hline Task 3. Pilot-scale injection tests & & & & & & & & & & & & & & & & & & & & & & & & & & & & \\
\hline 3.1. Treatability Test Plan & 11/1/06 & $6 / 15 / 07$ & & & & & & & & & & & & & & & & & & & & & & & & & & \\
\hline 3.2 Well installation & $5 / 1 / 07$ & $6 / 30 / 07$ & & & & & & & & & & & & & & & & & & & & & & & & & & \\
\hline 3.3 Bench-scale studies & & & & & & & & & & & & & & & & & & & & & & & & & & & & \\
\hline 3.3.1 Substrate testing & $5 / 15 / 07$ & $8 / 30 / 07$ & & & & & & & & & & & & & & & & & & & & & & & & & & \\
\hline 3.3.2. Emulsion transport studies & $5 / 15 / 07$ & $1 / 30 / 08$ & & & & & & & & & & & & & & & & & & & & & & & & & & \\
\hline 3.4 Injection design analysis & & & & & & & & & & & & & & & & & & & & & & & & & & & & \\
\hline Molasses test & $7 / 15 / 07$ & $8 / 30 / 07$ & & & & & & & & & & & & & & & & & & & & & 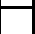 & & & & & \\
\hline Emulsified oil test & $1 / 30 / 08$ & $6 / 30 / 08$ & & & & & & & & & & & & & & & & & & & & & & & & & & \\
\hline 3.5. Field test injections & & & & & & & & & & & & & & & & & & & & & & & & & & & & \\
\hline Molasses test cell & & & & & & & & & & & & & & & & & & & & & & & & & & & & \\
\hline field equipment setup & $7 / 15 / 07$ & 9/15/07 & & & & & & & & & & & & & & & & & & & & & & & & & & \\
\hline injection/process monitoring & $9 / 1 / 07$ & $11 / 30 / 07$ & & & & & & & & & & & & & & & & & & & & & & & & & & \\
\hline Emulsified oil test cell & & & & & & & & & & & & & & & & & & & & & & & & & & & & \\
\hline field equipment setup & $6 / 30 / 08$ & $8 / 30 / 08$ & & & & & & & & & & & & & & & & & & & & & & & & & & \\
\hline injection/process monitoring & $8 / 1 / 08$ & $10 / 30 / 08$ & & & & & & & & & & & & & & & & & & & & & & & & & & \\
\hline geophysical characterization & $7 / 30 / 08$ & $10 / 30 / 08$ & & & & & & & & & & & & & & & & & & & & & & & & & & \\
\hline Task 4. Performance monitoring & & & & & & & & & & & & & & & & & & & & & & & & & & & & \\
\hline Molasses test cell & $12 / 15 / 07$ & 9/30/09 & & & & & & & & & & & & & & & & & & & & & & & & & & \\
\hline Emulsified oil test cell & $11 / 1 / 08$ & $9 / 30 / 09$ & & & & & & & & & & & & & & & & & & & & & & & & & & \\
\hline Task 5. Data analysis and reporting & $12 / 15 / 07$ & $9 / 30 / 09$ & & & & & & & & & & & & & & & & & & & & & 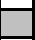 & & & & & \\
\hline Milestone: Final Report & & 9/30/09 & & & & & & & & & & & & & & & & & & & & & 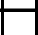 & & & & & \\
\hline
\end{tabular}

Figure 14.1. Schedule of Field Test Activities 


\subsection{References}

16 USC 688 et seq. 1992. Bald and Golden Eagle Protection Act. Public Law 87-884, as amended, 76 Stat. 1246.

16 USC 1531 et seq. 1973. Endangered Species Act. Public Laws 93-205 through 100-707, as amended, 87 Stat. 884.

16 USC 470 et seq. 1966. National Historic Preservation Act. Public Law 89-665, as amended.

16 USC 703-712. 1918. Migratory Bird Treaty Act. 1918. Chapter 128, as amended, 40 Stat. 755.

33 USC 1251 et seq. 1977. Clean Water Act of 1977. Public Law 107-303, as amended.

42 USC 6901 et seq. 1976. Resource Conservation and Recovery Act. Public Law 94-580, as amended, 90 Stat. 2795.

42 USC 9601 et seq. 1980. Comprehensive Environmental Response, Compensation, and Liability Act. Public Law 96-510, as amended, 94 Stat. 2767.

10 CFR 830, Subpart A. “Quality Assurance Requirements.” Code of Federal Regulations, U.S. Department of Energy.

40 CFR 122. "EPA Administered Permit Programs: The National Pollutant Discharge Elimination System.” Code of Federal Regulations, U.S. Environmental Protection Agency.

40 CFR 131, “Ambient Water Quality Criteria for Protection of Aquatic Life.” Code of Federal Regulations, U.S. Environmental Protection Agency.

40 CFR 131.36. "Water Quality Standards; Toxics Criteria for those States Not Complying with Clean Water Act Section 303(c)(2)(B)." Code of Federal Regulations, U.S. Environmental Protection Agency.

40 CFR 144, Subpart B. "Underground Injection Control Program.” Code of Federal Regulations, U.S. Environmental Protection Agency.

40 CFR 300.400. "National Oil and Hazardous Substances Pollution Contingency Plan; General." Code of Federal Regulations, U.S. Environmental Protection Agency.

Alam M, A Hossain, D Yonge, B Peyton, and J Petersen. 2006. "Bioreduction of Hexavalent Chromium in Flow-Through Quartz Sand Columns." J. Environ. Engineering 132(3):358-366.

Borden RC and BX Rodriguez. 2006. "Evaluation of Slow Release Substrates for Anaerobic Bioremediation.” Bioremediation J. 10(1-2):59-69.

Brown DJ. 1963. Status of the Groundwater Beneath Hanford Reactor Areas: January 1962 to January 1963. HW-77170, Hanford Atomic Products Operation, General Electric Company, Richland, Washington. 
Coulibaly KM and RC Borden. 2004. "Impact of Edible Oil Injection on the Permeability of Aquifer Sands.” J. Contam. Hydrol. 71:219-237.

DOE. 1993. 100 Area Feasibility Study, Phases 1 and 2. DOE/RL-92-11, Rev. 0, U.S. Department of Energy, Richland Operations Office, Richland, Washington.

DOE. 1994. Limited Field Investigation Report for the 100-HR-3 Operable Unit. DOE/RL-93-43, Rev. 0, September 1994. Prepared by IT Corporation for Westinghouse Hanford Company, U.S. Department of Energy, Richland, Washington.

DOE. 1995. 100-HR-3 Operable Unit Focused Feasibility Study. DOE/RL-94-67, Rev. 0, U.S. Department of Energy, Richland Operations Office, Richland, Washington.

DOE. 2006. Calendar Year 2005 Annual Summary Report for the 100-HR-3, 100-KR-4, and 100-NR-2 Operable Unit Pump-and-Treat Operations. DOE/RL-2006-08, U.S. Department of Energy, Richland, Washington.

DOE Order 451.1B. "National Environmental Policy Act Compliance Program.” U.S. Department of Energy, Washington, D.C.

DOE Order 414.1C. “Quality Assurance.” U.S. Department of Energy, Washington, D.C.

Ecology, EPA, and DOE. 1990, as amended. Hanford Federal Facility Agreement and Consent Order, 2 vols. Washington State Department of Ecology, U.S. Environmental Protection Agency, and U.S. Department of Energy, Olympia, Washington.

EPA. 1992. Guide for Conducting Treatability Studies Under CERCLA. Final Rule, EPA/540/R-92/071a, U.S. Environmental Protection Agency, Washington, D.C.

EPA. 1996. Declaration of the Record of Decision for the 100-HR-3 and 100-KR-4 Operable Units. EPA/ROD/R10-96/134, U. S. Environmental Protection Agency, Washington, D.C.

EPA. 1999. Interim Record of Decision Amendment at the 100-HR-3 Operable Unit.

U.S. Environmental Protection Agency, Washington, D. C.

EPA Method 6010B. Inductively Coupled Plasma-Atomic Emission Spectrometry. U.S. Environmental Protection Agency, Washington, D.C.

EPA Method 6020. Inductively Coupled Plasma-Mass Spectrometry. U.S. Environmental Protection Agency, Washington, D.C.

Gemoets J, C Gielen, N Hermans, Y Vermoortel, and M Carpels. 2003. "Evaluation of the Potential for Natural Attenuation and In Situ Bioprecipiation of Chromium in Groundwater." Paper L-07 in Proceedings of the Seventh International In Situ and On-Site Bioremedaitoin Symposium, Orlando, Florida.

Hanford Reach Study Act, H.R. 3614, November 4, 1988. Public Law 100-605, as amended by Public Law 404-133. Accessed October 17, 2007, at http://206.61.210.104/pl/iap/html/body_apx-a.htm. 
HAPO. 1953. Process Specifications, Reactor Cooling Water Treatment. HW-28505, Hanford Atomic Products Operation, General Electric Company, Richland, Washington.

Hartman MJ. 1999. Hanford Site Groundwater: Settings, Sources, and Methods. PNNL-13080, Pacific Northwest National Laboratory, Richland, Washington.

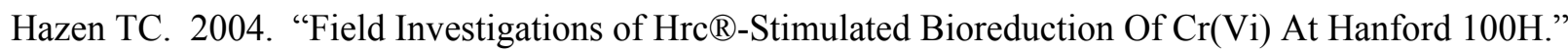
In Fourth International Conference on Remediation of Chlorinated and Recalcitrant Compounds, Monterey, California, May 2004. Accessed June 4, 2007, at http://esd.lbl.gov/ERT/hanford100h/results.html.

Hooker BS, RS Skeen, MJ Truex, CD Johnson, BM Peyton, and DB Anderson. 1998. "In Situ Bioremediation of Carbon Tetrachloride: Field Test Results." Bioremediation J. 3:181-193.

Hunter WJ. 2001. "Use of Vegetable Oil in a Pilotscale Denitrifying Barrier." J. Contam. Hydrol. 53:119-131.

Hunter WJ. 2005. "Injection of Innocuous Oil to Create Reactive Barriers for Bioremediation: Laboratory Studies." J. Contam. Hydrol. 80:31-48.

Lindsey KA and GK Jaeger. 1993. Geologic Setting of the 100-HR-3 Operable Unit, Hanford Site, South-Central Washington. WHC-SD-EN-TI-132, Rev. 0, Westinghouse Hanford Company, Richland, Washington.

McCarty PL. 1975. “Stoichiometry of Biological Reactions.” Prog. In Water. Technol. 7(1):157-172.

Parsons Corporation (Parsons). 2004. Principles and Practices of Enhanced Anaerobic Bioremediation of Chlorinated Solvents. Parsons Corporation, Charleston, West Virginia. Accessed June 4, 2007, at http://costperformance.org/remediation/pdf/principles_and_practices_bioremediation.pdf.

Peterson RE, RF Raidl, and CW Denslow. 1996. Conceptual Site Models for Groundwater Contamination at 100-BC-5, 100-KR-4, 100-HR-3, and 100-FR-3 Operable Units, Hanford Site.

BHI-00917, Rev. 0, September 1996. Prepared by CH2M HILL Hanford, Inc. for Bechtel Hanford, Inc., Richland, Washington.

PNNL. 2007. The Columbia River Protection Supplemental Technologies Quality Assurance Project Plan. PNNL-16340, Pacific Northwest National Laboratory, Richland, Washington.

Sleep BE, AJ Brown, and B Sherwood Lollar. 2005. "Long-Term Tetrachloroethene Degradation Sustained by Endogenous Cell Decay.” J. Environ. Eng. Sci. 4:11-17.

Soo H and CJ Radke. 1986. "A Filtration Model for the Flow of Dilute, Stable Emulsions in Porous Media - I. Theory." Chemical Eng. Sci. 41(2):263-272.

Soo H, MC Williams, and CJ Radke. 1986. "A Filtration Model for the Flow of Dilute, Stable Emulsions in Porous Media - II. Parameter Evaluation and Estimation." Chemical Eng. Sci. 41(2):273-281. 
Szecsody JE, VR Vermeul, JS Fruchter, MD Williams, BJ Devary, JL Phillips, ML Rockhold, and Y Liu. 2005. Effect of Geochemical and Physical Heterogeneity on the Hanford 100D Area In Situ Redox Manipulation Barrier Longevity. PNNL-15499, Pacific Northwest National Laboratory, Richland, Washington.

WAC 173-160. "Minimum Standards for Construction and Maintenance of Wells." Washington Administrative Code, Olympia, Washington.

WAC 173-162. "Regulation and Licensing Of Well Contractors and Operators." Washington Administrative Code, Olympia, Washington.

WAC 173-200. "Water Quality Standards for Ground Waters of the State of Washington." Washington Administrative Code, Olympia, Washington.

WAC 173-218. "Underground Injection Control Program.” Washington Administrative Code, Olympia, Washington.

WAC 173-303. "Dangerous Waste Regulations.” Washington Administrative Code, Olympia, Washington.

WAC 173-304. "Minimum Functional Standards for Solid Waste Handling." Washington Administrative Code, Olympia, Washington.

WAC 232-12-292. "Bald Eagle Protection Rules.” Washington Administrative Code, Olympia, Washington.

Williams MD, VR Vermeul, JE Szecsody, and JS Fruchter. 2000. 100-D Area In Situ Redox Treatability Test for Chromate-Contaminated Water. PNNL-13349, Pacific Northwest National Laboratory, Richland, Washington.

Yang Y and PL McCarty. 2000. "Biomass, Oleate, and Other Possible Substrates for Chloroethene Reductive Dehalogenation.” Bioremediation J. 4(2):125-133. 


\title{
Appendix A
}

\author{
Test Plan
}

Stoichiometry and Kinetics of Nitrate, Oxygen, and Chromate Reduction in 100-D Ringold Sediments with Immiscible and Soluble Substrates 


\section{Contents}

A.1 Experimental Goals and Objectives ............................................................................... A.1

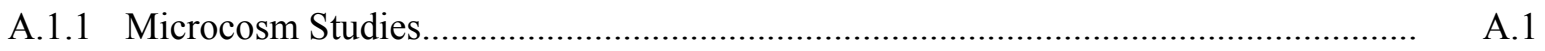

A.1.2 Soil Column Studies ................................................................................... A.1

A.2 Experimental Procedures …....................................................................................... A.2

A.2.1 Microcosm Studies...................................................................................... A.2

A.2.2 Soil Column Studies ........................................................................................... A.6

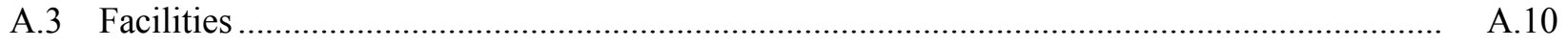

A.4 Hazards Assessment ................................................................................................. A.10

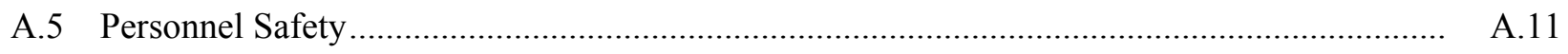

A.5.1 Personnel Protective Equipment ............................................................................. A.11

A.5.2 Material Safety Data Sheets ........................................................................... A.11

A.5.3 Respiratory Protection Requirements ............................................................... A.11

A.5.4 Medical Requirements ...................................................................................... A.11

A.5.5 Confined Space ...................................................................................... A.11

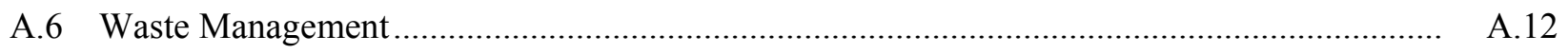

A.7 Associated Procedures and Safety Limits …........................................................................ A.12

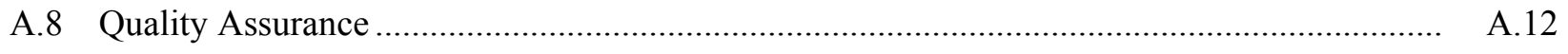

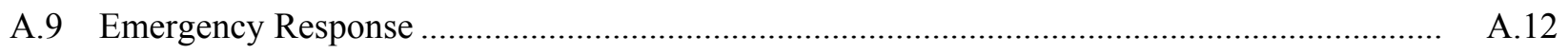

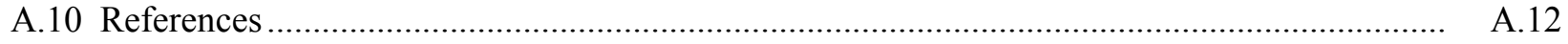

\section{Tables}

A.1 Experimental Conditions for Microcosms ....................................................................... A.3

A.2 Sampling and Analysis Constituents and Schedule ........................................................ A.5

A.3 Experimental Conditions for Soil ................................................................................... A.7

A.4 Sampling and Analysis Constituents and Schedule ........................................................ A.9 


\section{Appendix A}

\section{A.1 Experimental Goals and Objectives}

The following laboratory tests are being conducted to support design of a field test for biostimulation as a means to create a reducing barrier for nitrate, chromate, and oxygen in the 100-D Area of the Hanford Site. This test plan outlines experimental procedures using microcosm studies to test a soluble substrate (molasses) and subsequent endogenous microbial decay as a long-term substrate for the reducing barrier. The test plan also outlines experimental procedures using soil columns to test an immiscible substrate (vegetable oil or polylactate) as a long-term substrate for the reducing barrier. While experimental details have been provided in this test plan, some adjustments to the experimental matrix may be implemented based on the results of initial preliminary experiments that will be conducted once site-specific sediments and groundwater are received.

\section{A.1.1 Microcosm Studies}

The following questions will be investigated for use of molasses and subsequent endogenous microbial decay as a long-term substrate for the reducing barrier:

1. What is the yield of biomass from molasses alone or from molasses and nitrate or from molasses and chromate or from molasses, nitrate, and chromate?

2. What is the rate of molasses consumption, denitrification, and chromate reduction when molasses is present?

3. What is the rate of denitrification and chromate reduction during endogenous microbial decay?

4. What is the rate of endogenous microbial decay?

5. Is the rate of endogenous microbial decay and coincident denitrification, or chromate reduction dependent on whether nitrate or chromate are present during biomass growth?

6. What is the rate of molasses consumption under aerobic conditions?

\section{A.1.2 Soil Column Studies}

The following questions will be investigated for use of vegetable oil or polylactate as a long-term substrate for the reducing barrier:

1. What is the rate of denitrification and chromate reduction stimulated by vegetable oil or polylactate?

2. What is the rate of oil or polylactate loss during active denitrification, chromate reduction, oxygen reduction, and fermentation processes? 
3. What is the aqueous-phase concentration of dissolved oil, polylactate, or fermentation products during oxygen reduction and fermentation processes?

4. What is the aqueous-phase concentration of dissolved oil or polylactate without oxygen reduction or fermentation processes?

\section{A.2 Experimental Procedures}

The following sections describe the procedures that will be followed during microcosm and soil column studies. These laboratory tests will be performed at Pacific Northwest National Laboratory.

\section{A.2.1 Microcosm Studies}

Results of microcosm studies will be used as input to the final field test design. The tests are designed to investigate the experimental goals and objectives (Section A.1).

\section{A.2.1.1 Experimental Matrix}

Table A.1 provides a detailed list of the experimental conditions that will be evaluated in this effort. Some details of this experimental matrix may be modified (e.g., amendment concentrations) depending on the results of initial preliminary experiments. Treatments 1 and 2 will have 9 replicate bottles. Treatment 3 will have 6 replicate bottles. Other treatments will be conducted in triplicate. Killed controls and no substrate controls will be included as noted in Table A.1. This experimental matrix results in a total of 39 individual microcosm bottles.

Prior to conducting this matrix of treatments, a preliminary test will be conducted using eight microcosm bottles. The microcosms will be configured the same as shown for treatment 1 in Table A.1 except the treatments will use varying amounts of molasses, $50 \mathrm{~g}$ of composite sediment and $90 \mathrm{~mL}$ of groundwater in 160-mL serum bottles, and a bicarbonate buffer. The preliminary treatments will be incubated and monitored for disappearance of molasses, production and disappearance of fermentation products, and $\mathrm{pH}$. The preliminary treatments will be terminated when the molasses and primary fermentation products are depleted. The purpose of this preliminary test is to determine appropriate buffering for the primary test matrix, test analytical methods and potential interferences, and to evaluate the progression of molasses fermentation as a function of initial molasses concentration (e.g., potential for souring of the reaction). Treatments included in preliminary test include 1) molasses at $50 \mathrm{~g} / \mathrm{L}$ and bicarbonate buffering at $10,30,100$, and $300 \mathrm{mM}$ and 2) a bicarbonate concentration of $10 \mathrm{mM}$ and molasses concentrations of 25, 12, 6, and $1 \mathrm{~g} / \mathrm{L}$. Similar tests with PIPES buffer will be implemented if significant interferences are observed with the bicarbonate buffer.

\section{A.2.1.2 Media Preparation Methods}

Filter sterile stock solutions for molasses, nitrate, chromate, ammonium chloride, and potassium phosphate will be prepared and stored at $4^{\circ} \mathrm{C}$. 
Table A.1. Experimental Conditions for Microcosms

\begin{tabular}{|c|c|c|c|c|c|c|}
\hline Treatment & Amendments $^{(a)}$ & $\begin{array}{l}\text { Auto- } \\
\text { claved? }\end{array}$ & $\begin{array}{l}\text { Temper- } \\
\text { ature }\end{array}$ & $\begin{array}{l}\text { Head- } \\
\text { space }\end{array}$ & Sediment & Groundwater \\
\hline 1 & $\begin{array}{l}50 \mathrm{~g} / \mathrm{L} \text { molasses } \\
(10 \mathrm{~g} / \mathrm{bottle}) . \text { When } \\
\text { molasses is gone, spike with } \\
60 \mathrm{mg} / \mathrm{L} \text { nitrate and } 1 \mathrm{mg} / \mathrm{L} \\
\text { chromate. }\end{array}$ & No & $18^{\circ} \mathrm{C}$ & $\begin{array}{l}\mathrm{N}_{2} / \mathrm{CO}_{2} \\
\text { gas } \\
\text { purged }\end{array}$ & $\begin{array}{l}100 \mathrm{~g} \\
\text { composite } \\
\text { from } 100-\mathrm{D} \\
<2 \mathrm{~mm}\end{array}$ & $\begin{array}{l}200 \mathrm{~mL} \text {, uncontam- } \\
\text { inated from } 100-\mathrm{D} \text {, } \\
\text { equilibrated with } \\
\text { air, filter sterilized }\end{array}$ \\
\hline 2 & $\begin{array}{l}1 \mathrm{~g} / \mathrm{L} \text { molasses } \\
(0.2 \mathrm{~g} / \text { bottle }) . \text { When } \\
\text { molasses is gone, spike with } \\
60 \mathrm{mg} / \mathrm{L} \text { nitrate and } 1 \mathrm{mg} / \mathrm{L} \\
\text { chromate. }\end{array}$ & No & $18^{\circ} \mathrm{C}$ & $\begin{array}{l}\mathrm{N}_{2} / \mathrm{CO}_{2} \\
\text { gas } \\
\text { purged }\end{array}$ & $\begin{array}{l}100 \mathrm{~g} \\
\text { composite } \\
\text { from } 100-\mathrm{D} \\
<2 \mathrm{~mm}\end{array}$ & $\begin{array}{l}200 \mathrm{~mL} \text {, uncontam- } \\
\text { inated from } 100-\mathrm{D} \text {, } \\
\text { equilibrated with } \\
\text { air, filter sterilized }\end{array}$ \\
\hline 3 & $\begin{array}{l}50 \mathrm{~g} / \mathrm{L} \text { molasses } \\
(10 \mathrm{~g} / \mathrm{bottle}), 60 \mathrm{mg} / \mathrm{L} \\
\text { nitrate and } 1 \mathrm{mg} / \mathrm{L} \\
\text { chromate. When molasses, } \\
\text { nitrate, and chromate are } \\
\text { gone, spike with } 60 \mathrm{mg} / \mathrm{L} \\
\text { nitrate and } 1 \mathrm{mg} / \mathrm{L} \\
\text { chromate. }\end{array}$ & No & $18^{\circ} \mathrm{C}$ & $\begin{array}{l}\mathrm{N}_{2} / \mathrm{CO}_{2} \\
\text { gas } \\
\text { purged }\end{array}$ & $\begin{array}{l}100 \mathrm{~g} \\
\text { composite } \\
\text { from } 100-\mathrm{D} \\
<2 \mathrm{~mm}\end{array}$ & $\begin{array}{l}200 \mathrm{~mL} \text {, uncontam- } \\
\text { inated from } 100-\mathrm{D} \text {, } \\
\text { equilibrated with } \\
\text { air, filter sterilized }\end{array}$ \\
\hline 4 & $\begin{array}{l}50 \mathrm{~g} / \mathrm{L} \text { molasses } \\
(4.5 \mathrm{~g} / \text { bottle }), 60 \mathrm{mg} / \mathrm{L} \\
\text { nitrate. }\end{array}$ & No & $18^{\circ} \mathrm{C}$ & $\begin{array}{l}\mathrm{N}_{2} / \mathrm{CO}_{2} \\
\text { gas } \\
\text { purged }\end{array}$ & $\begin{array}{l}50 \mathrm{~g}, \\
\text { composite } \\
\text { from } 100-\mathrm{D}, \\
<2 \mathrm{~mm} \\
\end{array}$ & $\begin{array}{l}90 \mathrm{~mL} \text {, uncontam- } \\
\text { inated from } 100-\mathrm{D} \text {, } \\
\text { equilibrated with } \\
\text { air, filter sterilized }\end{array}$ \\
\hline 5 & $\begin{array}{l}50 \mathrm{~g} / \mathrm{L} \text { molasses } \\
(4.5 \mathrm{~g} / \mathrm{bottle}), 1 \mathrm{mg} / \mathrm{L} \\
\text { chromate. }\end{array}$ & No & $18^{\circ} \mathrm{C}$ & $\begin{array}{l}\mathrm{N}_{2} / \mathrm{CO}_{2} \\
\text { gas } \\
\text { purged }\end{array}$ & $\begin{array}{l}50 \mathrm{~g}, \\
\text { composite } \\
\text { from } 100-\mathrm{D}, \\
<2 \mathrm{~mm} \\
\end{array}$ & $\begin{array}{l}90 \mathrm{~mL} \text {, uncontam- } \\
\text { inated from } 100-\mathrm{D} \text {, } \\
\text { equilibrated with } \\
\text { air, filter sterilized }\end{array}$ \\
\hline $\begin{array}{l}6 \\
\text { (control) }\end{array}$ & $\begin{array}{l}60 \mathrm{mg} / \mathrm{L} \text { nitrate and } 1 \mathrm{mg} / \mathrm{L} \\
\text { chromate. }\end{array}$ & No & $18^{\circ} \mathrm{C}$ & $\begin{array}{l}\mathrm{N}_{2} / \mathrm{CO}_{2} \\
\text { gas } \\
\text { purged }\end{array}$ & $\begin{array}{l}50 \mathrm{~g}, \\
\text { composite } \\
\text { from } 100-\mathrm{D} \\
<2 \mathrm{~mm} \\
\end{array}$ & $\begin{array}{l}90 \mathrm{~mL} \text {, uncontam- } \\
\text { inated from } 100-\mathrm{D} \text {, } \\
\text { equilibrated with } \\
\text { air, filter sterilized }\end{array}$ \\
\hline $\begin{array}{l}7 \\
\text { (control) }\end{array}$ & $\begin{array}{l}50 \mathrm{~g} / \mathrm{L} \text { molasses } \\
(4.5 \mathrm{~g} / \mathrm{bottle}), 60 \mathrm{mg} / \mathrm{L} \\
\text { nitrate and } 1 \mathrm{mg} / \mathrm{L} \\
\text { chromate. }\end{array}$ & Yes & $18^{\circ} \mathrm{C}$ & $\begin{array}{l}\mathrm{N}_{2} / \mathrm{CO}_{2} \\
\text { gas } \\
\text { purged }\end{array}$ & $\begin{array}{l}50 \mathrm{~g}, \\
\text { composite } \\
\text { from } 100-\mathrm{D} \\
<2 \mathrm{~mm}\end{array}$ & $\begin{array}{l}90 \mathrm{~mL} \text {, uncontam- } \\
\text { inated from } 100-\mathrm{D} \text {, } \\
\text { equilibrated with } \\
\text { air, filter sterilized }\end{array}$ \\
\hline 8 & $\begin{array}{l}50 \mathrm{~g} / \mathrm{L} \text { molasses } \\
(4.5 \mathrm{~g} / \text { bottle })\end{array}$ & No & $18^{\circ} \mathrm{C}$ & $\begin{array}{l}100 \% \\
\mathrm{O}_{2}\end{array}$ & $\begin{array}{l}50 \mathrm{~g}, \\
\text { composite } \\
\text { from } 100-\mathrm{D}, \\
<2 \mathrm{~mm}\end{array}$ & $\begin{array}{l}90 \mathrm{~mL}, \text { uncontam- } \\
\text { inated from 100-D, } \\
\text { equilibrated with } \\
\text { air, filter sterilized }\end{array}$ \\
\hline \multicolumn{7}{|c|}{$\begin{array}{l}\text { (a) All treatments will contain } 100-\mathrm{mg} / \mathrm{L} \text { ammonium chloride and } 10-\mathrm{mg} / \mathrm{L} \text { potassium phosphate in the initial } \\
\text { amendment spike. }\end{array}$} \\
\hline
\end{tabular}




\section{A.2.1.3 Sediment and Groundwater Sampling Methods}

Filter sterilized groundwater will be collected in pre-sterilized polypropylene bottles. Split-spoon sediment samples will be collected in pre-sterilized Lexan liners. The liners will be capped in the field, put in a cooler with ice, and transferred to the laboratory. Sediment and groundwater samples will be stored at $4^{\circ} \mathrm{C}$ until used in microcosm tests. The small size fraction of the sediment samples will be composited under aseptic conditions prior to use in microcosm tests.

\section{A.2.1.4 Test Methods}

All microcosm bottles will be prepared in an aseptic atmosphere (e.g., laminar flow hood). Approximately $100 \mathrm{~g}$ of sediment will be transferred into $500-\mathrm{mL}$ pre-sterilized serum bottles for treatments 1 through 3. Approximately $50 \mathrm{~g}$ of sediment will be transferred into $250-\mathrm{mL}$ pre-sterilized serum bottles for treatments 4 through 7 . The amount of sediment added to each bottle will be quantified by weighing the bottle both before and after sediment addition. Next, $200 \mathrm{~mL}$ (treatments 1 through 3) or $90 \mathrm{~mL}$ (treatments 4 through 7) of filter sterilized groundwater corresponding to the same geologic zone as the sediment sample will be added to each bottle and the bottles will be sealed with butyl rubber septa and aluminum crimp caps. The bottles except for treatment 8 will then be transferred to a gassing station where the headspace and aqueous phase will be purged with anoxic gas containing $20 \% \mathrm{CO}_{2}$ and $80 \%$ nitrogen. For treatment 8 , the headspace will be purged with pure oxygen gas for 1 minute. Killed controls will be constructed using the same procedures as for the active microcosms except that after bottles are constructed, they will be autoclaved.

The appropriate amendments according to Table A.1 will be added to each bottle as a sterile water stock solution using a sterile syringe. After amendments are added, the headspace pressure will be relieved using a sterile needle. The serum bottles will then be mixed and the bottles sampled as described in the next section to determine the initial concentration of all constituents. The bottles will then be quiescently incubated in the dark at $18^{\circ} \mathrm{C}$ and periodically sampled as described in the next section. This temperature was selected as representative of that for the 100-D Area aquifer.

\section{A.2.1.5 Sampling and Analysis}

The aqueous phase in microcosms will be sampled for the constituents per the schedules outlined in Table A.2. The bottle will be swirled to mix the contents then allowed to settle 2 to 4 hours before sampling. The initial (0) sample will be collected on the day that the microcosm is prepared and upon addition of spikes. Headspace pressure in each bottle will be monitored and addressed per the 331 Building anaerobic experiment Standard Operating Procedures. It is expected that nitrate/nitrite and chromate monitoring after molasses is depleted in treatments 1 and 2 will be conducted for at least 100 days. Depending on initial results, treatment 3 may also be conducted over the same time interval as treatments 1 and 2. If the initial rates of nitrate and chromate reduction after molasses is depleted are comparable to treatments 1 and 2, then treatment 3 will be terminated 30 days after molasses has been depleted. Treatments 4,5 , and 8 will be terminated when molasses is depleted.

Samples for molasses and fermentation products (e.g., lactate, propionate, acetate, butyrate, and ethanol) will be collected by removing $1 \mathrm{~mL}$ of water with a $2.5-\mathrm{mL}$ syringe, filtering with a sterile $0.2 \mu \mathrm{m}$ filter, and dispensing into a vial containing preservative. Samples will be analyzed by high

pressure liquid chromatography. Samples for nitrate, nitrite, and sulfur-based anions will be collected by removing $1 \mathrm{~mL}$ of water with a $2.5-\mathrm{mL}$ syringe and dispensing into a vial containing preservative. 
Table A.2. Sampling and Analysis Constituents and Schedule

\begin{tabular}{|c|c|c|c|}
\hline Treatment & Constituent & Schedule $^{(a)}$ & Destructive Sampling for Biomass \\
\hline \multirow[t]{4}{*}{1} & Molasses $^{(\mathrm{b})}$ & 2 per week until gone & NA \\
\hline & $\begin{array}{l}\text { Nitrate, nitrite and } \\
\text { other major anions }\end{array}$ & After spike, 2 per week ${ }^{(\mathrm{c})}$ & NA \\
\hline & Chromate & After spike, 2 per week ${ }^{(\mathrm{c})}$ & NA \\
\hline & Biomass & & $\begin{array}{l}3 \text { bottles sampled after molasses is gone, } \\
3 \text { bottles sampled after first spike is } \\
\text { depleted, } 3 \text { bottles at end of test }\end{array}$ \\
\hline \multirow[t]{4}{*}{2} & molasses $^{(\mathrm{b})}$ & 2 per week until gone & NA \\
\hline & $\begin{array}{l}\text { Nitrate, nitrite and } \\
\text { other major anions }\end{array}$ & After spike, 2 per week ${ }^{(\mathrm{c})}$ & NA \\
\hline & Chromate & After spike, 2 per week ${ }^{(\mathrm{c})}$ & NA \\
\hline & Biomass & & $\begin{array}{l}3 \text { bottles sampled after molasses is gone, } \\
3 \text { bottles sampled after first spike is } \\
\text { depleted, } 3 \text { bottles at end of test }\end{array}$ \\
\hline \multirow[t]{4}{*}{3} & Molasses $^{(\mathrm{b})}$ & 2 per week until gone & NA \\
\hline & $\begin{array}{l}\text { Nitrate, nitrite and } \\
\text { other major anions }\end{array}$ & $\begin{array}{l}1 \text { per week initially and then } \\
2 \text { per week }^{\left({ }^{()}\right)} \text {after spike }\end{array}$ & NA \\
\hline & Chromate & $\begin{array}{l}1 \text { per week initially and then } \\
2 \text { per week }{ }^{(c)} \text { after spike }\end{array}$ & NA \\
\hline & Biomass & & $\begin{array}{l}3 \text { bottles sampled after molasses is gone, } \\
3 \text { bottles at end of test }\end{array}$ \\
\hline \multirow[t]{3}{*}{4} & Molasses $^{(b)}$ & 2 per week until gone & NA \\
\hline & $\begin{array}{l}\text { Nitrate, nitrite and } \\
\text { other major anions }\end{array}$ & 1 per week $^{(\mathrm{c})}$ & NA \\
\hline & Biomass & & $\begin{array}{l}\text { All } 3 \text { bottles sampled after molasses is gone } \\
\text { (end of test) }\end{array}$ \\
\hline \multirow[t]{3}{*}{5} & Molasses $^{(b)}$ & 2 per week until gone & NA \\
\hline & Chromate & 1 per week $^{(\mathrm{c})}$ & NA \\
\hline & Biomass & & $\begin{array}{l}\text { All } 3 \text { bottles sampled after molasses is gone } \\
\text { (end of test) }\end{array}$ \\
\hline \multirow[t]{2}{*}{6} & $\begin{array}{l}\text { Nitrate, nitrite and } \\
\text { other major anions }\end{array}$ & $\begin{array}{l}2 \text { per week, }{ }^{(\mathrm{c})} \text { for } 2 \text { weeks } \\
\text { and then } 1 \text { per month for } \\
\text { same duration as treatment } 1\end{array}$ & NA \\
\hline & Chromate & $\begin{array}{l}2 \text { per week, }{ }^{(\mathrm{c})} \text { for } 2 \text { weeks } \\
\text { and then } 1 \text { per month for } \\
\text { same duration as treatment } 1\end{array}$ & NA \\
\hline
\end{tabular}


Table A.2. (contd)

\begin{tabular}{|c|c|c|c|}
\hline Treatment & Constituent & Schedule $^{(a)}$ & Destructive Sampling for Biomass \\
\hline \multirow[t]{3}{*}{7} & Molasses $^{(b)}$ & $\begin{array}{l}2 \text { per week, }{ }^{(\mathrm{c})} \text { for } 2 \text { weeks } \\
\text { and then } 1 \text { per month for } \\
\text { same duration as treatment } 1\end{array}$ & NA \\
\hline & $\begin{array}{l}\text { Nitrate, nitrite and } \\
\text { other major anions }\end{array}$ & $\begin{array}{l}2 \text { per week, }{ }^{(\mathrm{c})} \text { for } 2 \text { weeks } \\
\text { and then } 1 \text { per month for } \\
\text { same duration as treatment } 1\end{array}$ & NA \\
\hline & Chromate & $\begin{array}{l}2 \text { per week }{ }^{(\mathrm{c})} \text { for } 2 \text { weeks } \\
\text { and then } 1 \text { per month for } \\
\text { same duration as treatment } 1\end{array}$ & NA \\
\hline 8 & Molasses $^{(\mathrm{b})}$ & 1 per day for 1 week & NA \\
\hline \multicolumn{4}{|c|}{$\begin{array}{l}\text { (a) The schedule is listed in days from initiation of test or days from the noted start point. } \\
\text { (b) Fermentation product including lactate, propionate, acetate, butyrate, and ethanol and pH will also be monitored along } \\
\text { with molasses (sucrose). } \\
\text { (c) Sampling interval may be changed depending on initial rate of change. } \\
\text { NA = Not applicable. }\end{array}$} \\
\hline
\end{tabular}

Samples will be analyzed by ion chromatography. Samples for chromate will be collected by removing $1 \mathrm{~mL}$ of water with a $2.5-\mathrm{mL}$ syringe and dispensing into a vial containing preservative. Samples will be analyzed with a test kit (HACH model 5870017). The $\mathrm{pH}$ will be determined in 1-mL samples collected by removing $1 \mathrm{~mL}$ of water with a $2.5-\mathrm{mL}$ syringe using a $\mathrm{pH}$ probe. All stock solutions will also be measured using the methods described above.

Destructive sampling and testing for biomass will be conducted by adenosine triphosphate (ATP) analysis using methods based on results of preliminary experiments.

Data will be maintained both in an approved Laboratory Record Book and in Microsoft Excel.

\section{A.2.2 Soil Column Studies}

Results of soil column studies will be used as input to the final field test design. The tests are designed to investigate the experimental goals and objectives (Section A.1).

\section{A.2.2.1 Experimental Matrix}

Table A.3 provides a detailed list of the experimental conditions that will be evaluated in this effort for the vegetable oil substrate. The same experimental matrix will be implemented for the polylactate substrate except that the no-substrate controls will not be duplicated. Some details of this experimental matrix may be modified (e.g., amendment concentrations) depending on the results of initial preliminary experiments. Treatments 1 through 3 will have 3 replicate columns. Control treatments 4 and 5 will have one column each. Treatments 6 and 7 will have 2 replicate columns. This experimental matrix results in a total of 15 individual soil columns. 


\section{A.2.2.2 Media Preparation Methods}

Filter sterile stock solutions for nitrate and chromate will be prepared and stored at $4{ }^{\circ} \mathrm{C}$. The oil/emulsifier material and polylactate used in the soil column experiments will be prepared based on preliminary experiments with different oil/emulsifiers and coordinated with the bench-scale testing effort.

Table A.3. Experimental Conditions for Soil Columns

\begin{tabular}{|c|c|c|c|c|c|c|}
\hline Treatment & $\begin{array}{l}\text { Amendments to } \\
\text { Groundwater }^{(a)}\end{array}$ & $\begin{array}{l}\text { Auto- } \\
\text { claved? }\end{array}$ & $\begin{array}{l}\text { Temper- } \\
\text { ature }\end{array}$ & Mode & Sediment & Groundwater \\
\hline 1 & $\begin{array}{l}\text { Fills 1-8: } 60 \mathrm{mg} / \mathrm{L} \\
\text { nitrate and } 1 \mathrm{mg} / \mathrm{L} \\
\text { chromate } \\
\text { Fill 9-12: } 20 \mathrm{mg} / \mathrm{L} \\
\text { nitrate and } 0.3 \mathrm{mg} / \mathrm{L} \\
\text { chromate }\end{array}$ & No & $18^{\circ} \mathrm{C}$ & $\begin{array}{l}\text { Fill and } \\
\text { Draw }\end{array}$ & $\begin{array}{l}\text { Composite } \\
\text { from } 100-\mathrm{D}, \\
<5 \mathrm{~mm} \text {, mixed } \\
\text { with substrate } \\
\text { at } 1 \mathrm{wt} \%\end{array}$ & $\begin{array}{l}\text { Uncontaminated } \\
\text { from 100-D, } \\
\text { equilibrated with } \\
\text { air, filter sterilized }\end{array}$ \\
\hline 2 & $\begin{array}{l}\text { Fills 1-8: } 60 \mathrm{mg} / \mathrm{L} \\
\text { nitrate }\end{array}$ & No & $18^{\circ} \mathrm{C}$ & $\begin{array}{l}\text { Fill and } \\
\text { Draw }\end{array}$ & $\begin{array}{l}\text { Composite } \\
\text { from } 100-\mathrm{D} \text {, } \\
<5 \mathrm{~mm} \text {, mixed } \\
\text { with substrate } \\
\text { at } 1 \mathrm{wt} \%\end{array}$ & $\begin{array}{l}\text { Uncontaminated } \\
\text { from 100-D, } \\
\text { equilibrated with } \\
\text { air, filter sterilized }\end{array}$ \\
\hline 3 & $\begin{array}{l}\text { Fills 1-8: } 1 \mathrm{mg} / \mathrm{L} \\
\text { chromate }\end{array}$ & No & $18^{\circ} \mathrm{C}$ & $\begin{array}{l}\text { Fill and } \\
\text { Draw }\end{array}$ & $\begin{array}{l}\text { Composite } \\
\text { from } 100-\mathrm{D}, \\
<5 \mathrm{~mm} \text {, mixed } \\
\text { with substrate } \\
\text { at } 1 \mathrm{wt} \%\end{array}$ & $\begin{array}{l}\text { Uncontaminated } \\
\text { from 100-D, } \\
\text { equilibrated with } \\
\text { air, filter sterilized }\end{array}$ \\
\hline $\begin{array}{c}4 \\
\text { (control) }\end{array}$ & $\begin{array}{l}\text { Fills 1-3: } 60 \mathrm{mg} / \mathrm{L} \\
\text { nitrate and } 1 \mathrm{mg} / \mathrm{L} \\
\text { chromate }\end{array}$ & No & $18^{\circ} \mathrm{C}$ & $\begin{array}{l}\text { Fill and } \\
\text { Draw }\end{array}$ & $\begin{array}{l}\text { Composite } \\
\text { from } 100-\mathrm{D}, \\
<5 \mathrm{~mm}\end{array}$ & $\begin{array}{l}\text { Uncontaminated } \\
\text { from 100-D, } \\
\text { equilibrated with } \\
\text { air, filter sterilized }\end{array}$ \\
\hline (control) & $\begin{array}{l}\text { Fills } 1-8: 60 \mathrm{mg} / \mathrm{L} \\
\text { nitrate, } 1 \mathrm{mg} / \mathrm{L} \\
\text { chromate, and } \\
200 \mathrm{mg} / \mathrm{L} \mathrm{NaN}_{3}\end{array}$ & Yes & $18^{\circ} \mathrm{C}$ & $\begin{array}{l}\text { Fill and } \\
\text { Draw }\end{array}$ & $\begin{array}{l}\text { Composite } \\
\text { from } 100-\mathrm{D}, \\
<5 \mathrm{~mm} \text {, mixed } \\
\text { with substrate } \\
\text { at } 1 \mathrm{wt} \%\end{array}$ & $\begin{array}{l}\text { Uncontaminated } \\
\text { from 100-D, } \\
\text { equilibrated with } \\
\text { air, filter sterilized }\end{array}$ \\
\hline 6 & None & No & $18^{\circ} \mathrm{C}$ & $\begin{array}{l}\text { Continuous } \\
\text { at } \\
0.1 \mathrm{~mL} / \mathrm{min} \\
\text { for } \\
\sim 20 \text { weeks }\end{array}$ & $\begin{array}{l}\text { Composite } \\
\text { from } 100-\mathrm{D} \text {, } \\
<5 \mathrm{~mm} \text {, mixed } \\
\text { with substrate } \\
\text { at } 1 \mathrm{wt} \%\end{array}$ & $\begin{array}{l}\text { Uncontaminated } \\
\text { from 100-D, } \\
\text { equilibrated with } \\
\text { air, filter sterilized }\end{array}$ \\
\hline $\begin{array}{c}7 \\
\text { (control) }\end{array}$ & None & Yes & $18^{\circ} \mathrm{C}$ & $\begin{array}{l}\text { Continuous } \\
\text { at } \\
0.1 \mathrm{~mL} / \mathrm{min} \\
\text { for } \\
\sim 20 \text { weeks }\end{array}$ & $\begin{array}{l}\text { Composite } \\
\text { from } 100-\mathrm{D}, \\
<5 \mathrm{~mm} \text {, mixed } \\
\text { with substrate } \\
\text { at } 1 \mathrm{wt} \%\end{array}$ & $\begin{array}{l}\text { Uncontaminated } \\
\text { from 100-D, } \\
\text { equilibrated with } \\
\text { air, filter sterilized }\end{array}$ \\
\hline
\end{tabular}




\section{A.2.2.3 Sediment and Groundwater Sampling Methods}

Filter sterilized groundwater will be collected in pre-sterilized polypropylene bottles. Two 20-L carboys (pre-sterilized) of filter sterilized groundwater will be collected for the continuous flow columns. Split-spoon sediment samples will be collected in pre-sterilized Lexan liners. The liners will be capped in the field, put in a cooler with ice, and transferred to the laboratory. Sediment and groundwater samples will be stored at $4^{\circ} \mathrm{C}$ until used in the tests. The small size fraction of the sediment samples will be composited under aseptic conditions prior to use in soil column tests.

\section{A.2.2.4 Test Methods}

For treatments requiring sediment mixed with oil/polylactate, a composite sample of sediment will be prepared. The oil and emulsifier or polylactate will be mixed with the sediment in an aseptic atmosphere with sterile equipment. The composite sediment and $1 \mathrm{wt} \%$ oil or polylactate will be mixed for use in experiments. Amended sediment will be used the same day for packing soil columns.

All soil columns will be prepared in an aseptic atmosphere (e.g., laminar flow hood). Sediment or sediment mixed with oil or polylactate will be wet packed by settling through sterile groundwater (see Appendix B) into 2.5-cm diameter, 30-cm-long pre-sterilized glass columns with porous end plates and fittings for injection and extraction tubing. The amount of sediment added to each column will be quantified by weighing the column filled with water and then filled with sediment and water. Porosity will be estimated based on a particle density of $2.5 \mathrm{~g} / \mathrm{mL}$. Killed controls will be constructed using sediment that has been autoclaved prior to mixing with oil or polylactate.

The fill process for soil columns in treatments 1 through 5 (Table A.3) will be conducted using a $100-\mathrm{mL}$ syringe filled with the appropriate amount of amendment solution to push $90 \mathrm{~mL}$ (or an amount determined based on the measured porosity) of solution through the column, taking into consideration the volume of tubing between the syringe and the column. The fill solution will be pushed in to the column at a rate of approximately $10 \mathrm{~mL} / \mathrm{min}$ manually using a syringe. The effluent from the soil columns will be configured to enable installation of tubing so that the effluent fills 5-mL syringes for sampling. Excess effluent collected will be disposed to a waste container. Soil columns will be incubated in the dark at $18^{\circ} \mathrm{C}$ and periodically sampled as described in the next section. This temperature was selected as representative of that for the 100-D Area aquifer.

Soil columns for treatments 6 and 7 (Table A.3) will be operated in continuous flow mode. After soil columns are packed, they will be connected to a flow through system consisting of a 20-L feed carboy filled with filter sterilized uncontaminated 100-D Area groundwater, a peristaltic pump capable of maintaining flow at $0.1 \mathrm{~mL} / \mathrm{min}$, and a 20 -L carboy used for effluent collection. The flow rate is equivalent to about $0.3 \mathrm{~m} / \mathrm{d}$, the average groundwater velocity in the area of the field site test cells. The effluent line will be configured to enable installation of tubing so that the effluent fills a 5-mL syringe for sampling. Components of the flow through system will be covered to minimize exposure of the fluid or sediment to light.

\section{A.2.2.5 Sampling and Analysis}

The soil columns will be sampled for the constituents per the schedules outlined in Table A.4. Before each fill event, a sample of the fill solution will be collected to confirm inlet conditions. Treatment 1 will 
be sampled nominally weekly, however, this schedule may be adjusted depending on the results of the first few sample events. Treatments 6 and 7 will be operated for 20 weeks.

Samples for dissolved oil or polylactate analysis by TOC will be collected by filling a 5-mL syringe with effluent. Samples for fermentation products will be collected by filling a $2.5-\mathrm{mL}$ syringe with effluent. For continuous-flow columns (treatments 6 and 7), the flow rate will be temporarily increased to $1 \mathrm{~mL} / \mathrm{min}$ during sampling for dissolved oil or polylactate. Samples will be frozen until analyzed for TOC. Fermentation product samples will be dispensed into a vial containing preservative. Samples will be analyzed by HPLC. All stock solutions will also be measured using the methods described above.

Table A.4. Sampling and Analysis Constituents and Schedule

\begin{tabular}{|c|c|c|c|}
\hline Treatment & Constituent & Schedule & $\begin{array}{c}\text { Destructive Sampling for Oil in } \\
\text { Sediment }\end{array}$ \\
\hline \multirow[t]{4}{*}{1} & $\begin{array}{l}\text { Dissolved oil or } \\
\text { polylactate }\end{array}$ & $\begin{array}{l}\text { Fill and effluent, } 1 \text { per week } \\
\text { fill/draw event }{ }^{\text {(a) }}\end{array}$ & NA \\
\hline & Nitrate, nitrite & $\begin{array}{l}\text { Fill and effluent, } 1 \text { per week } \\
\text { fill/draw event }{ }^{(\mathrm{a})}\end{array}$ & NA \\
\hline & Chromate & $\begin{array}{l}\text { Fill and effluent, } 1 \text { per week } \\
\text { fill/draw event }{ }^{(\mathrm{a})}\end{array}$ & NA \\
\hline & $\begin{array}{l}\text { Oil or polylactate } \\
\text { in sediment }\end{array}$ & NA & $\begin{array}{l}\text { Initial sample of sediment/oil mixture used } \\
\text { to fill the column, end of experiment }\end{array}$ \\
\hline \multirow[t]{3}{*}{2} & Dissolved oil & $\begin{array}{l}\text { Fill and effluent, } 1 \text { per week } \\
\text { fill/draw event }{ }^{(a)}\end{array}$ & NA \\
\hline & Nitrate, nitrite & $\begin{array}{l}\text { Fill and effluent, } 1 \text { per week } \\
\text { fill/draw event }{ }^{(\mathrm{a})}\end{array}$ & NA \\
\hline & $\begin{array}{l}\text { Oil or polylactate } \\
\text { in sediment }\end{array}$ & NA & $\begin{array}{l}\text { Initial sample of sediment/oil mixture used } \\
\text { to fill the column, end of experiment }\end{array}$ \\
\hline \multirow[t]{3}{*}{3} & $\begin{array}{l}\text { Dissolved oil or } \\
\text { polylactate }\end{array}$ & $\begin{array}{l}\text { Fill and effluent, } 1 \text { per week } \\
\text { fill/draw event }{ }^{(\mathrm{a})}\end{array}$ & NA \\
\hline & Chromate & $\begin{array}{l}\text { Fill and effluent, } 1 \text { per week } \\
\text { fill/draw event }{ }^{(\mathrm{a})}\end{array}$ & NA \\
\hline & $\begin{array}{l}\text { Oil or polylactate } \\
\text { in sediment }\end{array}$ & NA & $\begin{array}{l}\text { Initial sample of sediment/oil mixture used } \\
\text { to fill the column, end of experiment }\end{array}$ \\
\hline \multirow[t]{2}{*}{4} & Nitrate, nitrite & $\begin{array}{l}\text { Fill and effluent, } 1 \text { per week } \\
\text { fill/draw event }{ }^{\text {a) }}\end{array}$ & NA \\
\hline & Chromate & $\begin{array}{l}\text { Fill and effluent, } 1 \text { per week } \\
\text { fill/draw event }{ }^{(\mathrm{a})}\end{array}$ & NA \\
\hline \multirow[t]{4}{*}{5} & $\begin{array}{l}\text { Dissolved oil or } \\
\text { polylactate }\end{array}$ & $\begin{array}{l}\text { Fill and effluent, } 1 \text { per week } \\
\text { fill/draw event }{ }^{(\mathrm{a})}\end{array}$ & NA \\
\hline & Nitrate, nitrite & $\begin{array}{l}\text { Fill and effluent, } 1 \text { per week } \\
\text { fill/draw event }{ }^{(a)}\end{array}$ & NA \\
\hline & Chromate & $\begin{array}{l}\text { Fill and effluent, } 1 \text { per week } \\
\text { fill/draw event }{ }^{\text {(a) }}\end{array}$ & NA \\
\hline & $\begin{array}{l}\text { Oil or polylactate } \\
\text { in sediment }\end{array}$ & NA & $\begin{array}{l}\text { Initial sample of sediment/oil mixture used } \\
\text { to fill the column, end of experiment }\end{array}$ \\
\hline
\end{tabular}


Table A.4. (contd)

\begin{tabular}{|c|c|c|c|}
\hline Treatment & Constituent & Schedule & $\begin{array}{c}\text { Destructive Sampling for Oil in } \\
\text { Sediment }\end{array}$ \\
\hline \multirow[t]{2}{*}{6} & $\begin{array}{l}\text { Dissolved oil or } \\
\text { polylactate }\end{array}$ & 1 per week $^{(a)}$ & NA \\
\hline & $\begin{array}{l}\text { Oil or polylactate } \\
\text { in sediment }\end{array}$ & NA & $\begin{array}{l}\text { Initial sample of sediment/oil mixture used } \\
\text { to fill the column, end of experiment }\end{array}$ \\
\hline \multirow[t]{2}{*}{7} & $\begin{array}{l}\text { Dissolved oil or } \\
\text { polylactate }\end{array}$ & 1 per week $^{(a)}$ & NA \\
\hline & $\begin{array}{l}\text { Oil or polylactate } \\
\text { in sediment }\end{array}$ & NA & $\begin{array}{l}\text { Initial sample of sediment/oil mixture used } \\
\text { to fill the column, end of experiment }\end{array}$ \\
\hline \multicolumn{4}{|c|}{$\begin{array}{l}\text { (a) Fill/draw/sampling interval may be changed depending on initial rate of change. Effluent sample taken after } 2 \mathrm{ml} \text { has } \\
\text { been pushed out of the column for fill and draw. } \\
\mathrm{NA}=\text { Not applicable. }\end{array}$} \\
\hline
\end{tabular}

Samples for nitrate, nitrite and sulfur-based anions will be collected by filling a 5-mL syringe with effluent and dispensing into a vial containing preservative. Samples will be analyzed by ion chromatography. Samples for chromate will be collected by filling a $2.5-\mathrm{mL}$ syringe and dispensing into a vial containing preservative. Samples will be analyzed with a test kit (HACH model 5870017).

Destructive sampling and testing for oil or polylactate in sediment will be conducted by a gravimetric procedure (adapted from ASTM D2974-00, Standard Test Methods for Moisture, Ash, and Organic Matter of Peat and Other Organic Soils). In summary, samples will be heated to $105^{\circ} \mathrm{C}$ for 1 hour, cooled in a desiccator, and weighed to determine the dry weight (no water) of the sample. Samples will then be heated to $440^{\circ} \mathrm{C}$ for 16 hours, cooled in a desiccator and reweighed to calculate the weight of oil in the sample. A test of this method with a known amount of oil in sediment will be conducted to evaluate whether the expected accuracy of the method is suitable for the purpose of these experiments. Alternatively, the amount of oil will be assessed per the method described by Hunter (2001). A subsample from the destructive sediment sample will be used for ATP analysis of biomass using the same procedures described in Section A.2.1.5.

Data will be maintained both in an approved Laboratory Record Book and in Microsoft Excel.

\section{A.3 Facilities}

All tests will be conducted in the 331 Building.

\section{A.4 Hazards Assessment}

All procedures will be performed according to this test plan. There are no unusual hazards such as temperature, electrical, or radiation associated with this work. The primary hazard will be the use of small amounts of hazardous materials. Sections A.4 through A.9 of this test plan contain all the 
information normally included in a chemical safety protocol (CSP). Therefore, a separate CSP has not been written. Highlights of this safety information are the following:

- Chemicals will be used in small aliquots to reduce the chance for a large spill.

- Transfer of volatile or chemicals with inhalation hazards will be made in a fume hood.

- During transfer of a solution containing a hazard for skin contact, lab personnel will wear the following protective clothing: safety glasses, protective gloves (nitrile or polyvinyl alcohol), and a laboratory coat.

- This test plan will be posted in all laboratories within the 331 Building where work associated with the test plan is being conducted.

There are no unusual electrical, high-temperature, heavy equipment, chemical, or biological hazards associated with the test apparatus. Therefore, this test plan will be considered sufficient guidance to enable safe execution of these experiments by authorized project staff.

\section{A.5 Personnel Safety}

Staff working on this study will follow the guidance described in this section.

\section{A.5.1 Personnel Protective Equipment}

Laboratory personnel will wear the following protective clothing during transfer and handling of a solution containing a hazard for skin contact: safety glasses, protective gloves (nitrile or polyvinyl alcohol), and a laboratory coat.

\section{A.5.2 Material Safety Data Sheets}

The material safety data sheets (MSDS) for all chemicals are available to staff through the Pacific Northwest National Laboratory Standards-Based Management System (SBMS).

\section{A.5.3 Respiratory Protection Requirements}

Respiratory protection will be achieved by restricting the transfer and handling of pure chemicals to a chemical fume hood. Aqueous solutions of these compounds will be stored in sealed containers.

\section{A.5.4 Medical Requirements}

No special medical requirements are associated with this work.

\section{A.5.5 Confined Space}

There are no confined space issues associated with this work. 


\section{A.6 Waste Management}

All waste materials produced during these experiments will be disposed of properly by methods approved by PNNL Waste Management and Environmental Compliance. Chemical concentrations have been chosen to minimize the total amount of hazardous material required for completion of the experiments. All secondary waste will be collected in satellite accumulation areas. Once full, each satellite container will be transferred to the 90-day storage area. All containers contacting the chemicals will be triple rinsed with distilled water. Rinse water will be treated as waste. In the event of a spill, contaminated clothing and materials will be placed in a disposal can. Such cans will be stored in the satellite accumulation area until cleanup and disposal operations are completed. All waste will be moved out of the satellite accumulation area to the 90-day storage area within 72 hours after closing the project. All other cleanup operations will be completed within 2 weeks of the conclusion of the experiments.

\section{A.7 Associated Procedures and Safety Limits}

There are no procedures guiding this test other than this test plan.

\section{A.8 Quality Assurance}

This test will be conducted to be consistent with the project-specific QA requirements are provided in the project QA plan (PNNL 2007).

\section{A.9 Emergency Response}

Steps have been taken to eliminate the risk of a gross release by minimizing the amount chemicals used at any one time. In the unlikely event of a chemical spill, a spill kit located in each laboratory may be used for cleanup. Each spill kit contains absorbent material and plastic bags for containment of the absorbent. Personnel involved in the test program are required to familiarize themselves with the spill kit and procedures for cleanup. The spill container shall be sampled for the chemical compounds used in this experiment to determine its appropriate disposal method. Appropriate personal protective equipment will be used in the clean up. All spill cleanup materials will be designated and managed according to PNNL SBMS.

In the event of a spill involving contamination of personnel, skin contact areas will be immediately washed with soap and water in the nearest sink. The emergency eyewash and shower that are nearest each laboratory will be identified by project staff. Laboratory Safety will be notified immediately by calling 375-2400.

\section{A.10 References}

American Public Health Association. 1989. Standard Methods for the Examination of Water and Wastewater. 17th edition, American Public Health Association, Washington, D.C.

ASTM. 2006. Standard Test Methods for Moisture, Ash, and Organic Matter of Peat and Other Organic Soils. ASTM D2974-00, American Society for Testing and Materials, West Conshohocken, Pennsylvania. 
Coulibaly KM and RC Borden. 2004. "Impact of Edible Oil Injection on the Permeability of Aquifer Sands. J. Contam. Hydrol. 71:219-237.

Hunter WJ. 2001. "Use of Vegetable Oil in a Pilot-Scale Denitrifying Barrier. J. Contam. Hydrol. 53:119-131.

Hunter WJ. 2005. "Injection of Innocuous Oils to Create Reactive Barriers for Bioremediation:

Laboratory Studies." J. Contam. Hydrol. 80: 31-48.

PNNL. 2007. The Columbia River Protection Supplemental Technologies Quality Assurance Project Plan. PNNL-16340, Pacific Northwest National Laboratory, Richland, Washington. 


\section{Appendix B}

\section{Test Plan Summary}

Emulsion Formulation and Transport for 100-D Ringold Sediments 


\section{Contents}

B.1 Experimental Goals and Objectives .................................................................... B.

B.1.1 Emulsion Preparation and Initial Transport Assessment ...................................... B. B.

B.1.2 Emulsion Transport Studies ......................................................................... B.

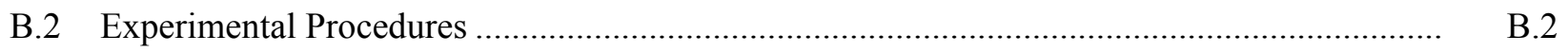

B.2.1 Emulsion Preparation and Initial Transport Assessment ….................................... B.

B.2.2 Emulsion Transport Studies ............................................................................... B.

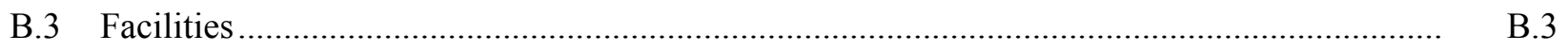

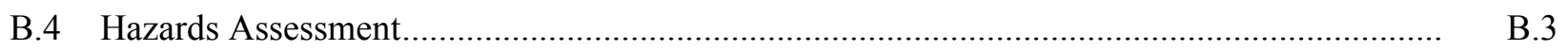

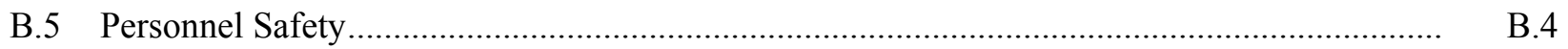

B.5.1 Personnel Protective Equipment …............................................................... B.4

B.5.2 Material Safety Data Sheets ........................................................................... B.

B.5.3 Respiratory Protection Requirements ............................................................... B. B.

B.5.4 Medical Requirements .............................................................................. B.

B.5.5 Confined Space .................................................................................. B. B...

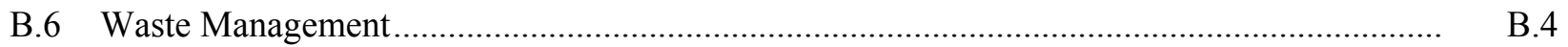

B.7 Associated Procedures and Safety Limits ….................................................................. B.

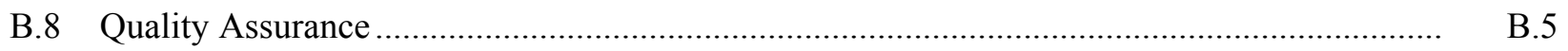

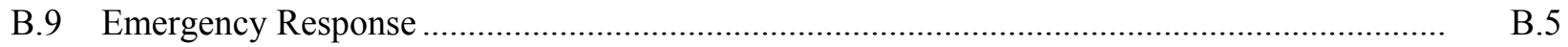

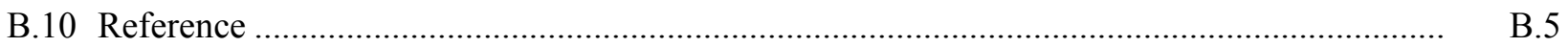

\section{Table}

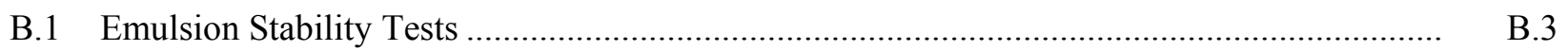




\section{Appendix B}

\section{B.1 Experimental Goals and Objectives}

The following laboratory tests are being conducted to support design of a field test for biostimulation as a means to create a reducing barrier for nitrate, chromate, and oxygen in the 100-D Area of the Hanford Site. This test plan summary outlines experimental approach associated with determining the emulsion properties and injection design for distributing vegetable oil into the subsurface.

\section{B.1.1 Emulsion Preparation and Initial Transport Assessment}

In addition to testing some of the experimental methods, the following questions will be investigated to determine appropriate emulsion formulations:

1. What are the droplet size, droplet size distribution, volumetric oil content, and uniformity of oil distribution of the emulsions produced from candidate substrate oils and emulsifiers?

2. For emulsion storage and handling, what is the stability and the nature of any observed coalescence over time for candidate emulsions in terms of changes in the uniformity of oil distribution, ability to remix to uniform emulsion distribution, ability to mix to decrease the volumetric oil content, buoyancy effects, temperature effects, and during flow through pipes, pumps, valves, and orifices?

3. Does the selected emulsion remain stable and transport/filter according to expectations in the experimental apparatus for the transport studies?

4. Do the experimental sampling and analysis methods provide suitable results for use in the transport studies?

\section{B.1.2 Emulsion Transport Studies}

The following questions will be investigated as part of assessing injection design and evaluating transport of emulsions in Ringold sediments.

1. How is transport and filtration of the selected emulsion material in uniform fine grain size sediments as measured by the distribution and magnitude of oil retention at injection and during redistribution a function of the following parameters?
a. Droplet size and size distribution
b. Sequenced or coincident injection of multiple emulsion droplet sizes
c. Volumetric oil content of emulsion
d. Injection velocity/flow rate
e. Post emulsion injection flushing

2. How is transport and filtration of the selected emulsion material in mixed silt-sand grain size sediments as measured by the distribution and magnitude of oil retention at injection and during redistribution a function of the following parameters?
a. Droplet size and size distribution
b. Sequenced or coincident injection of multiple emulsion droplet sizes 
c. Volumetric oil content of emulsion

d. Injection velocity/flow rate

e. Post emulsion injection flushing

3. How is transport and filtration of the selected emulsion material in Ringold sediments with a wide variation in particle sizes as measured by the distribution and magnitude of oil retention at injection and during redistribution a function of the following parameters?
a. Droplet size and size distribution
b. Sequenced or coincident injection of multiple emulsion droplet sizes
c. Volumetric oil content of emulsion
d. Injection velocity/flow rate
e. Post emulsion injection flushing

\section{B.2 Experimental Procedures}

The following procedures are designed to investigate the experimental goals and objectives.

\section{B.2.1 Emulsion Preparation and Initial Transport Assessment}

\section{Experimental Matrix}

A list of the emulsion preparations to be evaluated in this effort will be developed based on experience at other sites. Stability tests to be conducted for emulsions that meet the target droplet size and size distribution are listed in Table B.1. Preferred emulsion preparations from the testing described in Table B.1 will be tested in a soil column apparatus. The soil column test will be conducted using the protocols anticipated for using in the emulsion transport studies described in Section B.2.2 as a means to test these protocols and provide an initial evaluation of the emulsion transport.

\section{B.2.2 Emulsion Transport Studies}

\section{Experimental Matrix}

An experimental matrix will be developed to address the objectives described in Section B.1. Details related to the emulsion to be tested will be finalized based on the experiments described in Section B.2.1. Experimental apparatus details will also be finalized based on these initial results. In summary, the approach will use a combination of one-dimensional column experiments and wedge-shaped flow cells to examine emulsion transport and retention as a function of the key parameters that impact the injection design for the field test. The experimental apparatus and general approach will be similar to recently completed tests examining transport of zero-valent iron particles in Hanford sediments (e.g., Oostrom et al. 2005). 
Table B.1. Emulsion Stability Tests

\begin{tabular}{|c|c|c|c|c|}
\hline Test & Description & Temperature & Measurement & Criteria for Success \\
\hline 1 & $\begin{array}{l}\text { Storage stability: store emulsion } \\
\text { quiescently in a vessel with } \\
\text { periodic measurement of emulsion } \\
\text { properties and uniformity of oil } \\
\text { distribution after a moderate } \\
\text { remixing }\end{array}$ & $\begin{array}{l}\text { One treatment at } \\
\text { room } \\
\text { temperature and } \\
\text { one at } 35^{\circ} \mathrm{C}\end{array}$ & $\begin{array}{l}\text { Droplet distribution and } \\
\text { oil content in sample } \\
\text { taken from top of vessel } \\
\text { for comparison to } \\
\text { initial emulsion } \\
\text { properties }\end{array}$ & $\begin{array}{l}\text { Maintain oil droplet } \\
\text { size distribution over } \\
\text { 6-week period and } \\
\text { uniform oil } \\
\text { distribution with } \\
\text { moderate mixing }\end{array}$ \\
\hline 2 & $\begin{array}{l}\text { Mixing stability: dilute oil content } \\
\text { to } 50 \% \text { and } 25 \% \text { of initial oil } \\
\text { content with tap water in batch } \\
\text { system with moderate mixing }\end{array}$ & $\begin{array}{l}\text { Room } \\
\text { Temperature }\end{array}$ & $\begin{array}{l}\text { Droplet distribution and } \\
\text { oil content }\end{array}$ & $\begin{array}{l}\text { Maintain oil droplet } \\
\text { size distribution and } \\
\text { uniform oil } \\
\text { distribution }\end{array}$ \\
\hline 3 & $\begin{array}{l}\text { Flow stability: pump emulsion in } \\
\text { a recirculation loop into and out of } \\
\text { a small vessel with a centrifugal } \\
\text { pump through a piping system } \\
\text { with ball valves, tees, and reducers } \\
\text { and measure emulsion properties } \\
\text { periodically in the vessel. }\end{array}$ & $\begin{array}{l}\text { Room } \\
\text { Temperature }\end{array}$ & $\begin{array}{l}\text { Droplet distribution and } \\
\text { oil content }\end{array}$ & $\begin{array}{l}\text { Maintain oil droplet } \\
\text { size distribution and } \\
\text { uniform oil } \\
\text { distribution }\end{array}$ \\
\hline
\end{tabular}

\section{B.3 Facilities}

All tests will be conducted in the Environmental Molecular Science Laboratory's Subsurface Flow and Transport Laboratory.

\section{B.4 Hazards Assessment}

All procedures will be performed according to this test plan. There are no unusual hazards such as temperature, electrical, or radiation associated with this work. The primary hazard will be the use of small amounts of hazardous materials. Sections B.4 through B.9 of this test plan contain all the information normally included in a chemical safety protocol (CSP). Therefore, a separate CSP has not been written. Highlights of this safety information are the following:

- Chemicals will be used in small aliquots to reduce the chance for a large spill.

- Transfer of volatile or chemicals with inhalation hazards will be made in a fume hood.

- During transfer of a solution containing a hazard for skin contact, lab personnel will wear the following protective clothing: safety glasses, protective gloves (nitrile or polyvinyl alcohol), and a laboratory coat.

- This test plan will be posted in the laboratory where work associated with the test plan is being conducted.

There are no unusual electrical, high-temperature, heavy equipment, chemical, or biological hazards associated with the test apparatus. Therefore, this test plan will be considered sufficient guidance to enable safe execution of these experiments by authorized project staff. 


\section{B.5 Personnel Safety}

Staff working on this study will follow the guidance described in this section.

\section{B.5.1 Personnel Protective Equipment}

Laboratory personnel will wear the following protective clothing during transfer and handling of a solution containing a hazard for skin contact: safety glasses, protective gloves (nitrile or polyvinyl alcohol), and a laboratory coat.

\section{B.5.2 Material Safety Data Sheets}

The material safety data sheets (MSDS) for all chemicals are available to staff through the Pacific Northwest National Laboratory Standards-Based Management System (SBMS).

\section{B.5.3 Respiratory Protection Requirements}

Respiratory protection will be achieved by restricting the transfer and handling of pure chemicals to a chemical fume hood. Aqueous solutions of these compounds will be stored in sealed containers.

\section{B.5.4 Medical Requirements}

No special medical requirements are associated with this work.

\section{B.5.5 Confined Space}

There are no confined space issues associated with this work.

\section{B.6 Waste Management}

All waste materials produced during these experiments will be disposed of properly by methods approved by PNNL Waste Management and Environmental Compliance. Chemical concentrations have been chosen to minimize the total amount of hazardous material required for completion of the experiments. All secondary waste will be collected in satellite accumulation areas. Once full, each satellite container will be transferred to the 90-day storage area. All containers contacting the chemicals will be triple rinsed with distilled water. Rinse water will be treated as waste. In the event of a spill, contaminated clothing and materials will be placed in a disposal can. Such cans will be stored in the satellite accumulation area until cleanup and disposal operations are completed. All waste will be moved out of the satellite accumulation area to the 90-day storage area within 72 hours after closing the project. All other cleanup operations will be completed within 2 weeks of the conclusion of the experiments.

\section{B.7 Associated Procedures and Safety Limits}

There are no procedures guiding this test other than this test plan. 


\section{B.8 Quality Assurance}

This test will be conducted to be consistent with the project-specific QA requirements are provided in the project QA plan (PNNL 2007).

\section{B.9 Emergency Response}

Steps have been taken to eliminate the risk of a gross release by minimizing the amount chemicals used at any one time. In the unlikely event of a chemical spill, a spill kit located in each laboratory may be used for cleanup. Each spill kit contains absorbent material and plastic bags for containment of the absorbent. Personnel involved in the test program are required to familiarize themselves with the spill kit and procedures for cleanup. The spill container shall be sampled for the chemical compounds used in the experiment to determine its appropriate disposal method. Appropriate personal protective equipment will be used in the clean up. All spill cleanup materials will be designated and managed according to PNNL SBMS.

In the event of a spill involving contamination of personnel, skin contact areas will be immediately washed with soap and water in the nearest sink. The emergency eyewash and shower that are nearest each laboratory will be identified by project staff. Laboratory Safety will be notified immediately by calling 375-2400.

\section{B.10 References}

Oostrom M, TW Wietsma, MA Covert, and VR Vermeul. 2005. Experimental Study of Micron-Size Zero-Valent Iron Emplacement in Permeable Porous Media Using Polymer-Enhanced Fluids.

PNNL-15573, Pacific Northwest National Laboratory, Richland, Washington.

PNNL. 2007. The Columbia River Protection Supplemental Technologies Quality Assurance Project Plan. PNNL-16340, Pacific Northwest National Laboratory, Richland, Washington. 


\section{Appendix C}

\section{Use of Geophysical Methods for Monitoring}

Amendment Distribution: Background and Task 


\section{Contents}

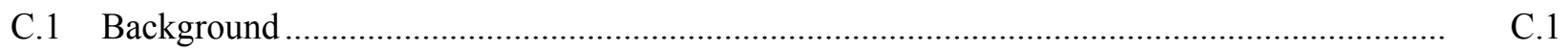

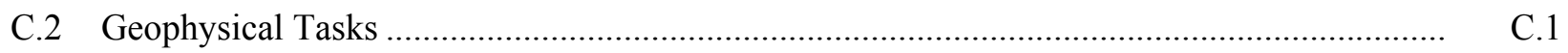

C.2.1 Geophysical Laboratory Studies ...................................................................... C.2

C.2.2 Geophysical Field-Scale Characterization and Monitoring ..................................... C. 3

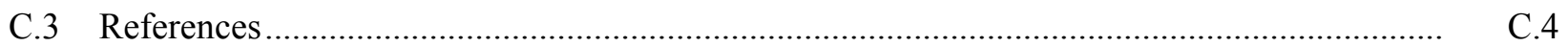

\section{Figure}

C.1 Subsurface Characterization and Monitoring of Amendment Distribution and Reactivity Using Crosshole Tomographic Data at the Hanford 100-H Site. 


\section{Appendix C}

\section{C.1 Background}

Fusion of geophysical data with direct measurements (hydrological, geochemical, microbiological) obtained through conventional sampling can enhance the ability of geophysical methods to estimate hydrogeological heterogeneity (e.g., Hubbard et al. 2001; Chen et al. 2006) and assess the role of heterogeneity on the efficacy of the remedial treatment (Hubbard et al. 2005, 2006). Recent work has investigated the sensitivity of various geophysical measurements to the injection of amendments and to the associated system transformations. These studies have included the use of Induced Polarization and acoustic methods to track changes in iron mineralogy during sulfate reduction at the laboratory scale (Williams et al. 2005a, 2005b; Ntarlagiannis et al. 2005), the use of radar and acoustic methods to detect the onset and evolution of gas at the laboratory and field scales (Williams et al. 2003), the use of radar and electrical methods for monitoring changes in pore fluid ionic strength at the laboratory and field scales (Hubbard et al. 2006), and the use of Spontaneous Potential (SP) measurements for characterization of redox conditions at the field scale (Williams et al. 2005c).

As an example, we conducted geophysical imaging in support of a $\mathrm{Cr}(\mathrm{VI})$ bioremediation effort at the 100-H Area at Hanford Site. For that test, $\mathrm{HRC}^{\mathrm{TM}}$, a slow-release polylactate compound, was injected into the Hanford formation to reduce and immobilize $\mathrm{Cr}(\mathrm{VI})$. Laboratory geophysical experiments were performed to assess the radar, seismic and electrical attribute responses to the key transformations that were expected to be detectable using geophysical methods, including the replacement of pore water with HRC, the replacement of pore water by evolved gases, the change in solute concentration, and the change in volume or concentration of solid phases. Field tomographic data were initially collected to characterize the hydraulic conductivities zonation in the injection region prior to designing the biostimulation experiment. Tomographic data were then collected over time and 'differenced' from the baseline datasets to elucidate the processes associated with the biostimulation.

The top image in Figure C.1 illustrates the hydraulic conductivity zonation in the stimulation zone obtained through fusion of borehole flowmeter and crosshole geophysical data. The subsequent images illustrate the changes in the estimated electrical conductivity as a function of time after HRC was injected into the aquifer; interpretations of these geophysical signatures based on comparison of the different geophysical datasets with wellbore measurements and on laboratory geophysical experiments. These data illustrate the utility of high-resolution geophysical methods for imaging the amendment distribution and reactivity as a function of heterogeneity.

\section{C.2 Geophysical Tasks}

In this project, the primary use of geophysical methods will be to assess the spatial distribution of the injected emulsified vegetable oil substrate at the field scale. However, geophysical methods will also be used to assist with the baseline (pre-injection) site-specific hydrogeological characterization and to assess the geophysical responses to immiscible substrates at the laboratory scale. These components are briefly discussed in the following sections. 


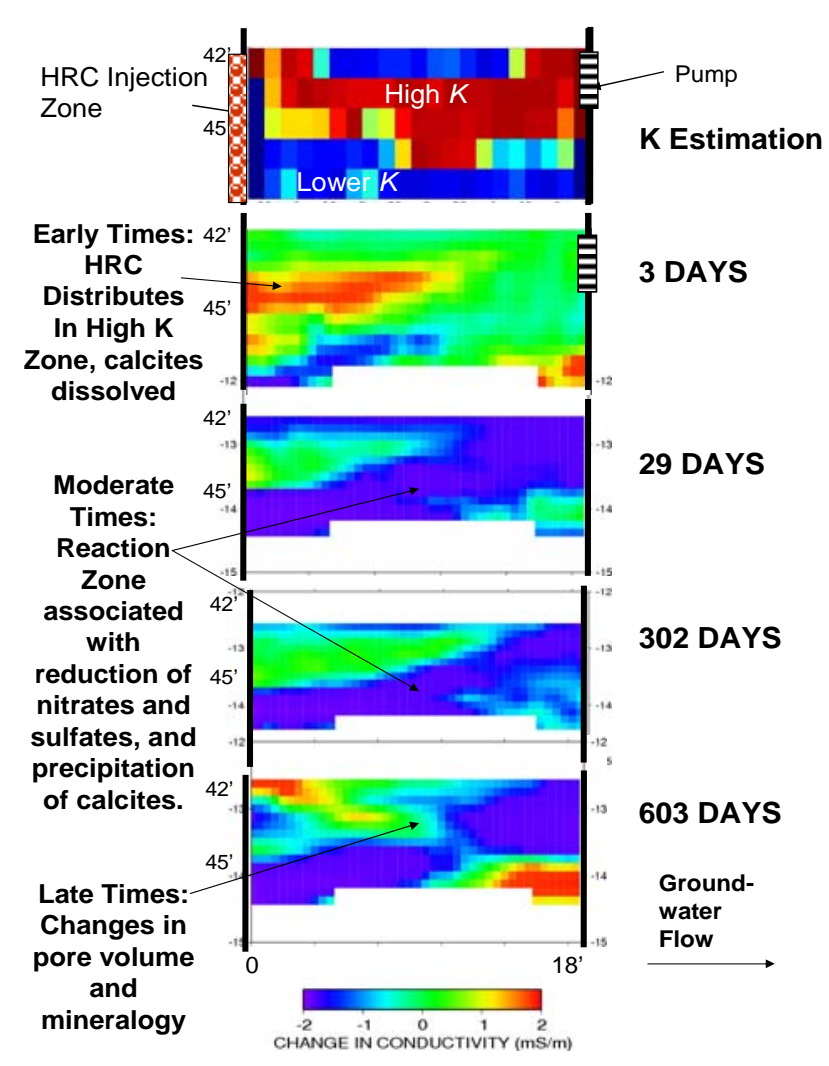

Figure C.1. Subsurface Characterization and Monitoring of Amendment Distribution and Reactivity using Crosshole Tomographic Data at the Hanford 100-H Area

\section{C.2.1 Geophysical Laboratory Studies}

Laboratory geophysical experiments will be performed to explore the sensitivities of multiple geophysical methods to pore water replacement by emulsified vegetable oil and associated products. Results of the laboratory experimentation will be used to guide the field-scale geophysical monitoring. We will perform a series of laboratory batch experiments to investigate the radar, acoustic, and electrical responses to the remediation processes that are expected to influence the geophysical signatures, such as the replacement of formation groundwater with amendment, the production of gases (such as methane or nitrogen), the change in solute concentration due to reductive processes, and changes in solids associated with the reductive processes.

For all experiments, parameters and materials will be chosen to best match field conditions. Timedomain reflectometers (TDR) acting in the low GHz range, Panametrics piezoelectric immersion transducers (with a central frequency of $1 \mathrm{MHz}$ ), and electrical conductivity meters will be used to measure radar, acoustic, and electrical resistivity responses, respectively. Based on the work of Lane et al. (2006), who described the increase in radar velocity associated with the injection of vegetable oil emulsion and on our previous experience, we expect that radar velocity, electrical conductivity, and seismic amplitudes measurements will be most sensitive to the amendment distribution; that radar velocity and seismic amplitudes will be most sensitive to gas production; that electrical resistivity and radar amplitudes will be most sensitive to the development or dissolution of precipitates and changes in total dissolved solids. 


\section{C.2.2 Geophysical Field-Scale Characterization and Monitoring}

The crux of the geophysical effort in this project will focus on field-scale monitoring during and after vegetable oil injection. We focus on monitoring the vegetable oil injection experiment only to constrain costs and because the wellbores associated with this experiment are close enough for testing several different types of geophysical monitoring approaches. Field-scale geophysical field monitoring includes the following three key tasks: 1) acquisition of appropriate time-lapse tomographic data, 2) inversion of the datasets, and 3) interpretation of the hydrogeological zonation as well as changes in geophysical attributes in terms of amendment distribution and system transformations through integration with direct measurements. These tasks are briefly discussed below:

- Acquisition. The methods that will be used for the time-lapse monitoring will be chosen based on laboratory results and wellbore type and availability, and may include tomographic seismic, radar, and electrical measurements. Electrical data will be collected using a Zonge GDP-32II/16 singlefunction receiver and ZT-30 transmitter ERT system, radar data will be collected using a PulseEKKO system with approximately $100 \mathrm{MHz}$ borehole antennas, and seismic data will be collected using a Lawrence Berkeley National Laboratory (LBNL) piezoelectric source and an ITI hydrophone sensor string. Baseline tomographic profiles will be collected prior to injection along six different transects that involve four different wells in the test cell. Subsequent tomographic profiles will be collected after injection only along selected transects, such as the transect downgradient from the injection zone and the transect perpendicular to groundwater flow. The spatial interval of the sensors in the wellbore will be $\sim 0.25 \mathrm{~m}$. The temporal interval of measurement acquisition is expected to be prior to injection (baseline), as well as approximately 1, 15, and 90 days post-injection (although this schedule may be modified based on results of the treatment bench-scale tests and field baseline characterization efforts).

- Inversion. If collected at the field scale, inversion of the radar and seismic data for seismic velocity, seismic attenuation, radar velocity, and radar attenuation will be made using protocols developed at LBNL (e.g., Peterson et al. 1985; Peterson 2001). Following Peterson (2001), where appropriate, inversion of 'differences' will be performed rather than differencing of sequential inversion results. Inversion of the electrical data will be made following Kemna (2000).

- Interpretation. After inversion, the field geophysical attribute estimates will be used to provide fieldscale characterization and monitoring of the biostimulation experiment. The distribution of the baseline geophysical attributes will be compared with flowmeter and core data to qualitatively assess hydrogeological zonation in the injection area. This information will be used to refine the emulsified vegetable oil injection plan. Interpretation of the spatiotemporal distribution of the injected amendment and associated products will be made based on the changes in the geophysical attributes relative to the baseline dataset, borehole geochemical analysis, and results from the laboratory testing.

As is illustrated by Figure C.1, we anticipate that the geophysical monitoring should help elucidate the understanding of the field-scale distribution of the injected amendments and associated transformations at the 100-D biostimulation site. 


\section{C.3 References}

Chen J, S Hubbard, J Peterson, K Williams, M Fienen, P Jardine, and D Watson. 2006. "Development of a Joint Hydrogeophysical Inversion Approach and Application to a Contaminated Fractured Aquifer." Water Resour. Res., 42, W06425, doi:10.1029/2005WR004694.

Hubbard S, J Chen, J Peterson, E Majer, K Williams, D Swift, B Mailliox, and Y Rubin. 2001. "Hydrogeological Characterization of the D.O.E. Bacterial Transport Site in Oyster Virginia Using Geophysical Data.” Water Resources Research 37(10):2431-2456.

Hubbard S, J Peterson, J Chen, KH Williams, M Conrad, B Fabishenko, P Long, A Willett, and T Hazen. 2005. "Geophysical Monitoring of Cr(VI) Bioreduction at the Hanford 100H Site." American Geophysical Union, Fall Meeting 2005, Abstract \#H44C-03, American Geophysical Union, Washington, D.C.

Hubbard SS, KH Williams, A Kemna, J Chen and J Peterson. 2006. Use of Geophysical Methods to Investigate, Guide, and Assess Contaminant Remediation Approaches. Invited Presentation for Session GSA T88, GSA Abstracts with Programs, 38(7).

Kemna A. 2000. Tomographic Inversion of Complex Resistivity: Theory and Application. Der Andere, Osnabrück, Germany.

Lane JW, F Day-Lewis, and C Casey. 2006. "Geophysical Monitoring of a Field-Scale Biostimulation Pilot Project." Ground Water 44(3):430-444.

Ntarlagiannis D, KH Williams, L Slater, and S Hubbard. 2005. "The Low Frequency Response to Microbial Induced Sulfide Precipitation.” J. Geophys. Res. 110(G2):G02009, 10.1029/2005JG000024.

Peterson JE Jr, BNP Paulsson, and TV McEvilly. 1985. "Applications of Algebraic Reconstruction Techniques to Crosshole Seismic Data." Geophysics 50:1566-1580.

Peterson JE Jr. 2001. "Pre-Inversion Corrections and Analysis of Radar Tomographic Data." Journal of Environmental and Engineering Geophysics 6:1-18.

Reppert PM. 2006. “Geophysical Investigation of the In Situ Redox Manipulation Barrier." Report for Fluor Hanford, Contract 25815.

Williams KH. 2003. Monitoring Microbe-Induced Physical Property Changes using High-Frequency Acoustic Waveform Data: Toward the Development of a Microbial Megascope. MS Thesis, University of California, Berkeley.

Williams KH, D Ntarlagiannis, LD Slater, A Dohnalkova, SS Hubbard, and JF Banfield. 2005a. "Remote Sensing of Stimulated Microbial Biomineralization.” Environmental Science \& Technology 39(19):7952-7600.

Williams KH, P Long, E Shelobolina, S Hubbard, and JF Banfield. 2005b. Non-Invasive Geophysical Monitoring of Microbe-Mediated Clay-Mineral Transformations. ISSM, Jackson Hole, Wyoming. 
Williams K, S Hubbard, and J Banfield. 2005c. "Monitoring Microbial Chemotaxis and Sulfate Reduction using the Self-Potential Method.” Eos Trans. AGU 86(18), Jt. Assem. Suppl., Abstract NS51B-07. 


\section{Appendix D}

\section{Drilling and Well Completion Plan 100-D Area Biostimulation Treatability Test}

Excerpted from Fluor Hanford, Inc.-developed drilling Statement of Work 


\section{Contents}

D.1 Introduction / Background ................................................................................... D.

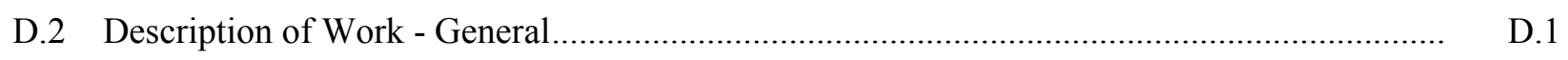

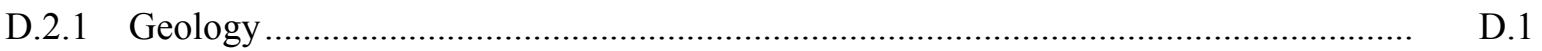

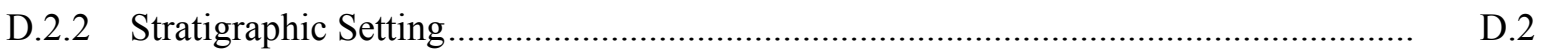

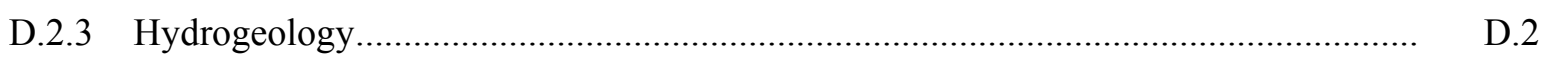

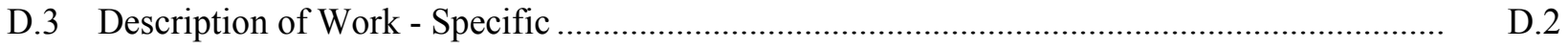

D.3.1 Drilling and Well Construction - General Requirements …................................. D. D

D.3.2 Sampling Requirements ........................................................................... D. D

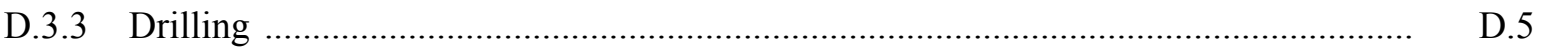

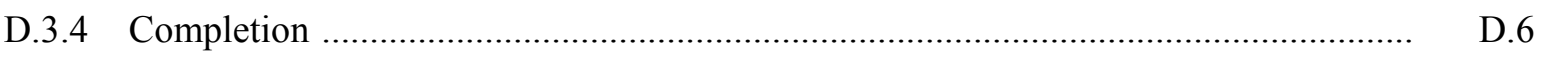

D.3.5 Final Well Development ….......................................................................... D. D

\section{Figures}

D.1 Location Map for 100-D Area Biostimulation Test Wells............................................... D.

D.2 Well Design for 100-D Area Biostimulation Treatment and Monitoring Wells..................... D.9

\section{Table}

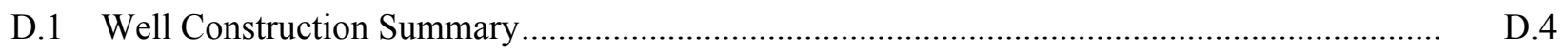




\section{Appendix D}

\section{D.1 Introduction/Background}

The Hanford Site covers approximately 586 square miles. Past nuclear weapon production activities at the site resulted in approximately 1.7 trillion liters (450 billion gallons) of liquid waste being released to the ground. Much of the associated contaminants remain in the vadose zone, between the top of the water table and the surface of the ground, but some have reached the groundwater. Hazardous chemical contaminants include carbon tetrachloride, chromium, and nitrates. Radioactive contaminants include iodine-129, strontium-90, technetium-99, tritium, and uranium. The U.S. Department of Energy, the U.S. Environmental Protection Agency, and the Washington State Department of Ecology have developed a remediation plan for protecting the Columbia River Corridor. The Groundwater Remediation Project is largely responsible for ensuring the plan is implemented.

The contractor shall mobilize to provide the equipment, material, and skilled labor to construct a minimum 8 to a maximum of 12 groundwater monitoring wells (C5577-C5588) to support a PNNL biostimulation treatability test to evaluate chromium removal technology at the Hanford Site. All wells included in this scope shall be located within the 100-D Area of the Hanford Site. This investigation will occur within the boundaries of the groundwater 100-HR-3 Operable Unit (OU). The majority of boreholes will be drilled to the top of the Ringold upper mud and screened across the entire saturated interval. The proposed well locations are shown in Figure D.1.

\section{D.2 Description of Work - General}

The contractor shall drill, complete, develop, and support associated sampling activities at a minimum of 8 and a maximum of 12 groundwater monitoring wells during this work scope. Location surveys and excavation permits have been completed for 12 well sites. As depicted in Figure D.1, the wells will be located within the area west of the 100-D Area fence line, between existing well 199-D5-40 and 199-D4-20. This area has relatively flat terrain and the depth to groundwater and expected total depth should not vary significantly between wells.

The proposed drilling method must have the capacity to drill through very coarse gravels and occasional boulders with sufficient borehole size to allow completion of two 6-in. diameter and up to ten 4-in. diameter wells. Cable-tool drilling methods are specified.

\section{D.2.1 Geology}

This section summarizes the general stratigraphy in the area surrounding the three new wells. Local geology has been described in detail in several documents, including the following:

- WCH-SD-EN-TI-011, Geology of the Northern Part of the Hanford Site: An Outline of Data Sources and the Geologic Setting of the 100 Areas.

- BHI-00184, Miocene -to Pliocene-Aged Suprabasalt Sediments of the Hanford Site, South-Central Washington.

- WHC-SD-EN-TI-132, Geologic Setting of the 100-HR-3 Operable Unit, Hanford Site, South-Central Washington. 


\section{D.2.2 Stratigraphic Setting}

The stratigraphy of the 100-HR-3 OU is consistent with other general Hanford Site descriptions. Unconsolidated sedimentary deposits overlie older basalt/basalt-related volcanic and sedimentary rock. The principal stratigraphic units of the Hanford Site are, from youngest to oldest, as follows:

- Holocene surficial deposits

- Pleistocene Hanford formation sediments

- Miocene-Pliocene Ringold Formation sediments

- Miocene Columbia River Basalt Group and interbedded Miocene Ellensburg Formation sediments.

The following description of the local stratigraphy is based on the geologic logs from the monitoring wells in the surrounding area. All depths and thicknesses are estimates and may vary due to the nature of the depositional/erosional environment along the riverbank and fluctuations in the water table.

All wells will be drilled within the project area (Figure D.1) west of the 100-D Area. The Hanford formation is present immediately beneath the backfill/disturbed surface sediments. The Hanford formation is a Pleistocene-age, cataclysmic flood, and inter-flood deposit comprised of clast-supported, unconsolidated sandy gravels to gravelly sands, with occasional intercalated silt and sand stringers. The Hanford formation in the project area is expected to extend to approximately $50 \mathrm{ft} \mathrm{bgs.}$

Hanford formation sediments overlie the fine-to-coarse sediments of the Miocene to Pliocene Ringold Formation. The Ringold Formation is primarily composed of fluvially derived sand and gravel. The Ringold Formation Unit $\mathrm{E}$ at the project location consists of coarse-grained sands and gravels with a varying degree of cementation. The thickness of the Ringold Formation Unit E in the project area is estimated to be in the range of $50 \mathrm{ft}$. The estimated bottom of the Ringold Unit E is $100 \mathrm{ft}$ bgs. Underlying the Ringold Unit $\mathrm{E}$ is a fine-grained facies of the Ringold Formation referred to as the Ringold upper mud unit. The top of the Ringold upper mud unit is the target drill depth for all of the boreholes included in this work scope. The Ringold upper mud is characterized in area wells as pale brown to brown silt and clay.

\section{D.2.3 Hydrogeology}

The vadose zone at the project location is composed of backfill material and sands, gravels, and boulders of the Hanford formation. The unconfined aquifer beneath the project area is found within the lower Hanford and the entire Ringold Formation Unit E. The bottom of the unconfined aquifer in the project area is defined by the Ringold upper mud unit. The depth to groundwater is approximately $82 \mathrm{ft}$ bgs and the saturated interval is approximately 20 - $\mathrm{ft}$ thick in the project area.

\section{D.3 Description of Work - Specific}

\section{D.3.1 Drilling and Well Construction - General Requirements}

The drilling contractor will be responsible for complying with well drilling and construction standards as defined by the requirements of the "Master Drilling Contract," Section 4.1, including WAC 173-160, "Minimum Standards for Construction and Maintenance of Wells." The drilling equipment will be adequately sized to allow the wells to be a minimum diameter of 4-in. larger than the nominal size of the 
surface casing per WAC 173-160-231. The drill rig and all down-hole equipment will be high temperature/pressure washed prior to use and between wells to minimize potential cross-contamination. The two central injection wells will be completed with 6-in. diameter polyvinyl chloride (PVC) continuous wire-wrap screen and riser pipe. The remaining 8 to 10 monitoring wells will be completed with 4-in. diameter PVC continuous wire-wrap screen and riser (Note: Slotted screen is not an acceptable alternative to continuous wire-wrap screen and shall not be used in these wells). The final total depth of the boreholes is targeted for the Ringold upper mud (approximately $110 \mathrm{ft} \mathrm{bgs}$ ), except for two shallow monitoring wells targeted for $\sim 93$-ft total depth, but may change depending on the hydrogeologic conditions encountered. The final drill and completion depths will be determined by the Fluor Hanford, Inc. $\mathrm{FH}(\mathrm{FH})$ field geologist and $\mathrm{FH}$ project manager.

The boreholes will be drilled to provide vadose zone and groundwater characterization data, and the wells will be constructed to provide groundwater monitoring and water level data. The general well design is shown in Figure D.2. The wells will be constructed with 6-in.(for the two injection wells) and 4-in. (for the 8-10 monitoring wells) diameter, flush-joint, threaded, Schedule 40, PVC, 0.020-in. (20-slot) continuous wire-wrap screen atop a 6-in. long Schedule 40 PVC end cap. The flush-joint, threaded, riser casing extending to the surface will be of the same material (i.e., Schedule 40, PVC). The screen interval for the injection and standard monitoring wells will be $25-\mathrm{ft}$ long and will be set at a depth to be determined based on the historic water level trends in well 199-D5-40 and relative ground surface elevation at the drill location for each well. PNNL staff shall confirm these depths prior to placing the screen in each well. Four wells will have 5-ft long screens. Final placement of the well screen will be at the direction of the Buyer's Technical Representative (BTR) and/or FH field geologist. See Figure D.2 for well construction details. Well screen installation will begin after groundwater analytical results for contaminant concentrations are available.

The filter pack will consist of 10-20 mesh Colorado silica sand and will extend to approximately $2 \mathrm{ft}$ above the top of the screen. The actual completed screened intervals for these wells, as well as the associated filter pack configuration, will be determined based on the historical water table elevation in well 199-D5-40 and adjusted to the elevation of the well under construction. The well casing/screen string must be maintained in tension during the sand pack installation (i.e., the string weight is suspended from the top and is not allowed to rest on the bottom of the borehole) to maintain straightness of the completed well.

A 1.5-ft layer of bentonite pellets will be placed directly on top of the filter pack. Bentonite crumbles will be used to seal the remaining borehole to $3 \mathrm{ft} \mathrm{bgs}$. The deep monitoring wells with 5 - $\mathrm{ft}$ long screens will have secondary pellets seals above the screen, and will be backfilled with coarse sand to above the static water level.

A surface seal of cement grout will be installed from $10 \mathrm{ft}$ bgs to ground surface. This surface-seal specification, a deviation from the $18 \mathrm{ft}$ requirement in WAC 173-160, is based on a waiver received from Ecology for groundwater monitoring wells installed on the Hanford Site (documented in August 1998 meeting minutes for Hanford Site Ground Well Drilling and Decommissioning Activities). The surface construction consisting of protective casing, protective guard posts, and cement pad must be emplaced prior to final well development.

Table D.1 provides a summary of well construction parameters for these wells, including the estimated water levels, well depths, screen intervals, filter-pack and secondary filter pack sand intervals, and cement-seal intervals. 
Table D.1. Well Construction Summary

\begin{tabular}{|c|c|c|c|c|c|c|c|c|c|}
\hline $\begin{array}{l}\text { Well Number } \\
\text { /Purpose }\end{array}$ & $\begin{array}{c}\text { Estimated } \\
\text { Depth to } \\
\text { Water } \\
\text { (ft bgs) }^{(a)}\end{array}$ & $\begin{array}{c}\text { Planned } \\
\text { TD } \\
\text { (ft) }^{(b)}\end{array}$ & $\begin{array}{c}\text { Screen } \\
\text { and } \\
\text { Casing } \\
\text { Diameter } \\
\text { (in.) }\end{array}$ & $\begin{array}{l}\text { Screen } \\
\text { Slot Size }\end{array}$ & $\begin{array}{c}\text { Screen } \\
\text { Length }^{(b)} \\
\text { (ft)/ } \\
\text { Interval } \\
\text { (ft bgs) }\end{array}$ & $\begin{array}{c}\text { Filter } \\
\text { Pack } \\
\text { Mesh/ } \\
\text { Interval } \\
\text { (ft bgs) }\end{array}$ & $\begin{array}{c}\text { Sand } \\
\text { Backfill } \\
\text { Interval } \\
\text { (ft bgs) }\end{array}$ & $\begin{array}{l}\text { Bentonite } \\
\text { Pellet Seal }\end{array}$ & $\begin{array}{c}\text { Bentonite } \\
\text { Seal } \\
\text { Interval } \\
\text { (ft bgs) }\end{array}$ \\
\hline Injection Wells C5577,C5578 & 82 & 112 & 6-in. PVC & 20 & $\begin{array}{c}25 \\
85-110\end{array}$ & $\begin{array}{c}\text { TBD } \\
83-112\end{array}$ & NA & $77-83$ & $10-77$ \\
\hline Standard Monitoring Wells & 82 & 112 & 4-in. PVC & 20 & $\begin{array}{c}25 \\
85-110\end{array}$ & $\begin{array}{l}\text { TBD } \\
83-112\end{array}$ & NA & $77-83$ & $10-77$ \\
\hline Shallow Monitoring Wells C5582, C5587 & 82 & 94 & 4-in. PVC & 20 & $\begin{array}{c}5 \\
87-92\end{array}$ & $85-94$ & NA & $77-85$ & $10-77$ \\
\hline $\begin{array}{l}\text { Deep Monitoring Wells } \\
\text { C5583, C5588 }\end{array}$ & 82 & 106 & 4-in. PVC & 20 & $\begin{array}{c}5 \\
100-105\end{array}$ & $98-106$ & $80-92$ & $\begin{array}{l}92-98 \\
77-80\end{array}$ & $10-82$ \\
\hline \multicolumn{10}{|c|}{$\begin{array}{l}\text { TD }=\text { Total depth. } \\
\text { TBD }=\text { To be determined. } \\
\text { (a) Estimated depth to water taken from previously drilled wells. } \\
\text { (b) Planned TD and intervals may be modified after evaluation of characterization and drilling data. Nominal depths based on surface elevation at existing } \\
\text { well 199-D5-40. }\end{array}$} \\
\hline
\end{tabular}


Final well development with a submersible pump will occur after each well is constructed. During final well development, water samples will be collected and analyzed for chemical and physical parameters ( $\mathrm{pH}$, temperature, specific conductivity, and turbidity) using field instruments. A data logger will record pressure transducer water-level measurements during the drawdown and recovery phases of the final well development. Well development is considered complete after groundwater parameters have stabilized and turbidity samples are measured at or below 50 nephelometric turbidity units (NTU). This higher tolerance for turbidity (generally specified as less than 5 NTU) was specified to keep the drilling contract cost down. The drilling contractor will perform the initial development and remove most of the fines that will be generated by the well. If required, additional developmental pumping will be conducted as part of the monitoring systems setup and testing after dedicated sampling pumps have been installed. All site monitoring wells will be developed adequately to meet treatability test requirements prior to conducting the test.

An Environmental Radiological Survey Task Instruction will be prepared for this project to provide Radiological Control Technicians with directions for surveying the removed soil. As this well is considered to have a low risk for encountering appreciable concentrations of radioactivity, a Radiation Work Permit is not anticipated but will be developed if needed. In the event that radiological contamination is detected by field instruments or perched water is encountered, work will be stopped and appropriate radiological control documents will be prepared. If chemical contamination is encountered, work shall be stopped immediately, the FH Buyer's Technical Representative will be contacted, and an appropriate chemical monitoring plan will be prepared by FH.

Drilling at all well locations is considered a low radiological risk activity.

\section{D.3.2 Sampling Requirements}

Sampling requirements for all wells include collecting routine archive grab samples (one-pint jars) and chip tray samples of drill cuttings at 5-ft intervals and at changes in lithology (i.e., Hanford formation - Ringold Formation boundary and Ringold Formation Unit E, and upper mud boundary). Continious split spoons will be collected in new contractor-supplied 6-in.-long, 4-in.-diameter clean Lexan liners, using a buyer-supplied split-spoon sampler from approximately static water level to total depth (82 $110 \mathrm{ft}$ bgs) in the two injection wells, C5577 and C5578. Split-spoon samplers and liners will be field decontaminated by the buyer with ethanol before use.

If drill cuttings in the vadose zone of any well show a distinct discoloration, these cuttings will be collected for analysis.

Borehole Geophysical Logging is not required for this project.

\section{D.3.3 Drilling}

The Contractor shall be responsible for the following drilling activities:

A. The Contractor shall advance the boreholes in accordance with this contract to the depth required and install the specified length of screen below the static water level as determined by FH field geologist. Expected total depths are specified in Section D3. 
B. Collect soil and groundwater samples as required. Personnel handling any portion of the split-spoon sampler and/or Lexan liners shall wear clean, new latex gloves.

C. Follow sampling requirements as outlined in Section D3. Groundwater samples will be collected in accordance with GRP-EE-01-4.1, "Groundwater Sampling."

D. Perform a straightness test prior to installing the well casing and screen. The test shall be conducted by lowering a $20-\mathrm{ft}$-long section of pipe that is 2 -in. smaller in diameter than the inner diameter of the temporary casing to the bottom of the boring. The $20-\mathrm{ft}$ pipe must freely pass to the total depth of the boring to be considered a successful test.

\section{D.3.4 Completion}

The Contractor is responsible for procuring and installing all permanent material in accordance with this contract. Final determination of well completion material and filter-pack installation depth is determined by the FH field geologist's interpretation of downhole geologic conditions.

A. Set screen and permanent casing in wells. Personnel handling any portion of the permanent screen or casing that will be placed into the aquifer shall wear clean cotton or latex gloves.

B. The top of the screen will be set as determined by FH field geologist's water level measurements and surface elevation of the well being constructed (Table D.1).

C. Install and settle the filter pack using a dual-surge block method and bailing technique. The Contractor shall place and develop the filter pack in no greater than 10-ft intervals. As a general guide, if the filter pack in the annulus drops out at a rate of less than $0.1 \mathrm{ft}$ in 15 minutes, the interval is settled. Each interval must be surged for a minimum of 1 hour. Settling the filter pack is critical in the new wells.

D. Install 3/8-in. bentonite pellet seal.

E. Install bentonite crumbles seal.

F. Install $3 \mathrm{ft}$ of cement grout surface seal.

G. Install surface protection and brass survey marker. Surface protection shall be installed in accordance with WAC 173-160-420 with the following modifications:

1. The protective casing shall be a minimum of 2 in. larger in diameter than the permanent casing. This protective casing shall be made of Type 304 (or higher grade; e.g., 304L, 316, or 316L) stainless-steel.

2. The protective casing shall rise approximately $3 \mathrm{ft}$ above ground surface in the groundwater monitoring wells. The protective casing will be capped with a 15-in. lockable cap above the top of the protective casing and have inner tabs to fit plumb.

3. The permanent casing shall rise to approximately $2 \mathrm{ft}$ above ground surface and shall be approximately $1 \mathrm{ft}$ below the top of the protective casing in the groundwater monitoring wells. 
4. Concrete pads shall be 4-ft by 4-ft square by 6-in. thick and shall be steel reinforced with 6 -in. by 6-in. W1.4XW1.4 (metric wire gauge, approximately equivalent to 166 gauge) welded wire fabric as a minimum.

5. A brass survey marker with the well identification number, well name, and completion date inscribed shall be installed on the north side of the pad.

6. Four protective posts shall be placed around the concrete pad; each post shall be at least 3 in. in diameter. Three of the posts shall extend at least $3 \mathrm{ft}$ above and below ground and shall be cemented at least $3 \mathrm{ft}$ into the ground. The fourth post shall be removable for well access. Posts shall be located no more than $1 \mathrm{ft}$ from the corner of the concrete pad and painted yellow (ANSI Standard Z535.1 [ANSI 1991]). This surface protection shall meet the standards of WAC 173-160-420 (12) (a).

\section{D.3.5 Final Well Development}

A. Contractor shall perform final well development by pumping the well. Final development consists of pumping the well at a flow rate that ranges from 5 to 30 gallons per minute. During pumping, water samples will be collected for turbidity, temperature, $\mathrm{pH}$, and specific conductance analyses. Development will continue until the well temperature, $\mathrm{pH}$, and specific conductance have stabilized (at least three consecutive measurements within $10 \%$ of each other) and the well produces water with a turbidity of $<50$ NTU. Should these conditions not be met, the FH BTR, with the concurrence of the FH field geologist, shall determine when the development is adequate.

B. Buyer will provide a truck and driver to contain and transport purgewater to appropriate facility.

C. The development shall be performed in two stages on wells with 25 -ft long screens.

D. Contractor shall notify the FH BTR 24 hours prior to the anticipated final development time to arrange for purgewater transportation, hydrogeologic testing support, and other support necessary to implement final development.

E. Final well development shall not be started sooner than 12 hours following placement of the bentonite grout seal. Final well development shall not proceed until the cement pad and protective casing are established around the well.

F. The Contractor shall supply and install a temporary pump with check valve and all pumping equipment (e.g., generator, control box, tubing, and hose) necessary to develop the wells to required levels.

1. Contractor shall provide a submersible pump, flow meter, and all necessary support equipment capable of pumping 5-30 gallons per minute from groundwater monitoring wells. A flow meter capable of measuring flow rates from 1 to 30 gallons per minute must be available. The estimated well development time is approximately 2-4 hours.

2. Buyers' field geologist/hydrogeologist shall monitor drawdown by either transducer or by e-tape.

G. FH field geologist/hydrogeologist shall monitor aquifer response and monitor recovery time. During recovery monitoring, the pump and all downhole monitoring equipment shall remain in place. Recovery monitoring is expected to take at least 30 minutes per final development event. 


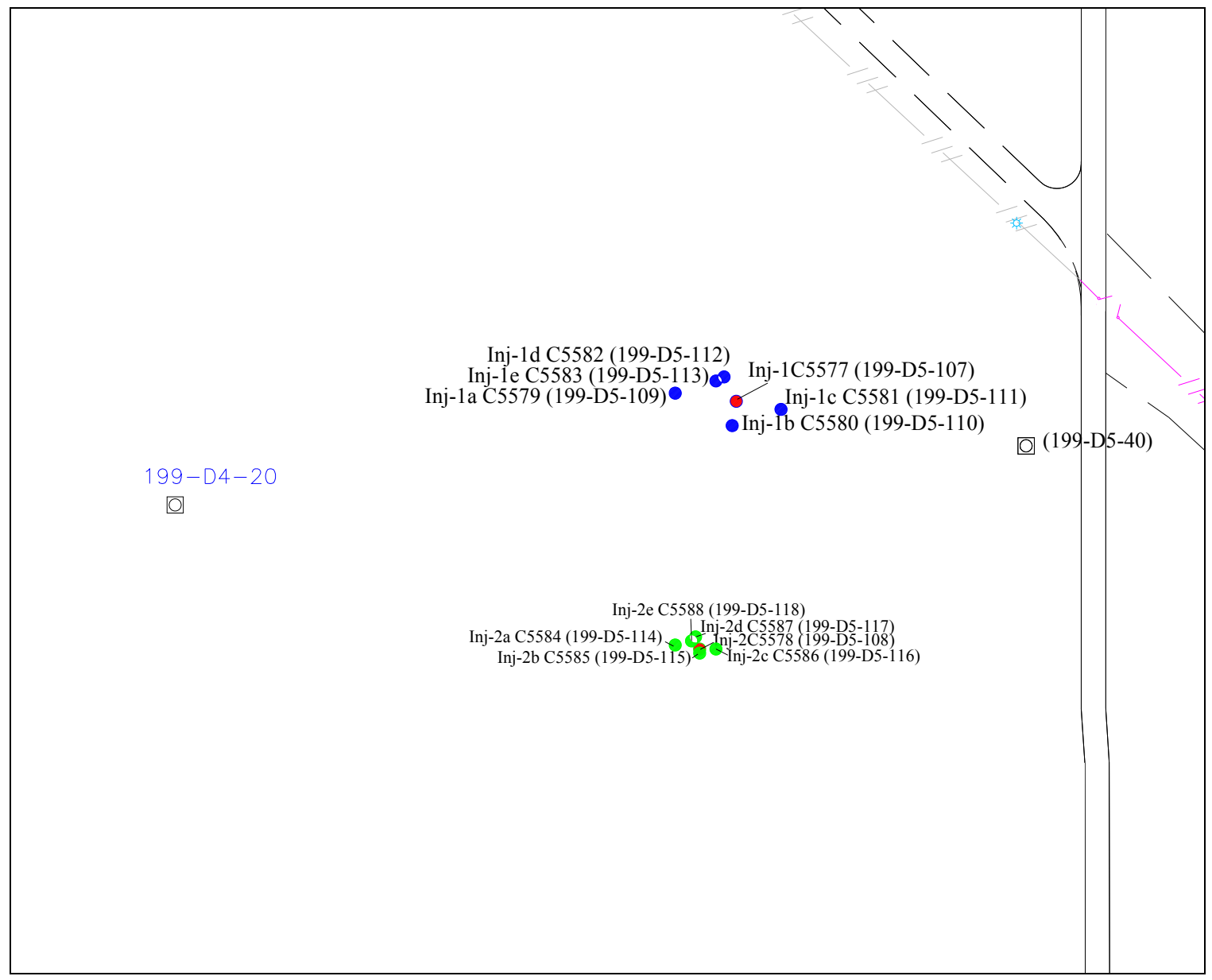

Figure D.1. Location Map for 100-D Area Biostimulation Test Wells 


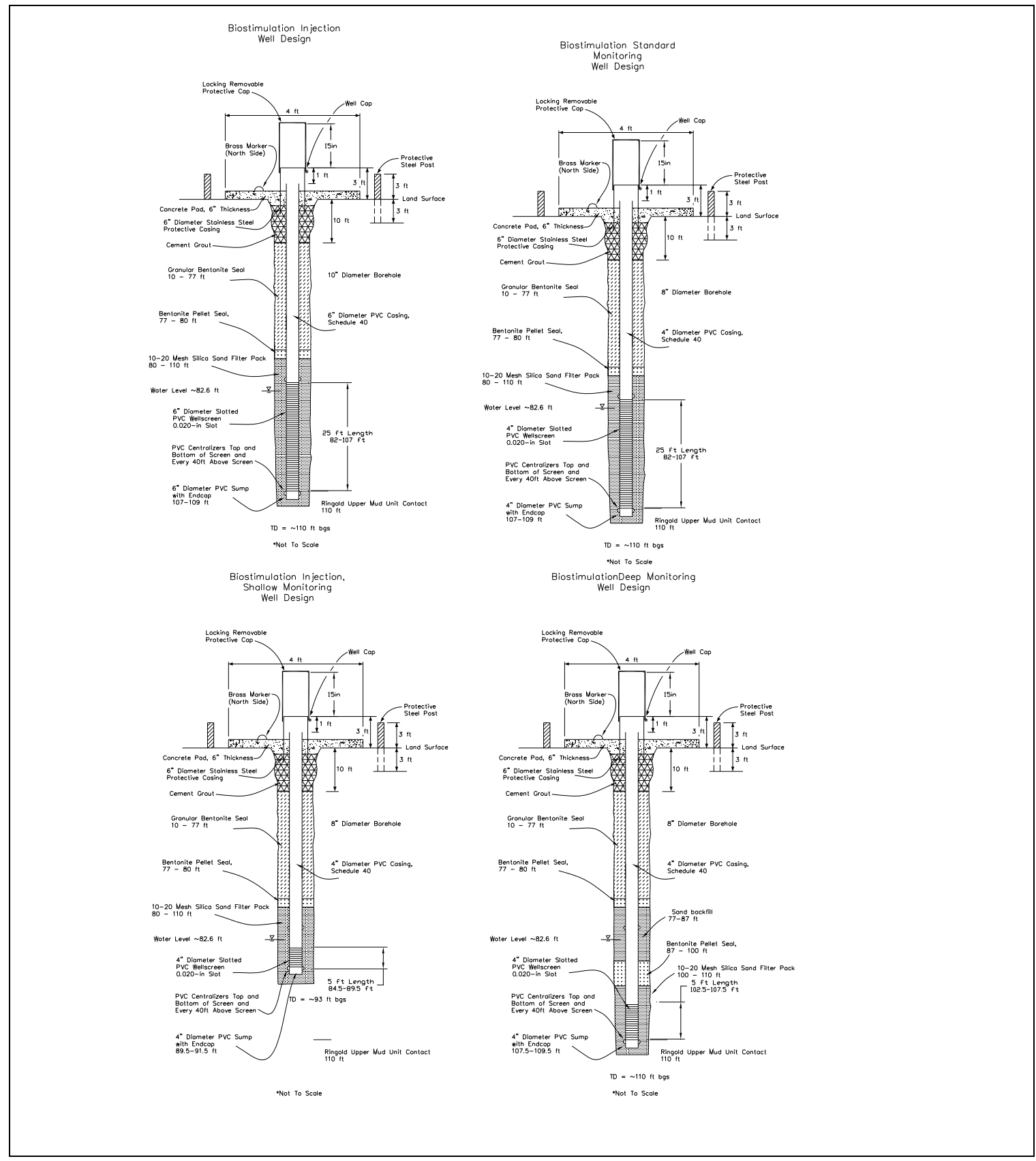

Figure D.2. Well Design for 100-D Area Biostimulation Treatment and Monitoring Wells 
PNNL-16424, Rev. 1

\section{Distribution}

No. of

Copies

U.S. Department of Energy

K.M. Thompson
No. of

Copies

6 Pacific Northwest National Laboratory

A6-38

J.S. Fruchter

K6-96

P.E. Long

K9-33

M.J. Truex

K6-96

V.R. Vermeul

K6-96

Hanford Technical Library (2) 